\title{
Conceptual Development of Immunotherapeutic Approaches to Gastrointestinal Cancer
}

\author{
Bilikis Aderonke Abolarinwa ${ }^{1}$, Ridwan Babatunde Ibrahim ${ }^{2,3}$ and \\ Yen-Hua Huang 1,4,5,6,7,8,9,10,* (D) \\ 1 International PhD Program for Cell Therapy and Regeneration Medicine, College of Medicine, Taipei \\ Medical University, Taipei 11031, Taiwan; Bekee02@gmail.com \\ 2 Institute of Brain Science, School of Medicine, National Yang-Ming University, Taipei 11221, Taiwan; \\ geniusridwan@gmail.com \\ 3 Taiwan International Graduate Program (TIGP) in Interdisciplinary Neuroscience, National Yang-Ming \\ University and Academia Sinica, Taipei 11529, Taiwan \\ 4 Department of Biochemistry and Molecular Cell Biology, School of Medicine, College of Medicine, Taipei \\ Medical University, Taipei 11031, Taiwan \\ 5 Graduate Institute of Medical Sciences, College of Medicine, Taipei Medical University, Taipei 11031, Taiwan \\ 6 TMU Research Center for Cell Therapy and Regeneration Medicine, Taipei Medical University, Taipei 11031, \\ Taiwan \\ 7 Center for Reproductive Medicine, Taipei Medical University Hospital, Taipei 11031, Taiwan \\ 8 Comprehensive Cancer Center of Taipei Medical University, Taipei 11031, Taiwan \\ 9 TMU Research Center of Cancer Translational Medicine, Taipei Medical University, Taipei 11031, Taiwan \\ 10 Ph.D. Program for Translational Medicine, College of Medical Science and Technology, Taipei Medical \\ University, Taipei 11031, Taiwan \\ * Correspondence: rita1204@tmu.edu.tw; Tel.: +886-2-2736-1661 (ext. 3150)
}

Received: 8 August 2019; Accepted: 16 September 2019; Published: 18 September 2019

\begin{abstract}
Gastrointestinal (GI) cancer is one of the common causes of cancer-related death worldwide. Chemotherapy and/or immunotherapy are the current treatments, but some patients do not derive clinical benefits. Recently, studies from cancer molecular subtyping have revealed that tumor molecular biomarkers may predict the immunotherapeutic response of GI cancer patients. However, the therapeutic response of patients selected by the predictive biomarkers is suboptimal. The tumor immune-microenvironment apparently plays a key role in modulating these molecular-determinant predictive biomarkers. Therefore, an understanding of the development and recent advances in immunotherapeutic pharmacological intervention targeting tumor immune-microenvironments and their potential predictive biomarkers will be helpful to strengthen patient immunotherapeutic efficacy. The current review focuses on an understanding of how the host-microenvironment interactions and the predictive biomarkers can determine the efficacy of immune checkpoint inhibitors. The contribution of environmental pathogens and host immunity to GI cancer is summarized. A discussion regarding the clinical evidence of predictive biomarkers for clinical trial therapy design, current immunotherapeutic strategies, and the outcomes to GI cancer patients are highlighted. An understanding of the underlying mechanism can predict the immunotherapeutic efficacy and facilitate the future development of personalized therapeutic strategies targeting GI cancers.
\end{abstract}

Keywords: gastrointestinal cancer; predictive biomarker; immunotherapy; immune system; tumor microenvironment

\section{Introduction}

Gastrointestinal cancer (GI) is one of the deadliest malignancies, accounting for 3.3 million deaths worldwide according to the 2018 Globocan report. Patients are often diagnosed at a late and advanced 
stage and thus have limited treatment options. Approximately $20-25 \%$ of patients develop metastasis during the course of the disease [1]. Despite a meaningful prognosis and targeted chemotherapies, the overall survival rate in these patients still remains low [2]. Immunotherapeutic strategies have been successfully used in the treatment of melanoma, non-small cell lung cancer (NSCLC), and hematological malignancies [3,4]. However, these treatments have yielded an undesirable objective response rate (ORR) between $10 \%$ and $25 \%$ in GI cancers [5]. Understanding the tumor immune-microenvironment and potential predictive biomarkers will be helpful in strengthening patients' immunotherapeutic responses [6].

This review focuses on the common GI cancers, specifically pancreatic cancer (PC), colorectal cancer (CRC), and hepatocellular carcinoma (HCC). Four points are discussed here: (1) The influence of pathogen-specific microbes and viral infections on GI cancers in light of chronic inflammation in pathogenesis. (2) The paracrine effect of fibroblasts and how a tumor modulates innate and adaptive immunity. (3) The emerging predictive biomarkers from molecular subtyping that contribute to the tumor immune landscape. (4) The existing and ongoing clinical trials on immunotherapy and their outcomes in GI cancers.

\section{Crosstalk between the Immune System and Microbiomes on Homeostatic Regulation in GI Cancer}

Gut microbiota are comprised of approximately 100 trillion diverse micro-organisms encompassing a varied taxonomy of 2000 distinct species. The microbes contain approximately 5,000,000 genes, which is 100-150 times higher than the genes in the human genome [6]. In healthy humans, the dominant bacterial phyla are Firmicutes (30-50\%), Bacteroidetes (20-40\%), and Actinobacteria (1-10\%) [7]. Gut microbiota play a protective role against disease and a modulatory effect on immune cells [8]. They are also required to stimulate the proper development of gut-associated lymphoid tissues, including the Peyer's patches, crypt, and other structures, while regulating helper T cell-mediated immunity [9]. Commensal bacteria colonize the host at birth and are essential to host development by priming the metabolic, immune, and nervous systems $[10,11]$. The mucosa of both the small and large intestine contain many scattered lymphocytes and lymphatic nodules, each of which are covered by columnar epithelial cells and mucus secreting goblet cells [12]. Homeostasis within the colon is largely maintained by the interaction between intestinal microbes and the immune system, mediated by intestinal epithelial cells. The relationships between microbiome dysbiosis and CRC have been discussed $[13,14]$. The interaction between the liver-pancreas and gut microbiota is indirect. In instances where a certain assault compromises the intestinal barrier, gut-derived bacteria produce lipopolysaccharides (LPS) and other metabolites, which translocate through the portal vein and pancreatic duct, respectively (see Figure 1) [15].

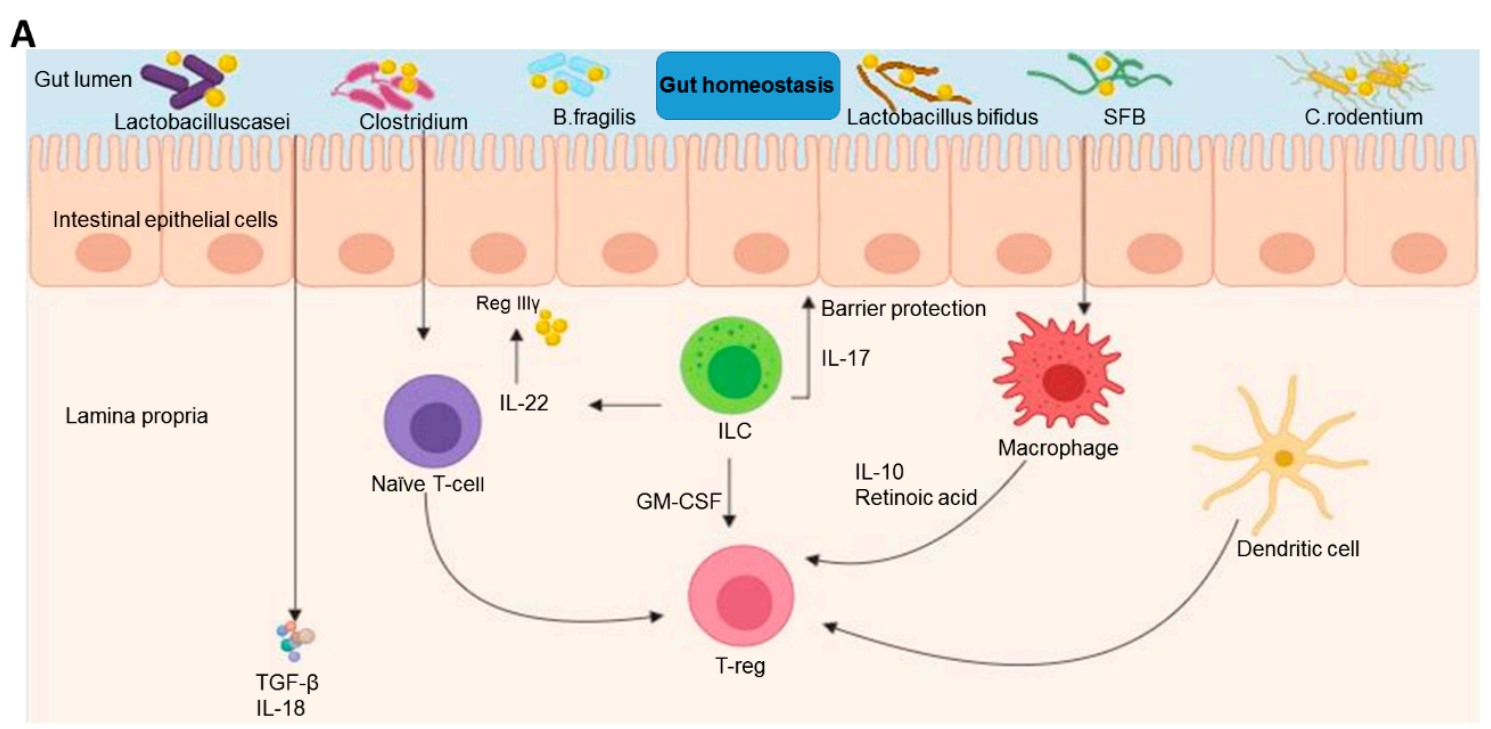

Figure 1. Cont. 
B

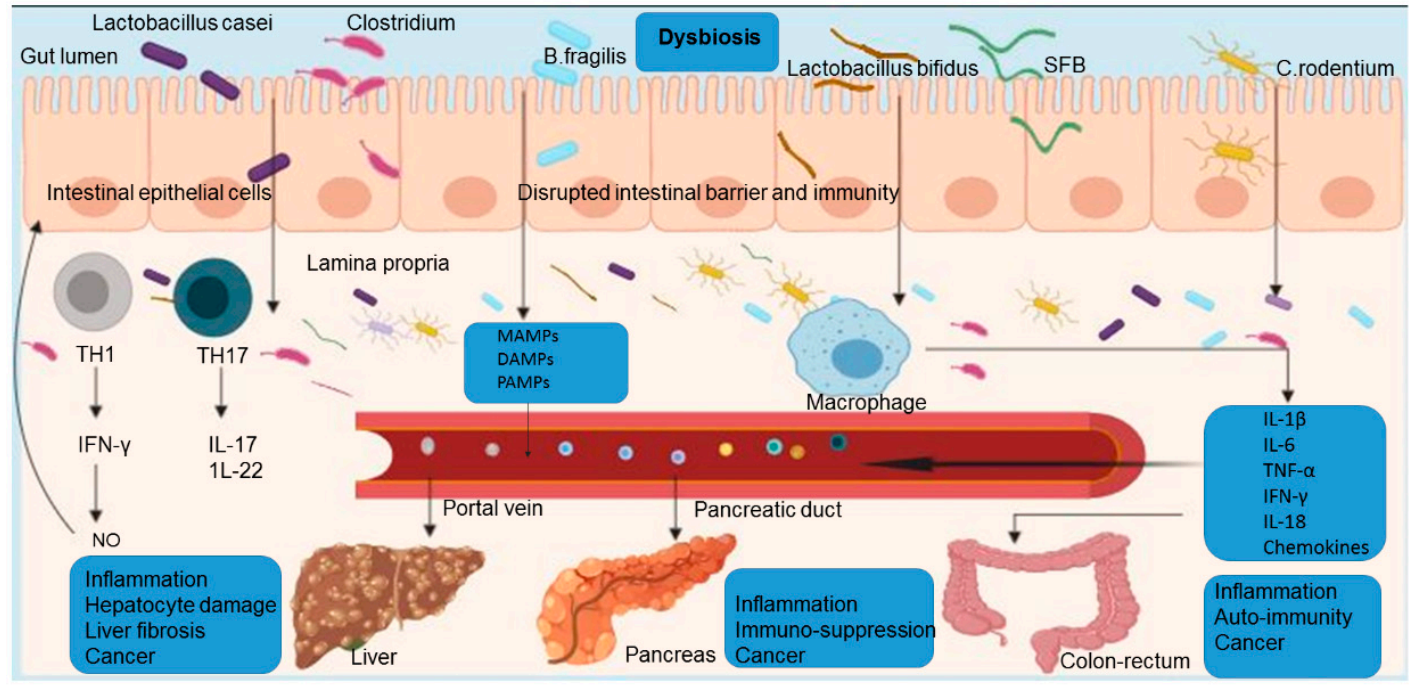

Figure 1. Intestinal homeostasis and dysbiosis of gut microbiomes in gastrointestinal cancer development. (A) Gut homeostasis. The gut homeostasis is maintained by an intricate network of factors such as regenerating islet-derived III-gamma (RegIII $\gamma$ ), interleukin-22 (IL-22) and interleukin-17 (IL-17) secreted by innate lymphoid cells (ILC). These factors regulate the diverse gut microbiome, aid tissue repair, and barrier protection. Inhibition of immune activation by regulatory $\mathrm{T}$ cells (Treg) is aided by interleukin-10 (IL-10), retinoic acid and granulocyte macrophage-colony stimulating factor (GM-CSF) secreted by macrophage and innate lymphoid cells (ILC) respectively. In addition, secreted TGF- $\beta$ and IL-18 preserve the intestinal barrier integrity and also promotes early development of regulatory T cells (Tregs). (B) Dysbiosis. On the other hand, an altered gut barrier due to a dysregulated microbiome disrupts the intestinal barrier resulting to leakage of microorganism associated molecular patterns (MAMPs), pathogens associated molecular patterns (PAMPs) and death associated molecular patterns (DAMPs) into the lamina propria. In addition, $\mathrm{T}$ helper-1 and T helper-17 produce interferon-gamma (IFN- $\gamma$ ), interleukin-17 (IL-17), interleukin -22 (IL-22) and excess nitric oxide, which induce loss of barrier integrity. Macrophages secretes inflammatory factors such as tumor necrosis factor (TNF- $\alpha$ ), interferon- gamma (IFN- $\gamma$ ), interleukin-1 beta (IL-1 $\beta$ ), interleukin -6 (IL-6), interleukin -16 (IL-16), interleukin-17 (IL-17), interleukin-18 (IL-18), and chemokines. These factors translocate via the portal vein and pancreatic duct to the liver and pancreas, respectively, and do so directly unto the colon-rectum, thereby initiating inflammation and cancer.

Though the pancreas was initially presumed to be a sterile organ and not usually exposed to microbiota, Pushalkar et al. [16] reported a 1000-fold increase of the intrapancreatic bacteria of human pancreatic ductal adenocarcinoma (PDAC) compared with normal pancreatic tissue. Similarly, several studies have identified a relationship between microbiota, inflammation, and PC [17]. In addition, Sun et al. [18] found that pancreatic $\beta$-cells express cathelicidin-related antimicrobial peptide under the influence of gut microbiota, thereby exerting an immunoregulatory effect. By contrast, the liver is constantly exposed to microbiota through the liver sinusoid [19]. The liver is a powerful local surveillance and tolerogenic system with a unique blood supply that plays a role in immunological defense and homeostasis.

The liver's first line of defense is conferred by the resident Kuppfer cells (KCs), which enhance hepatic tolerance by stimulating anti-inflammatory cytokines in response to endotoxins while suppressing $\mathrm{T}$ cells through the activation of a toll-like receptor (TLR2) [20]. Exposure of the liver to microbes enhances activation of KC via TLR3, which inhibits immune tolerance and induces T cell response [21]. In addition, liver sinusoid epithelial cells (LSEC) express most of the TLRs and present antigens directly to T cells [22]. Myeloid-derived suppressor cells (MDSCs) are potent activators of suppressive cytokines such as interleukin (IL)-10, IL-17, and transforming growth factor-beta (TGF- $\beta$ ), 
which downregulate the activity of both $\mathrm{CD}^{+}$and $\mathrm{CD} 8^{+} \mathrm{T}$ cells $[23,24]$. Natural killer (NK) cells within the liver respond to cell surface antigens caused by pathogens and stimulate both innate and adaptive responses through their ability to secrete various cytokines (e.g., IL-15, 1L-7, 1L-12, and interferon-gamma (IFN- $\gamma$ ) [25]. These cytokines are counterbalanced by TGF- $\beta$, IL-10, and IL-13 [26]. Hepatic NK cells also exert an immunomodulatory effect via pro-inflammatory and anti-inflammatory cytokines [25]. Therefore, any deregulation of the abovementioned intricate network of immune cells, gut microbiota, and intestinal barrier results in gastrointestinal diseases [27] (see Figure 1).

\section{Influence of Pathogens and Role of Immune Cells in GI Cancer}

\subsection{Influence of Microbiomes on GI Cancer}

The pro-tumorigenic role of gut dysbiosis has been described in different cancers through multiple mechanisms, including metabolic changes, inflammatory cytokines, oncogenic pathways, and adhesion molecules [28]. The bacteria and its metabolites contributes to gastrointestinal cancers. Porphyromonas gingivalis, an important contributor for systemic inflammation, was shown in higher levels in PC patients $[29,30]$. P. gingivalis is an activator of TLR which acts through the immunoglobulin (Ig)-like molecule (B7-H1) receptor and its mediated co-stimulatory signal. This promote the apoptosis of activated T cells [31,32]. Similarly, the proteobacteria (gut microbiota) within the tumor microenvironment have been shown to promote immune suppression through the activation of toll-like receptors in monocytic cells [16]. Hence, proteobacteria ablation results in the immunogenic reprogramming of the tumor microenvironment through enhanced T helper-1 (TH1) differentiation of $\mathrm{CD} 4^{+}$and up-regulation of programmed cell death-1(PD-1) expression [16]. Additionally, the liver tissue is the most common metastatic organ for PC. The recruitment of granulin-secreting inflammatory monocytes to the liver reprograms hepatic stellate cells into myofibroblasts, which supports the growth of metastasizing tumor cells [33]. The accumulation of lipopolysaccharides contributes to the pathogenesis of HCC by activating pro-inflammatory cytokines through toll-like receptor 4 (TLR-4) [34]. TLR activates innate immunity through myeloid differentiation primary-response protein 88-dependent (MyD88) and MyD88-independent pathways [35] (see Figure 2).

Mice deficient in both TLR-4 and MyD88 have shown a significant decrease in the incidence and sizes of chemical-induced liver cancers, suggesting a strong relationship between TLR-4 signaling and hepatocarcinogenesis [36]. Several bacteria such as Fusobacterium nucleatum, Escherichia coli, Bacteroides fragilis, and Enterococcus faecalis are elevated in CRC patients [37]. By contrast, Clostridiales, Faecalibacterium, Blautia obeum, and Bifidobacterium are absent within CRC [38]. Bacteria that colonize the surfaces of the caecum and colon induce inflammation through the T helper- 1 and T helper-17 (Th1/Th17) immune response. This aids the recruitment of tumor-infiltrating myeloid cells and cancer progression $[39,40]$. Studies have shown that STAT3 (signal transducer and activator of transcription 3) activation contributes to inflammatory bowel disease and CRC [41,42]. Bacteria also activates ERK (extracellular signal-regulated kinase) and C-MYC, as demonstrated in an $\mathrm{APC}$ min/+ $/ \mathrm{MyD}^{-{ }^{-/-}}$ mouse models [43]. Dejea et al. reported that $89 \%$ of right-sided and $12 \%$ of left-sided human CRC contain microbial biofilm [44]. Similarly, microbial biofilm from a healthy individual may be a point of transition from a healthy state to a diseased state [45]. Tomkovich et al. [46] demonstrated that microbial biofilm from CRC patients and healthy individuals induces tumor formation when transferred to germ-free mice. Additionally, the microbial biofilm from a CRC patient aggressively promoted tumor growth within one week compared with biofilm-positive homogenates from a healthy individual. Furthermore, the carcinogenic phenotype maintained in a new host is same as the phenotype from the biofilm source. Immune cells such as natural killer T (NKT) cells, myeloid cells, and Th17 were recruited by the biofilm in the germ-free mice. A contrasting role has been reported for Th17, given its involvement in biofilm-induced tumor formation. For example, it is pro-inflammatory through its enhanced secretion of IL-22 and IL-17 [47]. Conversely, an inflammatory-independent role has been reported in F. nucleatum-fed mice [39]. 


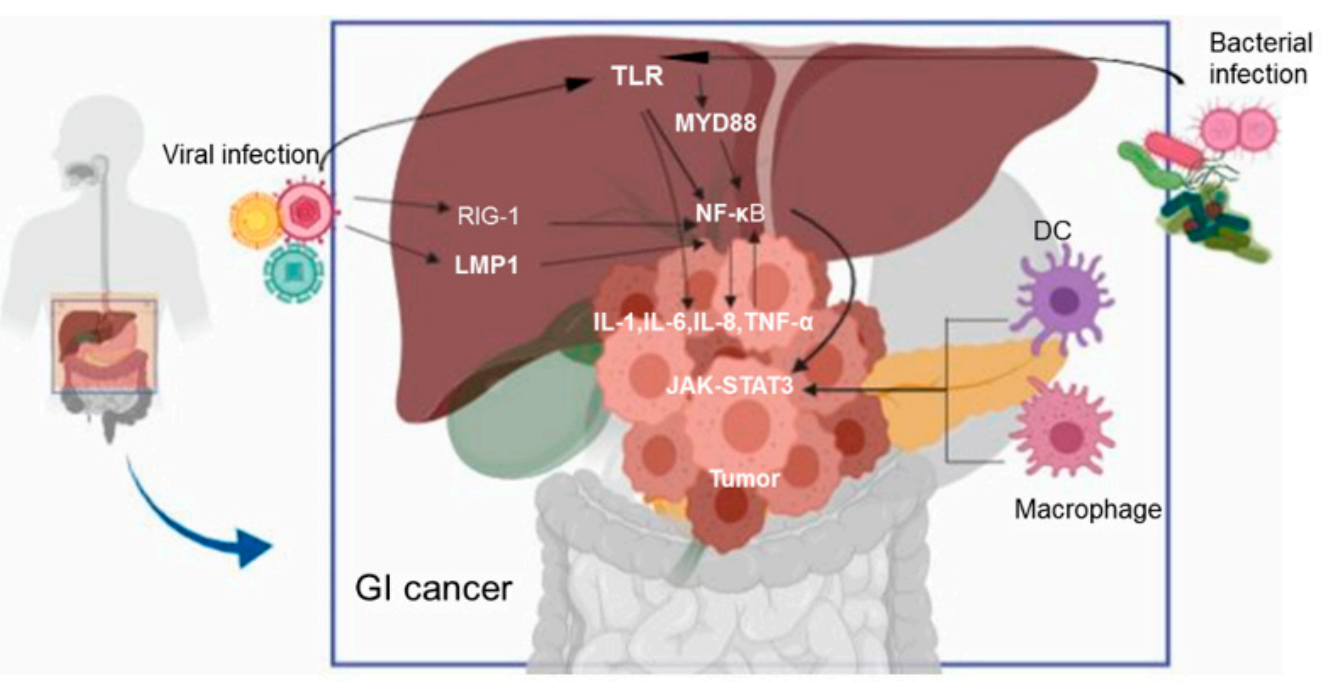

Figure 2. The mechanisms by which pathogens induce gastrointestinal cancer. Nuclear factor-kappa B (NF-kB) is stimulated through virus-induced activation of toll like receptor (TLR), retinoic acid-inducible gene-1 (RIG-1) and Epstein-Barr virus latent membrane protein 1 (LMP1). Bacterial infection also can activate TLR and myeloid differentiation primary response 88 (MYD88) to stimulate NF- $\kappa \mathrm{B}$, which in turn promotes pro-inflammatory cytokines; IL-6, IL-1 $\beta$, IL-8, tumor necrosis factor- $\alpha$ (TNF- $\alpha$ ) and vice versa. The activation of pro-inflammatory cytokines promotes infiltration of dendritic cell, macrophages and other immune cells which activates Janus kinase/signal transducer and activator of transcription 3 (JAK-STAT3). The inflammatory responses and NF- $\mathrm{kB}$ activation promotes cell proliferation and cancer initiation. In addition, the cross-talk between (NF-kB) and JAK-STAT3 stimulate cell growth, angiogenesis and thus accelerate tumorigenesis.

\subsection{Influence of Virali Infection in GI Cancers}

Viral infection agents are risk factors of cancers. The role of human papilloma virus, hepatitis virus (B and C), coxsackie virus, cytomegalovirus (CMV), human immunodeficiency virus, herpes simplex virus, mumps, and varicella-zoster virus have been documented [48]. For example, chronic hepatitis $B$ and $C$ viruses are the leading cause of HCC worldwide [49]. These viruses are also present in the extrahepatic tissue contributing to extrahepatic metastasis in PC [50]. Similarly, transfusion-transmitted virus (TTV), one of the causative agents of hepatitis, has been detected in pancreatic tumor patients [51]. However, the nature of the link between PC and TTV is unknown. Till date, studies regarding the role of viral infection in PC is limited. The presence of viral DNA has been reported in colorectal tumor tissues. For instance, human papillomavirus has been detected in 1,549 samples [52] and BK virus has been detected in 50 clinical specimens [53]. More recently, Mjelle et al. identified micro RNA (miRNAs) from Epstein-Barr virus in CRC tumor samples [54]. Whether viral infections contribute to the development of CRC remains controversial. It is well documented that chronic inflammation is the cause of cancers [55]. Viral infections have been shown to directly initiate cell proliferation and promote inflammation [56]. Residues from death-associated molecular patterns (DAMP) and inflammasomes promote inflammatory cytokines, leading to HCC progression [57]. The inflammatory responses promote lymphocyte infiltration, macrophages, natural killer cells, dendritic cells, and pro-inflammatory cytokines (IL-6 and TNF), which activate STAT3 and NF- $k B$ (nuclear factor-kappa B) [58]. NF- $\kappa B$ stimulates pro-inflammatory cytokines such as IL-6, IL-1 $\beta$, IL-8, TNF- $\alpha$ and chemokines C-X-C motif ligand 1 and 2 (CXCL1 and CXCL2) [59] (see Figure 2). Additionally, pro-inflammatory cytokines exert a stimulatory effect on cyclo-oxygenase (COX)-2, which regulate immunity and maintain gastrointestinal integrity [60]. Hence, the inhibition of STAT3 and NF- $\kappa B$ abolish inflammation in animal models of HCC [61], PC [62], and CRC [63]. Conversely, the inhibition of NF- $\mathrm{kB}$ enhances HCC, thereby damaging hepatocytes in animal models of hepatitis B-virus (HBV)-driven HCC [64]. Therefore, NF- $\mathrm{kB}$ poses a challenge due to its opposing role in HCC. Furthermore, the persistent 
activation of the immune system due to viral infection results in organ damage due to a weakened and overpowered immune system [65], leading to T and NK cell exhaustion [66]. It has been shown that a memory-like virus-specific $\mathrm{T}$ cell is elevated without cessation despite the withdrawal of chronic antigen stimulation during viral infection [67]. Exhausted T cells express multiple inhibitory receptors such PD-1, lymphocyte activation gene-3 (LAG-3), T cell immunoreceptor with Ig ITIM domains (TIGIT) [68]. Similarly, exhausted NK cells also express NKG2A as a checkpoint molecule during viral infection. A recent study identified thymocyte selection-associated high mobility group box protein (TOX) as the main regulatory protein in exhausted T cells [69]. The similarities between virus-induced $\mathrm{T}$ cell exhaustion and dysfunctional $\mathrm{T}$ cells in cancer have been a major debate. However, limited knowledge exists on the similarities between dysfunctional $\mathrm{T}$ cells in cancer and exhausted $\mathrm{T}$ cells in viral infection. The persistent activation of $\mathrm{CD} 8^{+} \mathrm{T}$ cells results in loss of their effector function. This leads to dysfunctional $\mathrm{T}$ cells with molecular profiles that distinguishes them from exhausted cells in chronic viral infection [70]. By contrast, Miller et al. [71] identified a shared epigenetic program of exhaustion that is independent of the disease-specific milieu by comparing exhausted $\mathrm{CD} 8^{+} \mathrm{T}$ cells from mice infected with lymphocytic choriomeningitis virus and $\mathrm{CD} 8^{+} \mathrm{T}$ cells isolated from ovalbumin-expressing B16F10 (B16-OVA) mouse melanoma tumors. Studies from transcriptome analysis have shown high similarities between T cell dysfunction in HCC and exhausted T cell from chronic HBV infection. However, viral induced exhausted T cells and non-viral dysfunctional $\mathrm{T}$ cells possesses specific genes and signaling pathways [72]. Exhausted $\mathrm{CD} 8^{+} \mathrm{T}$ cells still have effector functions in both chronic viral infection-induced tumors and cancers without viral infection [71,73]. The effector function is regulated by a balance between the two major subpopulations of the exhausted T cells (progenitor exhausted and terminal exhausted cells) (see Figure 3).

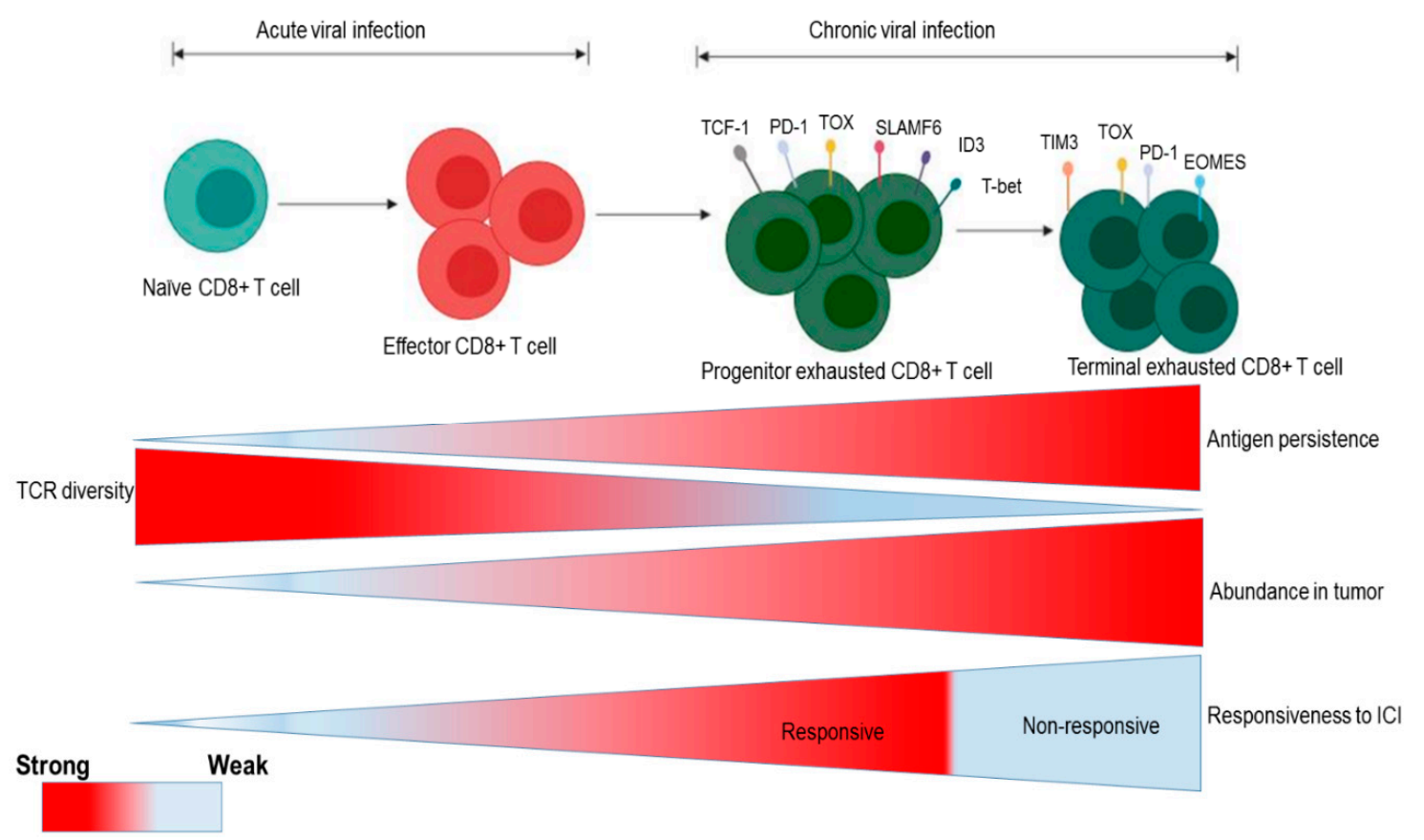

Figure 3. Viral infection promotes $\mathrm{T}$ cell exhaustion. The chronicity of viral infection determines the fate of $\mathrm{CD}^{+} \mathrm{T}$ cell. During acute viral infection, naïve $\mathrm{CD} 8^{+} \mathrm{T}$ cells differentiate into effector $\mathrm{CD} 8^{+} \mathrm{T}$ cells. These subset of effector $\mathrm{CD} 8^{+} \mathrm{T}$ cells possess an effective cytotoxic activity through diverse $\mathrm{T}$ cell receptor (TCR). However, chronic viral infection promotes antigen persistence, causing expression of exhaustion markers on $\mathrm{T}$ cells and a phenotype switch to an exhausted state. Exhausted T cells have two subpopulations; progenitor exhausted and terminally exhausted $\mathrm{T}$ cells. The progenitor exhausted $\mathrm{T}$ cells are responsive to immune checkpoint inhibitor (ICI), whereas terminally exhausted T cells are more abundant within the tumor and are non-responsive to immune checkpoint inhibitor (ICI). 
The terminally exhausted $\mathrm{T}$ cells with a shorter life span have $\mathrm{CD} 8^{+} \mathrm{T}$ cell cytotoxic effector function [74]. By contrast, progenitor-exhausted cells have a longer life span but a poor cytotoxic effect [71].

\subsection{Paracrine Effect of Fibroblasts on GI Cancer}

Fibroblasts are spindle-shaped cells found within loose connective tissue [75]. They consist of protein fibers composed of collagen (collagenous fibers) scattered loosely within the confines of the extracellular matrix. Fibroblasts are activated not only in wound healing but also in cancer, and are referred to as cancer-associated fibroblasts (CAFs). CAFs are a major subset in the tumor microenvironment that provide cues to cancer cells in the form of secretions, aiding their growth in a paracrine manner [76]. Though the specific origin of CAFs remains controversial, studies have proposed that they consist of a diverse subset that is differentiated from a specific origin such as conventional fibroblasts in the early stages of a tumor [75], recruitment from bone marrow-derived mesenchymal stem cells [77], or non-fibroblast lineage (epithelial cell, blood vessels or serosa, and stem cell origin) [78]. More recently, a distinct population of CAFs was found in breast cancer and NSCLC. These populations express complement 5a G-protein coupled receptor-77 (GPR77) and $\mathrm{CD} 10$ with the ability to promotes stemness and chemoresistance through the NF- $\mathrm{kB}$ activation and cytokine secretion (IL-6 and IL-8) [79]. Furthermore, CAF have specific markers that are shared with other cell types. For instance, a fibroblast marker known as alpha smooth muscle ( $\alpha$-SMA) is also expressed by the smooth muscle cell of GIT. Ozdemir et al. [80] found that depleted $\alpha-\mathrm{SMA}^{+}$cells led to tumor progression in a PDAC mouse model. Conversely, the high expression of fibroblast activation protein (FAP) has been found to correlate with poor prognosis in both CRC and PDAC. Therefore, the depletion of FAP leads to impaired tumors in both types of cancer [81-83]. It is known that sonic hedgehog signaling pathways contribute to the development of tumors. However, the use of hedgehog inhibitors in pre-clinical and clinical studies has failed to alleviate tumor progression in both PDAC and CRC $[84,85]$. FAP ${ }^{+} \mathrm{CAFs}$ modulate the tumor microenvironment through secretions such as C-C motif chemokine ligand 1, 2 and 5 (CCL1, CCL2, CCL5) and CXCL12 in HCC [86]. In addition, CAFs recruits monocytic MDSCs (M-MDSCs), regulatory T cells (Treg CD4 ${ }^{+} \mathrm{CD} 25^{+}$cells) and initiates macrophage polarization $[87,88]$. However, evidence has suggested that MDSCs recruited by CAF exert a neutralizing effect within the tumor microenvironment [89]. Inflammatory cytokines such as IL-6, IL-1, and TGF- $\beta$ secreted by CAF inhibit both IFN $\gamma$ secretion in PC and the tumoral infiltration of $\mathrm{CD}^{+} \mathrm{T}$ cells in colon cancer $[90,91]$. Recently, a study showed that both hepatocyte growth factor (HGF) and IL-6 secreted by CAF promote stemness in CD24 ${ }^{+}$HCC through STAT3 activation [92]. Colony stimulating factors (CSF) have been shown to modulate the crosstalk between CAFs and cancer cells via CXCL1 [89]. Clinical studies reported a minimal effect of the CSF-1 inhibitor on the disruption of such crosstalk in gastrointestinal tumors [93]. CAFs and CD90 ${ }^{+}$colonic (myo)fibroblasts express PD-1, which suppresses Th1 helper T cells in ulcerative-induced colitis patients [94] as well as CD8 ${ }^{+} \mathrm{T}$ cells [95]. In addition, CAF also exerts a modulatory effect on neutrophils by increasing PD-L1, IL-8, TNF- $\alpha$, and CCL2 expression thereby inhibiting T cell response [96].

\subsection{Drivers of Innate Immunity and GI Cancer}

\subsubsection{NK Cells}

NK cells are a component of innate immunity and the first line of defense against foreign agents within the body. They kill target cells without prior notice at first sight and recruit the adaptive immune components to reinforce the immune response through cytokine secretion [97,98]. NK cells can be distinguished by the expression of CD16 and CD56, constituting CD56 bright/CD16 (tissue NK cells) and CD56 dim/CD16 (blood) subsets. The cytotoxic effect of NK cells are primarily attributed to the CD56 dim/CD16 ${ }^{+}$subset, which constitutes approximately $90 \%$ of NK cells [99]. CD 16 plays an important role in the activation of NK cells by binding to the Fragment crystallizable ( $\mathrm{Fc}$ ) portion of 
immunoglobulins and causing the release of cytokine, thereby recruiting adaptive immunity through antibody-dependent cell-mediated cytotoxicity [100]. The number of NK cells has been reported to outnumber CD8 ${ }^{+}$T cells in liver tumors [101]. Despite this, NK cell function is diminished in HCC. Several explanations for this phenomenon have been proposed, including NK cell exhaustion or dysfunction [102], low levels of liver-resident NK cells causing hypo functionality, non-resident cells maintaining much higher expression [103] and the upregulation TFG- $\beta$ and IL-10 through the activation of STAT3 [104]. Similarly, a reduced level and activity of NK cells has been reported in patients with PC and CRC compared with healthy controls $[105,106]$. Another study showed that the activity of NK cell-induced interferon- $\gamma$ is impaired in post-operative CRC patients, resulting in the recurrence and formation of early micro metastases [98]. Post-operative impaired NK cell interferon- $\gamma$ secretion has been reported as a T cell suppressor in a study using OVA-specific T cells [107]. The impaired activity of NK cell and reduced level of NKG2D was reported in advanced PC. By contrast, increased NKG2D expression was reported in resected PC [108]. However, a recent study found no correlation between NKG2D and interferon- $\gamma$ secreting NK cells [109].

\subsubsection{Dendritic Cells}

Dendritic cells (DCs) are antigen-presenting cells that play a crucial role by inducing anti-tumor immune responses. The priming of the effector $\mathrm{CD} 8^{+} \mathrm{T}$ cell response by $\mathrm{DCs}$ has been well documented in several cancers [110]. Furthermore, a recent study demonstrated that IL-33 enhances and promotes the cytotoxic activities of a DC-induced $\mathrm{CD}^{+} \mathrm{T}$ cell newly identified subset 9 (Tc9). These activities inhibit the differentiation of exhaustive $\mathrm{CD} 8^{+} \mathrm{T}$ cells by decreasing expression of both 2B4 (CD244) and PD-1 while increasing IL-2 and CD127 (IL-7R $\alpha$ receptor) expression on CD8 ${ }^{+} \mathrm{T}$ cells in an OT-I melanoma mouse model [111]. Despite the reported anti-tumor effect of dendritic cells, several studies have also shown their immunosuppressive role in human tumors including GI cancers. In HCC, Fc $\gamma$ RII low/- activated B cells are generated by semi-mature dendritic cells through CD95L-dependent pathway. The activated Fc $\gamma$ RII low/- B cells from the HCC tumor subsequently suppress autologous tumor-specific cytotoxic T cell immunity through IL-10 [112]. Similarly, Yuan et al. [113] demonstrated an increased number of immature dendritic cells and a decreased number of mature dendritic cells in CRC tumor tissues. The decreased number of mature dendritic cells is associated with tumor escape from the immune system [114]. Furthermore, trefoil factor 2 was reported as the main chemoattractant for immature dendritic cells with no impact on its phenotypic maturation in pancreatic cancer [115]. Interestingly, a distinct subset of dendritic cells, $\mathrm{CD} 103^{-} \mathrm{CD} 11 \mathrm{~b}^{+} \mathrm{DC}$, drives $\mathrm{CD} 4^{+} \mathrm{T}$ cell tolerance and also express TGF- $\beta$, IL-23 and IL-10 ${ }^{+}$IL-17 $7^{+}$FOXP3 ${ }^{\text {neg }}$ Tregs (Tr1 cells) [116]. The ablation of the $\mathrm{CD} 103^{-} \mathrm{CD} 11 \mathrm{~b}^{+}$DC subset mitigates the CD4 ${ }^{+} \mathrm{T}$ cell expression of IL-17 and retinoic acid receptor-related orphan receptor gamma-t (ROR $\gamma \mathrm{t}$ ) in PDA-bearing CD11c.DTR bone marrow chimeric mice [116]. Tr1 cells eliminate $\mathrm{CD} 8^{+} \mathrm{T}$ cells through perforin-granzyme $\mathrm{B}$ and also suppress innate immunity through IL-10 in myeloid cells $[117,118]$. The use of DCs in both HCC and CRCs as a therapeutic window is an ongoing area of research [119].

\subsubsection{Macrophages}

Macrophages are cells of the mononuclear phagocyte system. There are two types of macrophage; namely M1 (activated) and M2 (alternatively activated), which expresses CD163. M1 is pro-inflammatory and anti-tumor, whereas M2 is anti-inflammatory, pro-tumorigenic, promotes angiogenesis and repairs damaged tissue [120]. Tumor associated macrophage (TAMs) are immune-related stromal cells which provide support for cancer cells [121] and have the ability to modulate chemoresistance by activating autophagy [122]. Studies have reported that recurrence and cancer-related death occur in patients with high TAM infiltration within the tumor stroma [123]. Consistently, evidence from animal studies has also shown a detrimental effect of high infiltrated TAM2 rather than the total TAM population [124]. The prevalence of high tumor-infiltrating TAM2 correlates with larger tumor size and poor prognosis in solid tumors, including PC [125] and 
HCC [126]. Studies have shown that TAM1 is localized to the perivascular niche, in contrast to the TAM2 which is found in hypoxic areas [127]. The $\mathrm{C}-\mathrm{C}$ chemokine ligand type 2 and receptor (CCL2/CCR2) pathway is required for the mobilization of monocytes from the bone marrow into the tumor microenvironment [128]. Bartneck and colleagues [129] reported an accumulation of a distinct subset of macrophage, CCR2 ${ }^{+}$TAM at the stroma/tumor interface within a highly vascularized region in resected HCC. This subset of macrophage expresses an inflammatory marker S100a9 rather than CD163. Hence, the depletion of CCL2 results in reduced TAM, pathogenic angiogenesis and tumor progression. Additionally, IL-34, IL-35, IL-10, IL-4, TGF- $\beta$, and CSF-1 promote the differentiation, survival, and recruitment of macrophages into the tumor microenvironment [130-133]. The abrogation of colony-stimulating factor 1 and its receptor (CSF-1/CSF-1R) depletes CD206 $6^{\text {hi }}$ TAMs and also reprograms residual TAMs to promote antigen presentation and T cells in an experimental model of PDAC [134]. As opposed to the beneficial effect of the CSF blockade, they also upregulate immune checkpoint molecules; PD-1 and cytotoxic T-lymphocyte-associated protein4 (CTLA-4). Another study also showed that TAMs can be derived from tumor-infiltrating monocytes, which express an elevated level of programmed cell death-ligand 1 (PD-L1), suppressing cytotoxic T cell responses [135]. Hence, the combination of a CSF inhibitor and an immune checkpoint antagonist inhibits tumor progression [134]. Consistently, the depletion of a specific extratumoral macrophage Ly6C $\mathrm{C}^{\text {low }} \mathrm{F} 4 / 80^{+}$ enhances $\mathrm{CD}^{+} \mathrm{T}$ cell tumor infiltration in response to CD40 agonist immunotherapy [136]. A study identified Kupffer cells as a TAM population that promotes tumor progression in HCC [137]. However, it is difficult to determine the functional role of $\mathrm{KC}$ due to a lack of animal experimental models that can selectively inhibit KC without resulting in liver toxicity to confirm the observation [138]. There is a contrasting evidence regarding the exact role of TAM in CRC, as it has been shown to exert both beneficial and detrimental effects on this type of cancer [139]. Khorana et al. [140] reported that vascular endothelial growth factor (VEGF)-expressing TAM increases median survival in patients with colon carcinoma, and a decreased number of macrophages is associated with more advanced stages among CRC patients. By contrast, pancreatic macrophages express VEGF-A, VEGF-C, and basic fibroblast growth factor (FGF), promoting angiogenesis and tumor invasiveness [141]. Of particular clinical relevance was a finding that macrophage orchestrates resistance to anti-VEGF therapy and macrophage depletion could improve VEGF blockade [142].

\subsubsection{Myeloid-Derived Suppressor Cells}

Myeloid derived suppressor cells (MDSCs) are immature myeloid-derived cells. These cells suppress immune response through an array of secretory factors such as arginase, nitrites, reactive oxygen species (ROS), immunosuppressive cytokines and the expansion of immunosuppressive cells (Tregs) [143,144] (see Figure 4). Impaired myelopoiesis results in defective differentiated progenitor cells in cancer [145]. This alters their phenotype, similar to TAM and tumor-associated neutrophil, and these are referred to as M-MDSCs and polymorphonuclic or granulocytic (G-MDSC/PMN-MDSC) [146,147]. Murine MDSCs are characterized by the co-expression of CD11b, an $\alpha-\mathrm{M}$ integrin, and the myeloid differentiation antigen Gr1 [148], whereas human M-MDSCs are characterized by CD11b ${ }^{+} \mathrm{CD} 14^{+} \mathrm{HLA}-\mathrm{DR}{ }^{\mathrm{low}} /{ }^{-} \mathrm{CD} 15^{-}$and PMN-MDSCs as CD14-CD11b ${ }^{+} \mathrm{CD} 15^{+}$ $\left(\right.$ or $\mathrm{CD} 66 \mathrm{~b}^{+}$) cells [149]. CD38, a transmembrane receptor-ectoenzyme, is highly expressed in both the M-MDSCs and G-MDSC/PMN-MDSC of CRC patients [150]. Studies have shown that the high infiltration of MDSC correlates with a poor prognosis in most cancers [151,152]. Consistently, reports from a KrasLSL. ${ }^{\mathrm{G} 12 \mathrm{D} /+}$; $\mathrm{p} 53^{\mathrm{R} 172 \mathrm{H} /+}$; Pdx ${ }^{\mathrm{Cretg} /+}$ (KPC) model of metastatic PC showed that MDSCs positively correlate with cancer cell metastases and suppresses $\mathrm{T}$ cell proliferation through GM-CSF [143]. Another study showed that a population of CD14 ${ }^{+} \mathrm{HLA}^{-} \mathrm{DR}^{\text {low }} \mathrm{M}-\mathrm{MDSC}$ catabolizes L-arginine, which inhibits T cell-induced IFN- $\gamma$ and NKp30-induced cytotoxicity in HCC [153,154]. However, the administration of exogenous L-arginine to the co-culture medium reversed IFN- $\gamma$ secretion. Similarly, the accumulation of $\mathrm{CD} 11 \mathrm{~b}^{+} \mathrm{Gr} 1^{+}$MDSCs-induced IL-10 has also been shown to 
promote colitis-induced CRC through epigenetic upregulation of DNA methyl transferase (DNMT3b and DNMT1), as well as a decreased expression of interferon regulatory factor 8 [155].

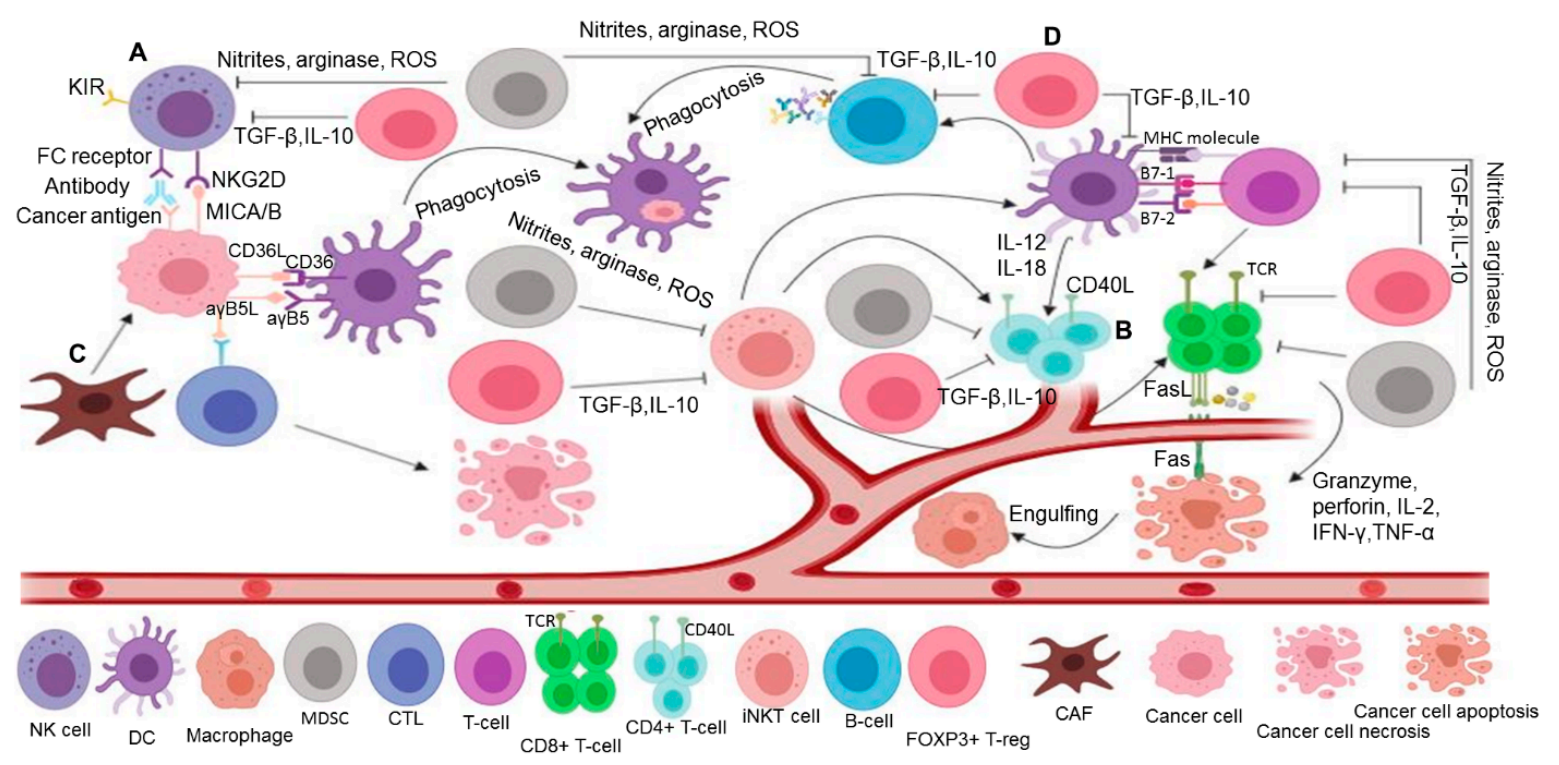

Figure 4. The role of immune cells in cancer development. (A) NK cells are the first line of innate immunity, activated by NKG2D and CD16 (Fc receptor) to promotes cancer cell killing through an antibody dependent cell-mediated cytotoxicity (ADCC effect). (B) The activation of $\mathrm{CD} 4^{+} \mathrm{T}$ cells, $\mathrm{CD} 8^{+}$ $\mathrm{T}$ cells and B cells promotes phagocytosis of cancer cells by dendritic cells and macrophages through Fas/FasL, granzymes, perforins, interleukin-2 (IL-2), tumor necrosis factor (TNF- $\alpha$ ), and interferon $-\gamma$ $($ IFN- $\gamma$ ). (C) Cancer associated fibroblast (CAF) provides support for cancer cells to promotes immune escape. (D) By contrast, these anti-tumor function is counteracted by the presence of fork head box P3 $\left(\mathrm{FOXP}^{+}\right) \mathrm{T}$ regs (regulatory T cell) and myeloid-derived suppressor cells (MDSC) through production of TGF- $\beta$, IL-10, arginase, nitrites and ROS.

\subsection{Drivers of Adaptive Immunity and GI Cancer}

\subsubsection{T Lymphocytes}

The subset of total $\mathrm{CD}^{+} \mathrm{T}$ cells includes cytotoxic $\mathrm{CD}^{+} \mathrm{T}$ cells, $\mathrm{CD} 4^{+}$helper $\mathrm{T}$ cells and $\mathrm{CD} 4^{+} \mathrm{CD} 25^{+}$Tregs. Cytotoxic $\mathrm{CD} 8^{+} \mathrm{T}$ cells physically attack foreign invaders through perforins, granzymes, and a FasL/receptor [156] (see Figure 4). By contrast, B lymphocytes kill at a distance through humoral immunity (the secretion of antibodies). Cytotoxic T cells secrete IFN- $\gamma$ and TNF- $\alpha$, and combat invading molecules through major histocompatibity complex (MHC) class I [157]. Helper $\mathrm{T}$ lymphocytes aid B lymphocytes and killer T lymphocytes through the secretion of chemical regulators called lymphokines (i.e., IL-22). Fork head box P3 (FOXP3) ${ }^{+}$Tregs secrete IL-10 and TGF- $\beta$, which inhibit both B lymphocytes and T lymphocytes. CD8 ${ }^{+} \mathrm{T}$ cells are the main constituent of tumor-infiltrating lymphocyte (TILs) that perform the effector function. Studies have shown that the distribution and density of TILs determine the functional states within the tumor microenvironment (i.e., anti-tumorigenic or pro-tumorigenic) [158]. The distribution of TILs varies significantly among different cancer types. For instance, TILs are confined to the peritumoral tissue in PC patients [159] and both peritumoral and intra-tumoral in CRC patients [160]. A higher infiltration correlates with longer survival in human cancer [161,162]. The anti-tumor effector function requires the infiltration of $\mathrm{CD}^{+} \mathrm{T}$ cells within the tumor. Hence, a lower number or absence of $\mathrm{CD} 8^{+} \mathrm{T}$ cells within tumors have been implicated as major obstacles for immunotherapies in solid tumors, especially in PC [163]. Mounting evidence over the years has shown the potential mechanism responsible for the reduced TIL infiltration. Zhang et al. [164] reported that CD11b ${ }^{\text {hi }} F 4 / 80^{\text {low }}$ tumor-associated myeloid cells secrete the S100a9 protein through CCL5, which inhibits the accumulation of CD8 ${ }^{+}$ 
$\mathrm{T}$ cells. The blockage of CCL5-enhanced $\mathrm{CD} 8^{+} \mathrm{T}$ cell mobilization and reduced secretion of the S100a9 protein in a CRC mouse model. In addition, the downregulation of type I interferon receptor (IFNAR1), which maintains the pool of CTL (cytotoxic T cell), promotes immune privileged niche [165]. The stabilization of IFNAR1 improves CTL and enhance the efficacy of chimeric antigen receptor T and PD-1 inhibition. Furthermore, the lack of neoantigens expressed in cancer cells may also result in poor TIL infiltration [166]. In addition, exosome derived 14-3-3 (14-3-3 protein zeta) results in an impaired anti-tumor effect of TILs, thereby contributing to T cell exhaustion [167]. The depletion of $\mathrm{CD}^{+} \mathrm{T}$ cells has been reported to promote tumor development in fumarylacetoacetate-induced hepatitis in fumarylacetoacetate hydrolase-deficient mice [168]. However, a study showed that the pro-tumorigenic role of $\mathrm{CD} 8^{+} \mathrm{T}$ cells is due to lymphotoxin a and $\mathrm{b}$, which promote chronic inflammation-induced tissue damage and HCC $[169,170]$. As opposed to their pro-tumorigenic role, lymphotoxins exert an anti-tumor response in numerous human cancers [171]. However, the mechanism underlying the switch from an anti-tumoral to a pro-tumorigenic effect is unknown. In addition, exosome-derived 14-3-3 $\zeta$ (14-3-3 protein zeta) results in an impaired anti-tumor effect of TILs, thereby contributing to T cell exhaustion [167]. Studies have shown that tumor-specific CD4 ${ }^{+} \mathrm{T}$ cells have complex roles beyond supporting $\mathrm{CD} 8^{+} \mathrm{T}$ cells. $\mathrm{CD} 4^{+} \mathrm{T}$ cells are predominantly subtyped into Th1- and Th2-based on cytokine secretion. Th2 exerts an anti-tumor function, and an imbalance between Th1 and Th2 contributes to tumor progression. Studies have demonstrated an association between Th2 dominance and cancer [172], whereas Th1 confers a good prognosis in cancer [173]. Interestingly, $\mathrm{CD} 4{ }^{+} \mathrm{T}$ cells have the ability to convert and switch to $\mathrm{CD} 4{ }^{+} \mathrm{CD} 25^{+}$Treg [174]. Studies have shown that thymus-derived Tregs or peripheral-derived Tregs may mediate the conversion of $\mathrm{CD} 4^{+} \mathrm{T}$ cells $[174,175]$. Tregs promote immune suppression by secreting TGF- $\beta$ and IL-10 [176]. Contrarily, Tregs are associated with a good prognosis in CRC [177]. Th17 is another type of helper T cell induced by TGF $\beta$ - and IL-10. Th17 secretes IL-17, a pro-inflammatory cytokine which mediates tumorigenic and angiogenic effects. The frequency of IL-17 positively correlates with tumor recurrence in HCC, CRC, and pancreatic intraepithelial neoplastic cells [178-180]. Neutrophil recruitment induced by IL-17 aggravates nonalcoholic steatohepatitis via fatty acid release, resulting in HCC [181]. By contrast, Amicarella et al. [182] reported that IL-17 promotes the recruitment of cytotoxic CD8 ${ }^{+} \mathrm{T}$ cells and beneficial neutrophils via CCL5-CCL20 and IL-8, respectively. The cytokine-induced killer (CIK) cells are subset of $\mathrm{CD} 8^{+} \mathrm{T}$ cells derived from human peripheral blood lymphocytes. CIKs are expanded in vitro using IL-2, IFN- $\gamma$, and anti-CD3 antibodies. Other reported sources of CIK cells include the bone marrow and umbilical cord $[183,184]$. CIK cells are classified into two subsets, $\mathrm{CD}^{-} \mathrm{CD}^{-} 6^{+}$and $\mathrm{CD}^{+} \mathrm{CD}^{-} 6^{-}$, due to their expression of CD16 and CD56 [185] and $\mathrm{CD}^{+} \mathrm{CD}^{2} 6^{+}$, which perform the effector function. CIK cells attack cancer cells via the Fas ligand [186] and NK-activating receptors such as NKG2D, NKp30, and NKp46 [187,188]. CIK cells serve as a form of adoptive T cell therapy (ACT), whereby a patient's own peripheral blood mononuclear cell is used to expand anti-tumor CIK cells that are subsequently reinjected back into patients. Donor CIK cells are also used as alternatives in cases where a patient's own CIK cells are insufficient.

\subsubsection{B Lymphocytes}

B lymphocytes are critical for humoral immunity by killing invaders at a distance. B lymphocyte consists of three subsets: B1 lineage, MZ (marginal zone) lineage, and FO (follicular) lineage. B lymphocytes have the ability to present antigenic peptides to $\mathrm{CD}^{+}$and $\mathrm{CD} 8^{+} \mathrm{T}$ cells [189]. Several studies have shown that B lymphocytes express cytokines and co-stimulatory molecules primarily for T cell activation, such as IFN- $\gamma$, BCL-6, CD 40L, and CD28 [190-192]. However, they are not as potent as DCs. In addition, they express TLRs, which are activated by pathogen-associated molecular patterns [192]. Controversy exists regarding the exact role of B lymphocytes in solid tumors. They have been reported to promote tumor growth by inhibiting $\mathrm{CD} 4^{+} \mathrm{T}$ cell priming and the cytotoxic effect of $\mathrm{CD}^{+} \mathrm{T}$ cells in B cell-deficient mice [193]. Similarly, hepatic B lymphocytes have been found to downregulate surface co-stimulatory CD80 expression through interactions with 
intrahepatic MDSCs in a colorectal liver metastasis model, leading to impaired T cell activation [194]. This can be reversed in the absence of MDSC through STAT3 signaling, which is the key factor regulating MDSCs. B cells have also been implicated in promoting an immunosuppressive milieu through secretion of IL-10 in HCC [195]. Another study showed that B lymphocytes can switch and convert to B-reg phenotypes [196]. A higher B lymphocyte-activating factor correlates with disease progression in HBV-HCC, indicating poorer median survival compared with non-HBV-HCC and non-HCC controls [197]. In PDAC, a subset of B lymphocyte $\mathrm{CD}^{+}$secretes IL-35 which promotes tumor growth [198]. Gunderson et al. [199] found that B cells promoted macrophage polarization to an immunosuppressive phenotype and further confirmed the pro-tumorigenic role of $B$ cells by transplanting PDAC cells into B-cell-deficient mice. Conversely, the amount of B lymphocytes present in HCC has been reported to correlate with $\mathrm{T}$ cell activation markers, indicative of a close interaction between both T- and B-cells and a better prognosis [200]. Furthermore, B cell-depleted mice indicates that B cells might be critically involved in decreasing tumor growth in established HCC, while the prevention of initial tumor formation is a role played by T cells [201]. Similarly, the infiltration of $\mathrm{CD} 20^{+} \mathrm{B}$ cells in metastatic $\mathrm{CRC}$ has been reported to improve survival rates [202].

\subsubsection{NKT Cells}

Natural killer T cells (NKTs) are subset of T cells that possesses an antigen-specific $\mathrm{T}$ cell receptor (TCR) that recognizes self and foreign antigens, specifically lipid antigens i.e., $\alpha$-galactosyl ceramide $\left(\alpha\right.$-GalCer) that are undetected by $\mathrm{CD}^{+}$and $\mathrm{CD} 4^{+} \mathrm{T}$ lymphocytes. NKTs can be iNKT (Type I NKT cells), with an invariant TCR, or Type II NKTs (variable or diverse TCR). Invariant NKTs have been reported to produce anti-tumor factors such as IFN- $\gamma$ and activate both CTL and NK cells [203], whereas variable NKTs inhibit anti-tumor immunity. Contrasting results regarding the role of iNKT cells have been reported in gastrointestinal tumors, especially CRC. For instance, an abundance of NKT cells in HCC has been reported [204,205]. The profibrotic role has also been reported in the non-alcoholic steatohepatitis (NASH) model of HCC [205]. By contrast, a study showed that a strain of gut microbiome (Clostridium species) uses bile acids as a messenger to regulate CXCL16 levels in LSECs, thereby increasing CXCR6 ${ }^{+}$hepatic NKTs. The accumulated NKTs inhibit tumor growth in primary and metastatic liver tumors [206]. Similarly, the absence of NKTs is associated with increased pancreatic tumor development and progression in LSL-Kras ${ }^{\mathrm{G} 12 \mathrm{D} /+}$ mice. The pharmacological inhibition of arachidonate 5-lipoxygenase (5-LOX) and microsomal prostaglandin E synthase-1 (mPGES-1) led to reversal of the NKT population, enhanced $\mathrm{CD} 8^{+} \mathrm{T}$ cells, and tumor suppression [207]. Moreover, higher Valpha24 ${ }^{+}$NKT cell infiltration in colorectal carcinomas has been reported as an independent factor for favorable prognosis [208]. By contrast, evidence regarding the role of NKTs in intestinal inflammation in both human and animal models of ulcerative colitis suggests that NKTs may favor tumor development in intestinal tissue. Wang et al. [209] investigated the iNKT-mediated regulation of tumor immunity in an orthotopic spontaneous model of the early stages of intestinal cancer in Apc min/+ mouse model of CRC deficient of all NKT and/iNKT cell. The study found a reduction in intestinal polyps, an increased proportion of FOXP3 Tregs, and a reduced expression of genes associated with TH1 in the absence of iNKT. In the presence of iNKTs, an enhanced proportion of M2 macrophages and MDSCs was found in the presence of iNKT. Consistently, Heller et al. [210] that reported the pro-inflammatory role of iNKTs in a mouse model of intestinal disease.

\subsubsection{Regulatory T Cells}

Tregs are characterized by their ability to activate the FOXP3 gene. Tregs release cytokines such as IL-10, CTLA-4, and TGF- $\beta$, and exerts an inhibitory effect on both B- and T-lymphocytes (see Figure 4). It has been shown that Tregs may have an influence on macrophages (M1/M2) and neutrophils (N1/N2) phenotype [211]. Tregs also promote the destruction of their target cells by releasing granzymes and perforins. The high prevalence of Treg $\mathrm{CD} 4{ }^{+} \mathrm{CD} 25^{+} \mathrm{FOXP} 3$ correlates with the poor prognosis and recurrence of solid tumors, including HCC and PC [212,213]. However, the role of Tregs in CRC 
remains controversial. As opposed to the immunosuppressive role of Tregs, numerous studies have shown that the high intra-tumoral frequency of Tregs correlates with good prognosis in patients with CRC [214-216]. By contrast, Tregs within the same type of tumor suppress $\mathrm{T}$ cell response by promoting recurrence [217]. The alternative role of Tregs in CRC may be due to changes in the immune microenvironment that causes the expression of ROR $\gamma \mathrm{t}$ by Tregs, which led to a switch from an anti-inflammatory to inflammatory role through IL-17 secretion [218]. Additionally, another study showed that Foxp3+ Tregs are enriched with of ROR $\gamma \mathrm{t}$ in mouse colon and lymphoid tissues [219,220].

\section{Immune Landscape Determinants and Predictors in GI Cancer}

Molecular subtypes and stratification identify the drivers of human cancer. This strategy has been used to profile the molecular, genetics, and immune composition of cancer, while an appropriate treatment regimen is assigned [221,222]. Notably, there have been a recent breakthrough using high-throughput next generation sequencing and consensus-based clustering technique to map the immune landscape to the genetics of tumors. Remarkably, CRC has been successfully stratified, and a consensus on four molecular subtypes (CMS) has been reached (see Figure 5).

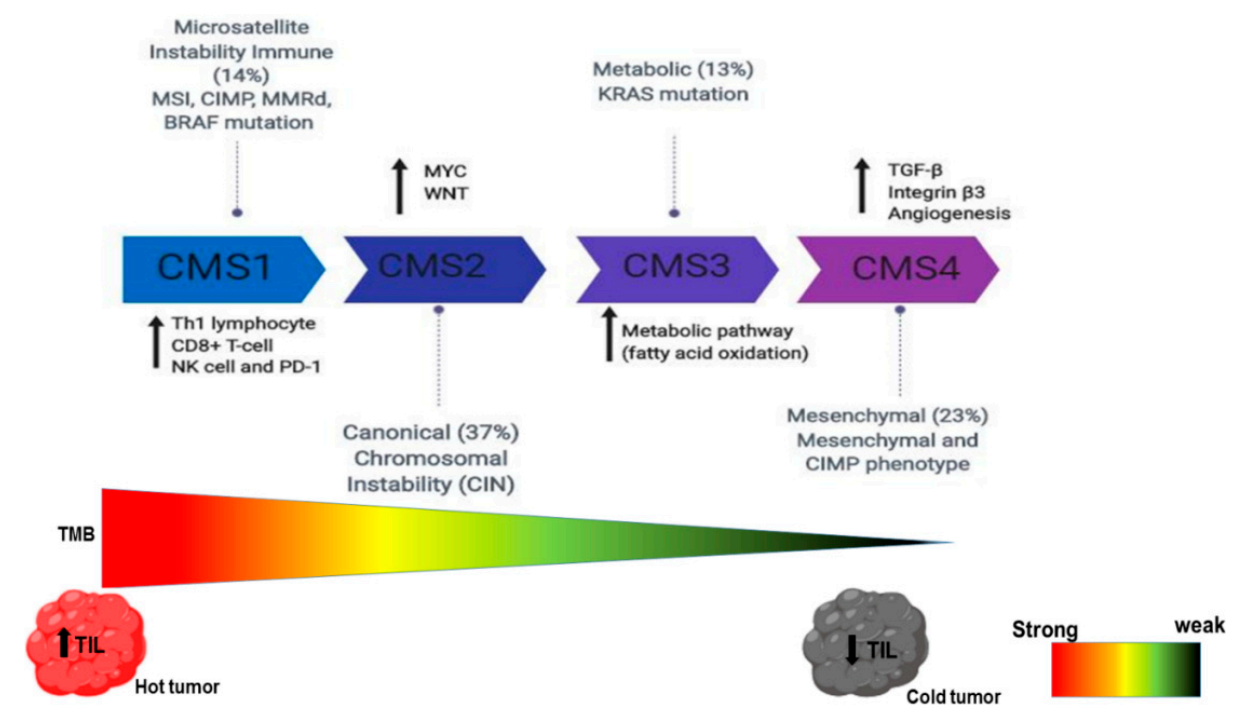

Figure 5. The consensus molecular classification (CMS) of CRC in correlation with tumor infiltrating lymphocyte (TIL) abundance. CMS1 is infiltrated with T helper 1 lymphocytes, CD8 ${ }^{+} \mathrm{T}$ cells, NK cells, PD-1, tumor mutation burden (TMB) and increased TIL as compared with other CRC subtypes. High TIL infiltration represent a hot tumor, which can be targeted with an immune checkpoint inhibitor, whereas reduction in TIL denotes a cold tumor.

CMS1 denotes microsatellite instability subtypes that are composed of microsatellite instability (MSI), CpG island methylator phenotype (CIMP), mismatch repair deficiency (MMrd), and BRAF mutations; CMS2 denotes canonical or epithelial subtypes consisting of chromosomal instability; CMS3 denotes a metabolic subtype consisting of KRAS mutations; and CMS4 denotes a mesenchymal subtype consisting of mesenchymal and CIMP phenotypes [223]. By contrast, there is little consensus on molecular subtypes in both pancreatic ductal adenocarcinoma (PDAC) and HCC, as these are still in their infancy. Similarly, tumors have also been classified based on tumor-infiltrated lymphocytes (TILs) and macrophages. The immune-inflamed or hot tumors are characterized by the high infiltration of immune cells; the immune-excluded is identified and characterized by immune cells which are trapped at the boundaries of the tumor; and immune-desert or cold tumor phenotypes are characterized by a complete absence of immune cells [224,225]. However, the limitation of the classification is that most studies have not simultaneously considered the boundaries and tumor core. The success of programmed cell death-1 and its ligand (PD-1/PD-L1) has been demonstrated in many cancers [226,227]. Nevertheless, some 
patients do not derive benefits from the immune checkpoint inhibitor (ICI). For instance, the failure of nivolumab in a phase III study has been reported [228,229], despite its success alongside pembrolizumab in phase II clinical trials $[230,231]$. Furthermore, a trial testing pembrolizumab in combination with dexamethasone (immunomodulatory agent) with either lenalidomide or pomalidomide in the treatment of patients with multiple myeloma was terminated due to death risk (US Food and drug administration alerts, 2018). An effective predictive biomarker is therefore needed to stratify patients who may respond to an immune checkpoint inhibitor. Several mechanistic studies have identified the determinants of tumor immune contextures as biomarkers for predicting the patient's response to immune checkpoint inhibitors (see Figure 6).

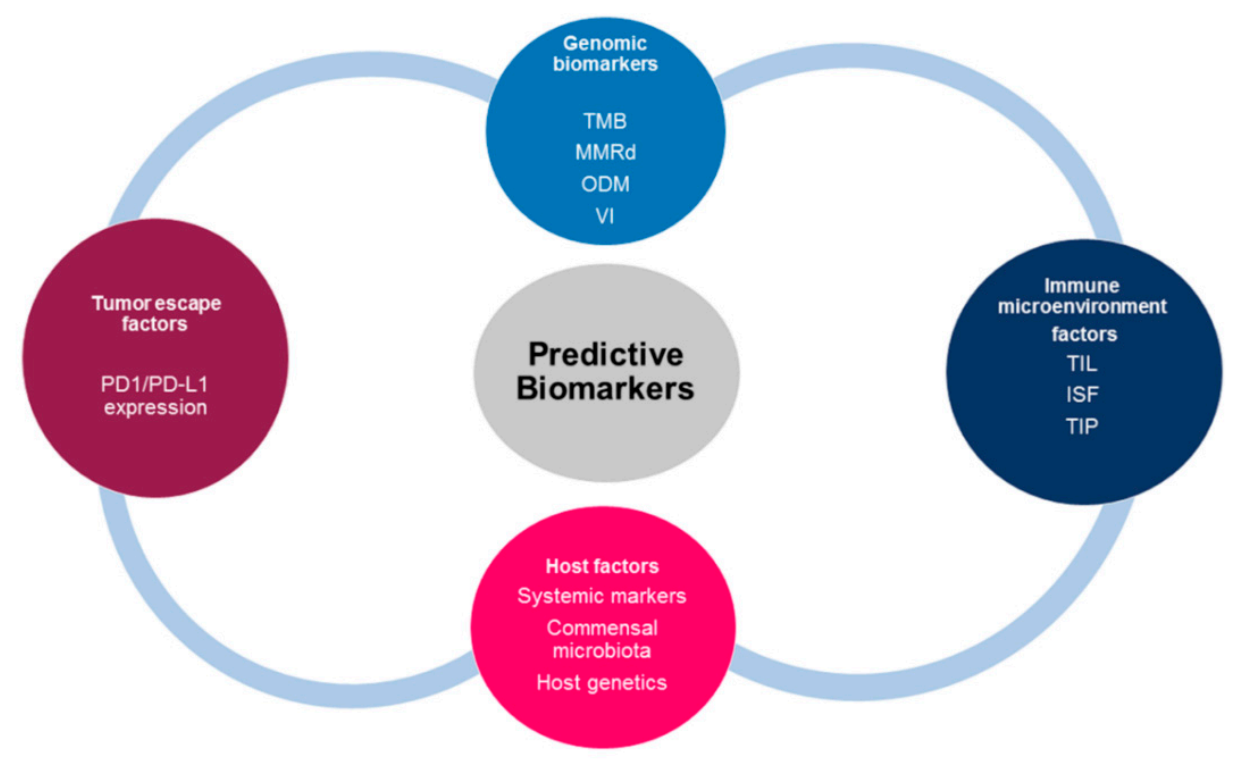

Figure 6. Emerging predictive biomarker of response to immune checkpoint inhibitor. The programmed cell-death 1 and its ligand (PD-1/PD-L1) are tumor escape factors used widely as predictive biomarkers for patient's response to immunotherapy. Other suggestive biomarkers include genomic, tumor-escape, immune-microenvironment and host factors. These factors include TMB (tumor mutation burden), MMrd (mismatch repair deficiency), VI (oncogenic viral infection), ODM (oncogenic driver mutation), TIL (tumor infiltrating lymphocyte), ISF (Immune suppressor factor) and tumor immune phenotype (TIP).

PD-L1 is critical in predicting patient's response to PD-1/PD-L1 inhibitor immunotherapy. Thus, PD-L1 expression using immunohistochemistry is the only approved biomarker widely employed to distinguish responders from non-responders [232]. However, there are limitations with the use of PD-L1 as a predictive biomarker. First, there have been contradictory results on the association between PD-L1 expression and immune checkpoint efficacy [233]. Furthermore, PD-L1-negative patients benefit from immune checkpoint inhibitor therapy [234]. Other limitations include non-standardized cutoff to access PD-L1 positivity, unreliable predictive ability in CRC and HCC [235], different detection techniques [236], and the types of cells expressing PD-1/PD-L1 molecule within the tumor [237]. Thus, it can be concluded that PD-L1 expression is not a one-size-fits-all biomarker. TIL is another predictor of immune checkpoint inhibitor efficacy and also a strong prognostic biomarker for some cancers regardless of the ICI. For example, the tumor-inflamed phenotype exhibits a better response to ICI due to the high infiltration of TILs within the stroma [238]. Surprisingly, some patients with a tumor-inflamed phenotype still do not derive benefit. A study showed that the early infiltration of regulatory $\mathrm{T}$ cells (Tregs) may hinder the cytotoxic effect of TIL [239]. It has been reported that mutations within cancer cells encode for neoantigens, recognized by T cells when presented by the MHC molecules [166]. In addition, the number of non-synonymous single nucleotide variants (nsSNVs), somatic copy numbers, and indels are hypothesized to be contributors to the tumor mutation burden (TMB). A high 
TMB observed in CRC and HCC positively correlates with PD-1/PD-L1 expression, whereas PDAC has the lowest TMB [240,241]. Conversely, a meta-analysis by Liu et al. [242] found no association between PD-1/PD-L1 and TMB in curative resected HCC. Evidence from both tumor samples and patients implicates V-domain Ig suppressor of T cell activation (VISTA) as the main inhibitory checkpoint expressed in PDAC [243]. Indeed, the elevated mutational burden and expression of cytotoxic T cells, NK cell infiltration, Th1 lymphocytes, and PD-1 due to enhanced neoantigens are hallmarks of the CMS1 subtype of CRC [221] (see Figure 5). A mutation per mega base of 17 or above has been reported to correlate with microsatellite instability (MSI-CRC) in CMS1 of CRC [244], although other studies have reported a variable TMB cutoff point [245]. Remarkably, 3\% of microsatellite stable (MSS-CRC) patients also benefit from a high TMB cutoff [246]. Similar results identify a correlation between TMB and immune checkpoint response in many cancer types [247]. Surprisingly, some patients with a high TMB do not respond to the immune checkpoint inhibitor and vice versa $[248,249]$. Contrary to reports on TMB and ICI response, a recent study utilized the quanTIseq deconvolution approach on 8000 cancer genome atlas (TCGA) tumor samples across 19 solid tumors and found that both mutation burden and tumor clonality heterogeneity are weakly associated with infiltrated $\mathrm{CD} 8^{+} \mathrm{T}$ cells [250]. However, this study reported a stronger association between CXCL9/CXCR3 and CD8 ${ }^{+}$ $\mathrm{T}$ cell infiltration. Tumor clonality also influences the response to the immune checkpoint inhibitor but does not contribute to mutational burden. Clonal mutation from homogenous tumors has been reported to enhance immune response more effectively than subclonal mutation from heterogeneous tumors [251]. Notably, MSI is a type of mismatch repair deficiency (MMRd) which generates indel and frameshift mutations. This stimulates neoantigens, leading to increased T cell infiltration with an improved response to the immune checkpoint inhibitor [252]. However, MMRd gives rise to subclonal neoepitopes that are less effective at generating a good response to ICI [251,253]. The mechanism by which MMRd generates a better response to ICI is not understood. The loss of tumor suppressor genes (TSG), oncogenic driver mutations, and oncogenic pathways (see Figure 7) have also been found to contribute to immune composition and immune checkpoint response.

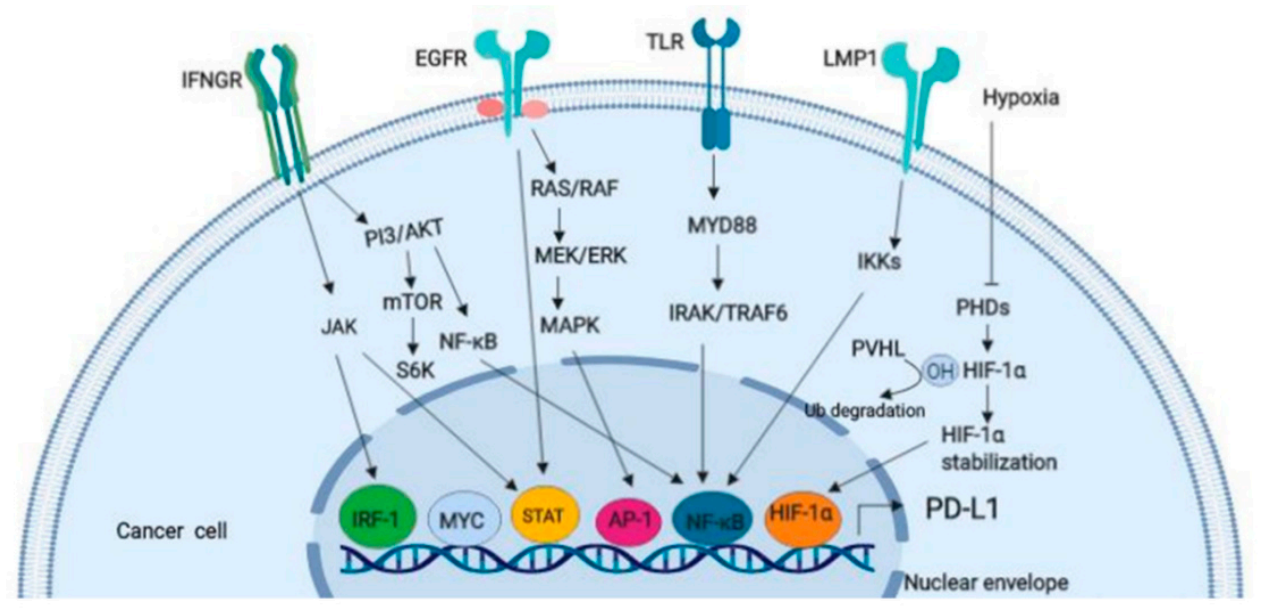

Figure 7. Signaling pathways for PD-L1 expression in cancer. Programmed death ligand-1 (PD-L1) is a cell surface receptor on cancer cells modulated by interferon gamma receptor (IFNGR), epidermal growth factor (EGFR), toll-like receptor (TLR), Epstein-Barr virus latent membrane protein (LMP1) and hypoxia.

Research has shown that driver oncogenes or a loss of TSG enhance immune suppression and attenuate immune responses in GI cancers. For example, a mutation in TP53 is associated with increased immunosuppressive cells (Tregs and T follicular helper) and immune checkpoint molecules (CTLA-4, PD-1 and T-cell immunoglobulin and mucin domain-containing protein 3 (TIM-3) in HCC [254]. P53 loss decreased cytotoxic CD8 ${ }^{+} \mathrm{T}$ cells and increased Th1/2 shifts, which promote gemcitabine resistance, thus leading to a reduced survival in PC mouse models [255]. Similarly, mutation in P53-induced TAM 
population and Tregs leads to tumor progression [256]. Another study showed a positive correlation between P53 loss or KRAS mutation alone or co-occurrence of both mutations and ICI response was reported in lung adenocarcinoma [257]. Consistently, PD-L1 expression is higher and correlates with P53 mutation in NSCLC than in CRC [258]. In addition, a positive correlation between KRAS mutation and PD-1/PD-L1 was found in PC [259]. Contrarily, a lower efficacy in response to anti-PD-1 was reported in CRC with a KRAS mutation [260]. Other clinical studies on NSCLC reported that epidermal growth factor receptor (EGFR) mutations and anaplastic lymphoma kinase (ALK) rearrangements, KRAS, and BRAF do not influence the efficacy of the immune checkpoint inhibitor [261-263]. Furthermore, Balli et al. [248] reported an inverse correlation between NOTCH2-, MYC-, and fibroblast growth factor receptor-1 (FGFR1)-amplified tumors and cytolytic T cell response rather than mutation load in pancreatic tumors. Further research has revealed the modulatory effect of microbiota on the efficacy of ICI. For instance, Sivan et al. [264] identified a relationship between Bifidobacterium and the PD-1 inhibitor in a mouse model of melanoma. Bifidobacterium enhanced anti-PD-1 efficacy by augmenting dendritic cell function and $\mathrm{CD} 8^{+} \mathrm{T}$ cell priming. Similarly, patients with Faecalibacterium had longer progression-free survival and higher TILs compared with patients who had a lower abundance of this strain of bacteria [265]. Furthermore, the over-presentation of Ruminococcaceae, Faecalibacterium, and Clostridiales in peripheral blood positively correlates with $\mathrm{CD} 8^{+} \mathrm{T}$ cells while Bacteroidales correlates with MDSCs and Tregs [265]. Routy et al. [266] compared clinical outcomes when patients were treated with the PD-1 inhibitor in combination with or without antibiotics. Treatment with antibiotics and PD-1 resulted in shorter overall survival and progression-free survival alone or with the CTLA-4 inhibitor. By contrast, bacterial ablation upregulated T cell and PD-1 expression in a mouse model of PDAC [16]. As opposed to PD-1, CTLA-4 efficacy is determined by Bacteroides fragilis. The colonization of $B$. fragilis in germ-free mice improved the anti-tumoral response of anti-CTLA-4 therapy [267]. Other emerging predictive biomarkers include immune microenvironment factors, host factors (see Figure 6).

Additionally, the carcinoembryonic antigen (CEA) and carbohydrate antigen 19-9 (CA19-9) are glycoproteins and cancer antigens mostly found elevated in solid tumors [268]. CEA and CA-19-9 are widely used as the prognostic and/or predictive biomarkers for the detection and management of adenocarcinoma including GI cancer. A recent study showed that serum CA-19-9 predicts PC in acute pancreatitis patients [269]. Similarly, CEA level is a recommended prognostic biomarker according to the national comprehensive cancer network (NCCN) guidelines in CRC. Based on the sensitivity, the clinical use of these prognostic biomarker is controversial. Notably, these cancer antigens are prerequisite for clinical therapy design for bispecific T cell engagers (BiTES) (CD3*CEA), anti-CEA Chimeric antigen receptor $\mathrm{T}$ cell (CAR-T), anti-epithelia cell adhesion molecule (EPCAM) CAR-T and several others. These are currently being tested for their efficacy in clinical trials, whereas some of them showed promising result in clinical trials (as discussed in Section 5).

\section{Progress and Current Immunotherapeutic Approaches in GI Cancers}

\subsection{Adoptive T-Cell Therapy}

\subsubsection{Chimeric Antigen Receptor T Cells}

The chimeric antigen receptor $\mathrm{T}$ cell (CAR-T) is a major breakthrough in oncology. CAR-Ts are genetically engineered and designed to recognize tumor antigens in the absence of MHC presentation through the expression of CARs. The CARs fuses an antibody-binding domain to the signaling domain linked to the co-stimulatory domain $[270,271]$. The only approved CAR-T is anti-CD19 for the treatment of B-cell lymphoma, which targets the co-stimulatory molecule CD19 in B-cell lymphoma and leukemia [272]. However, a tolerable side effect may occur as well as relapse due to CAR-binding epitopes [270,273]. Other limitations from CAR-T treatment include exhausted CAR-T and poor trafficking into the tumor $[274,275]$. Several attempts to treat solid tumors with CAR-T therapy have been unsuccessful due to the nature of the tumor microenvironment as well as contributing factors such as hypoxia, which leads to toxicity in treated patients [276-278]. Furthermore, evidence from 
pre-clinical studies has identified loopholes, and strategies that aim to address setbacks from CAR-T treatment in solid tumors have been extensively discussed [279-281]. Notably, therapeutic approaches such as combination strategies and the modification of CAR-T have been implemented. Several of them are undergoing clinical trials (NCT02729493, NCT03323944, NCT03638206) (see Table 1).

For instance, a recently completed phase 1 clinical trial of anti-glypican-3 (GPC3) CAR-T, evaluating its efficacy and safety for 13 patients with R/R (relapse/refractory) HCC, yielded promising results. All patients tolerated the treatment; one patient had a serious adverse event (SAE) grade 3 fever. Patients treated without lymphodepletion conditioning had progressive disease after receiving anti-GPC3 CAR-T. Conversely, treatment with lymphodepletion conditioning results in one partial response-three patients had a stable disease (SD), two had a progressive disease, and one death was reported in the stable disease group after 108 days [282]. Another completed phase 1 trial showed that CEA CAR-T was well tolerated in CRC patients. Seven patients who previously had progressive disease had a SD, with two of the seven patients having a SD for 30 weeks. Two patients had tumor shrinkage, and CEA was reduced in the blood of most patients. Lastly, CAR-T was found to proliferate and persist in the patient's blood after the second infusion [283]. (see Table 2). 
Table 1. Clinical trials of various adoptive immunotherapies in gastrointestinal (GI) cancer.

\begin{tabular}{|c|c|c|c|c|c|c|c|}
\hline Cancer Type & Start Year & No of Participants & Site of Trial & Agents & Phase & $\begin{array}{l}\text { Clinical } \\
\text { Trials Gov } \\
\text { Number }\end{array}$ & $\begin{array}{l}\text { Recruitment } \\
\text { Status }\end{array}$ \\
\hline \multicolumn{8}{|c|}{ CAR-T Therapies } \\
\hline Liver neoplasms & 2015 & 25 & China & EPCAM CAR-T cells & N/A & NCT02729493 & Yes \\
\hline Metastatic cancer & 2012 & 15 & US & Mesothelin CAR-T & $\mathrm{I} / \mathrm{II}$ & NCT01583686 & Terminated \\
\hline HCC & 2018 & 50 & China & c-Met/PD-L1 CAR-T & Ia & NCT03672305 & Not yet \\
\hline Advanced HCC & 2015 & 13 & China & Anti-GPC3 CAR-T & I & NCT02395250 & Completed \\
\hline Malignancies & 2018 & 73 & China & Autologous CAR-T/TCR & I/II & NCT03638206 & Yes \\
\hline PC & 2017 & 18 & US & huCART-meso cells & I & NCT03323944 & Yes \\
\hline $\mathrm{HCC}$ & 2019 & 14 & US & GPC3-CAR-T + Cytoxan + Fludarabine & I & NCT02905188 & Yes \\
\hline Malignant solid tumor & 2019 & 30 & China & Nectin 4 /FAP CAR-T & I & NCT03932565 & Yes \\
\hline PC & 2018 & 10 & China & CAR-T-meso cells & N/A & NCT03638193 & Yes \\
\hline $\begin{array}{c}\text { PC } \\
\text { CEA + liver metastases }\end{array}$ & 2019 & 6 & US & CAR2Anti-CEA CAR-T & $\mathrm{Ib}$ & NCT03818165 & Yes \\
\hline $\begin{array}{l}\text { HCC/Metastatic } \\
\text { colorectal and PC }\end{array}$ & 2016 & 20 & China & CAR-T & $\mathrm{I} / \mathrm{II}$ & NCT02959151 & Unknown \\
\hline EPCAM + cancer & 2017 & 60 & China & CAR-T & I/II & NCT03013712 & Yes \\
\hline HCC & 2017 & 18 & China & ET1402L1-CAR-T & I & NCT03888859 & Yes \\
\hline Metastatic CRC & 2018 & 20 & China & EGFR/CAR-T & I & NCT03542799 & Not yet \\
\hline Advanced malignancies & 2015 & 20 & China & Anti-CD133 CAR-T & I & NCT02541370 & Unknown \\
\hline \multicolumn{8}{|c|}{ Tumor-Infiltrating Lymphocyte Therapies } \\
\hline Metastatic cancer & 2010 & 332 & US & $\begin{array}{l}\text { TIL + Aldesleukin + Cyclophosphamide } \\
\text { + Fludarabine + Pembrolizumab }\end{array}$ & II & NCT01174121 & Yes \\
\hline Colorectal cancer & 2019 & 20 & China & Anti-PD-1 activated TIL + Xelox & I/II & NCT03904537 & Yes \\
\hline $\begin{array}{l}\text { Advanced refractory } \\
\text { solid tumor }\end{array}$ & 2017 & 40 & China & $\begin{array}{c}\text { Neoantigen Reactive T Cells (NRTs) + } \\
\text { PD-1 }\end{array}$ & $\mathrm{I} / \mathrm{II}$ & NCT03171220 & Yes \\
\hline Advanced solid cancer & 2019 & 240 & US & TIL + Cyclophosphamide + Fludarabine & II & NCT03935893 & Not yet \\
\hline \multicolumn{8}{|c|}{ CIK Therapies } \\
\hline PC & 2013 & 47 & China & $\mathrm{DC} / \mathrm{CIK}+\mathrm{S} 1$ & I/II & NCT01781520 & Completed \\
\hline PC & 2018 & 90 & China & $\begin{array}{l}\text { CIK + Anti- CD3-MUC1 bispecific } \\
\text { antibody }\end{array}$ & II & NCT03509298 & Yes \\
\hline CRC & 2012 & 46 & China & CIK + Folfox 4 & IV & NCT03084809 & Completed \\
\hline Colon cancer & 2019 & 20 & Iran & Autologous CIK & I/II & NCT03329664 & Not yet \\
\hline Metastatic CRC & 2017 & 28 & Korea & Immuncell-LC & II & NCT03220984 & $\begin{array}{c}\text { Enrolling by } \\
\text { invitation }\end{array}$ \\
\hline HCC & 2015 & 55 & China & Autologous CIK & I/II & NCT03124498 & Unknown \\
\hline Resected liver cancer & 2008 & 200 & China & CIK & III & NCT00769106 & Completed \\
\hline Liver transplant in HCC & 2019 & 18 & Korea & Immuncell-LC & I/II & NCT03983967 & Yes \\
\hline
\end{tabular}


Table 1. Cont.

\begin{tabular}{|c|c|c|c|c|c|c|c|}
\hline Cancer Type & Start Year & No of Participants & Site of Trial & Agents & Phase & $\begin{array}{l}\text { Clinical } \\
\text { Trials Gov } \\
\text { Number }\end{array}$ & $\begin{array}{l}\text { Recruitment } \\
\text { Status }\end{array}$ \\
\hline \multicolumn{8}{|c|}{ iNKT Therapies } \\
\hline Advanced solid tumor & 2017 & 40 & China & iNKT cells $+\mathrm{CD} 8^{+} \mathrm{T}$ cells & I/II & NCT03093688 & Yes \\
\hline \multicolumn{8}{|c|}{ Bispecific $T$ cell engager } \\
\hline PC & 2015 & 2 & US & anti-CD3 $\times$ anti-EGFR, IL- $2+$ GM-CSF & I/II & NCT02620865 & Active, NR \\
\hline
\end{tabular}

Abbreviations: EGFR, epidermal growth factor receptor; iNKT, invariant natural killer-T cell; CIK, cytokine induced killer cell; GM-CSF, granulocyte macrophage-colony stimulating factor; NRT, Neoantigen Reactive T Cells; MUC-1, mucin-1; TIL, tumor infiltrating lymphocyte; GPC3, glypican-3; DC, dendritic cell; EPCAM, epithelia cell adhesion molecule; NR, not recruiting; CEA, Carcinoembryonic Antigen; CART-T, chimeric antigen receptor-T cell; TCR, T cell receptor.

Table 2. Clinical trial efficacy result of selected immunotherapies in GI cancer.

\begin{tabular}{|c|c|c|c|c|c|c|}
\hline Cancer Type & Immunotherapy & No of Participants & Phase & Clinical Outcome & Immune Response Adverse Effect & Reference \\
\hline & & & CAR-T & & & \\
\hline HCC & Anti-GPC3 CAR-T & 13 & I & 1 PR, $3 \mathrm{SD}, 2 \mathrm{PD}$ & SAE grade 3 fever in $1 \mathrm{pt}, 1$ death & [282] \\
\hline CRC & CEA CAR-T & 10 & I & $7 \mathrm{SD}, 2 \mathrm{SD}>30 \mathrm{wk}, 2 \mathrm{TS}$ & No IrAE & [283] \\
\hline PC & HER2 CAR-T & 11 & I & PFS 4.8 months, 1 PR, 5 SD & Reversible toxicities, mild to moderate & [284] \\
\hline Advanced metastatic cancer & CD133 CAR-T & 23 & I & PFS 5 months, 3PR, 14SD & Controllable toxicities & [285] \\
\hline \multicolumn{7}{|c|}{ Immune Checkpoint Inhibitor } \\
\hline Advanced GC and CRC & Regorafenib +nivolumab & 50 & $\mathrm{Ib}$ & $\begin{array}{l}38 \% \text { ORR, 3PR in GC. } 44 \% \\
\text { RR(GC), 29\% MSS(CRC) }\end{array}$ & Grade $3 / 4$ toxicity in $17 \mathrm{pts}$ & [286] \\
\hline CRC & $\begin{array}{l}\text { Atezolizumab/+ or without } \\
\text { cobimetinib versus regorafenib }\end{array}$ & 363 & III & $\begin{array}{l}\text { mOS } 8.87 \text { months } \\
\text { (combination group) }\end{array}$ & SEA in $40 \%$ of pts (combination group) & [287] \\
\hline \multicolumn{7}{|c|}{ NK Cell Therapy } \\
\hline GI cancer & $\begin{array}{l}\text { Allogenic NK therapy + } \\
\text { Cetuximab }\end{array}$ & 9 & I & $2 \mathrm{SD}, 1 \mathrm{PR}, \mathrm{I} \mathrm{DR}$ & No DLT & [288] \\
\hline \multicolumn{7}{|c|}{ Cancer Vaccine } \\
\hline Metastatic PC & G-VAX/CRS-207 & 93 & II & $\begin{array}{l}\text { OS arm A } 6.1 \text { months vs. arm } \\
\text { B } 3.9 \text { months }\end{array}$ & Grade $3 / 4$ toxicity & [289] \\
\hline \multicolumn{7}{|c|}{ BiTES } \\
\hline Refractory solid tumor & EpCAM/CD3 BiTES & 65 & I & $\begin{array}{c}18 \mathrm{SD}, 17 \mathrm{BR} \text { of } \mathrm{SD}, 28 \mathrm{PD}, 1 \\
\text { unconfirmed PR }\end{array}$ & $\begin{array}{c}\text { DLT in } 15 \mathrm{pts} \text {, Grade } 3 / 4 \text { toxicity in } 95 \% \\
\text { pts }\end{array}$ & [290] \\
\hline \multicolumn{7}{|c|}{ Stroma-Targeted Therapies } \\
\hline $\begin{array}{c}\text { PDAC } \\
\text { Advanced metastatic solid tumor }\end{array}$ & $\begin{array}{l}\text { Pegylated IL-10 + Folfox } \\
\text { NKTR-214 }\end{array}$ & $\begin{array}{l}353 \\
28\end{array}$ & $\begin{array}{c}\mathrm{I} / \mathrm{lb} \\
\mathrm{I}\end{array}$ & $\begin{array}{c}15.5 \% \text { ORR, } 10.5 \% \text { CR } \\
\text { SD in } 14 \text { pts, TR in } 35 \% \text { of pts }\end{array}$ & $\begin{array}{l}\text { Grade } 3 / 4 \text { TrAEs, Grade } 1 / 2 \text { neuropathy } \\
\text { Grade } 3 \operatorname{TrAE} \text { in } 21.4 \% \text { of pts }\end{array}$ & $\begin{array}{l}\text { Ongoing } \\
\text { [291] }\end{array}$ \\
\hline Advanced metastatic solid tumor & Emactuzumab/ + paclitaxel & 217 & I & $\begin{array}{l}7 \% \text { ORR in combined } \\
\text { therapy, no anti-tumor effect }\end{array}$ & No toxicity & [292] \\
\hline
\end{tabular}

Abbreviations: ORR, objective response rate; OS, overall survival; PR, partial response; SD, stable disease; PD, progressive disease; $\mathrm{CR}$, complete response; $\mathrm{PFS}$, progression free survival; $\mathrm{mOS}$, mean overall survival; Rd, dissociated response; DLT, dose limiting toxicities; SAE, serious adverse event; IrAE, immune related adverse event; TrAE, treatment related adverse effect, PDAC, pancreatic ductal adenocarcinoma; TR, tumor reduction; Pts, patients; TS, tumor shrinkage. 
A different CAR-T approach has recently been developed that can eliminate cancer cells with ET1402L1 T cells in HLA-A* 02:01 restricted $\mathrm{AFP}^{+}$in HCC [293]. This approach has been found to counteract tumor growth in pre-clinical studies and is currently being tested for safety and efficacy in ongoing trials (NCT03888859). However, CAR-T therapy such as anti-mesothelin CAR-T (NCT01583686) in metastatic PC has been terminated for unknown reasons.

\subsubsection{Tumor-Infiltrating Lymphocytes}

TILs are employed in ACT, a procedure in which $\mathrm{T}$ cells are derived from resected metastatic tumor or blood and expanded in vitro in the presence of IL-2, anti-CD3 antibodies, and irradiated autologous or allogenic feeder cells [294]. The final product is infused into lymphodepleted patients to inhibit tumor progression $[295,296]$. The modification of the tumor-reactivity selection step results in the so called "young TIL protocol," which is a shorter process [297]. Recent advances involve high-throughput genetic sequencing to identify the non-synonymous mutation and subsequent synthesis of mutation peptide pulsed with DCs. The isolated TILs from the tumor are co-cultured with pulsed DC peptide, recognized by the subsequent expansion of T cells [298]. A higher percentage of TILs within tumor predicts survival in many cancer patients, including those with GI cancer [299,300]. Tran et al. [301] found that TILs derived from nine out of 10 patients in metastatic GI cancer contained CD4 ${ }^{+} \mathrm{T}$ cells and $\mathrm{CD}^{+} \mathrm{T}$ cells that recognize one to three neoepitopes from somatic mutation. In addition, TILs adoptive cell therapy yielded 50\% ORR and 13\% complete response (CR) in melanoma patients [296], which surpass responses from immune checkpoint inhibitors in reported cases. Even the most difficult forms of breast cancer; triple negative breast cancer (TNBC) and human epidermal growth factor (HER2) was successfully treated with TILs [302,303]. Promising results have also been reported in cholangiocarcinoma after infusion with $\mathrm{CD}^{+} \mathrm{T}$ cells that recognized the Erbb2 binding protein ERBB2IP epitope [304] and HLA-C*8:02 in restricted KRAS G12D lung metastasis CRC [305]. Interestingly, $\mathrm{CD} 8^{+}$neoantigen T cells specific to SMAD5 and mucin-4 (MUC4) epitopes, $\mathrm{CD} 4^{+}$and $\mathrm{CD} 8{ }^{+}$memory $\mathrm{T}$ cells specific to KRASG12D and KRASG12V, respectively, have been isolated from peripheral blood of epithelial cancer patients [306]. Future clinical trials will test neoantigen-specific T cells and TCRs for the P53 mutation in metastatic cancer [307]. Despite the efficacy of TIL therapy, the limitations of this approach include the poor survival of $\mathrm{T}$ cells, the poor efficiency of the method used to detect neoantigen reactive $T$ cells, and the derivation of terminally differentiated exhausted $T$ cells that express immune checkpoint protein [308,309]. More recent studies have reported strategies that can improve the efficacy of TIL treatment, such as reprogramming exhausted differentiated T cells using the Sendai virus to transduce octamer binding protein-3/4 (OCT3/4), sex determining region-Y2 (SOX2), kruppel-like factor (KLF4), and c-MYC to induced pluripotent stem cell (iPSC) [310]. In addition, the enhancement of neoantigen reactive $\mathrm{T}$ cells through the enrichment of PD-1-expressing T cells by using a micro well culture method to prevent the overgrowth of non-reactive T cells [298]. The prevalence and application of TILs in targeting KRASG12D in patients with gastrointestinal cancer have been a subject of debate [311]. Treatment with TILs is currently undergoing clinical trials (see Table 1), and the results are eagerly awaited.

\subsubsection{CIK}

The efficacy of cytokine induced killer cells (CIK) therapy has been demonstrated in gastrointestinal tumors such as CRC, HCC, and PC. In addition, combination therapy has also been reported to enhance efficient cytotoxic and anti-tumor activity of CIK. Consequently, CIK has been used in combination treatment with dendritic cells (DCs), cytokines, immune checkpoint inhibitors, chemotherapy, chimeric antigen receptors, antibodies, and nanoparticles. These combination strategies have produced encouraging results. For instance, pre-clinical and clinical studies have shown that CIK in combination with DCs exhibited better efficacy than CIK monotherapy in HCC and post-trans catheter arterial chemoembolization (TACE) HCC [312-314]. A study on 67 patients reported partial remission in five patients and a stable disease in 29 patients with a decreased migration and proliferation in cancer 
cells. Cytokine induced killer cells-dendritic cells(CIK-DC) combined with sorafenib also improved patients' overall survival rate with no adverse effect in advanced HCC [315]. Similarly, CIK-DC also showed improved overall survival of five years and disease-free survival in CRC [316-318]. The transfusion of autologous CIK and a meta-analysis of DC-CIK showed an improved overall survival rate for advanced PC $[319,320]$. Furthermore, the clinical efficacy of adjuvant therapy with activated CIK treatment showed an increased median recurrence-free survival (RFS) time of 44 months compared with the reccurrence free survival (RFS) of patients receiving curative treatment for liver cancer [321]. Several clinical trials testing the efficacy and safety of CIK-DC in combination with immune checkpoint inhibitors, chemotherapy, and others are currently ongoing. One of these will examine the outcome of combination therapy with CIK-DC plus Anti-PD-1 in refractory solid tumors, including HCC and CRC (NCT02886897); the efficacy and safety of adjuvant CIK in HCC patients undergoing liver transplantation (NCT03983967); and intermediate stage HCC who have undergone TACE (NCT02856815).

\subsection{Bispecific T-Cell Engagers}

Bispecific T cell engagers (BiTEs) that recognize cancer stem cell (CSC) antigens (CD19) and antigen-binding domains of antibodies (CD3) attract CSCs while promoting T cell-induced cytotoxicity as well as redirecting the effector function of a number of immune cells [322,323]. The only approved BiTE is Blinatumomab, which is given as a continuous infusion and results in a rare remission rate in patients [323]. Phase 1 clinical trials of EpCAM/CD3 T cell engager (Solitomab) in solid tumors have shown an anti-tumor effect with a significant side effect [290]. Furthermore, a phase 1 study of CEA*CD3BiTES was abruptly terminated due to the detection of BiTES antibodies in patients treated with a high dose, with disease progression in $73 \%$ of patients with advanced gastrointestinal cancer [324].

\subsection{Cancer Vaccines}

Cancer vaccines are developed to specifically target tumor-associated antigens (TAAs), virus-associated antigens, cancer germline antigens, or tumor-specific antigens (TSAs) (neoantigen). Despite treatment with an immune checkpoint inhibitor, cancer-specific immune responses remain suboptimal, leaving options for alternatives and new therapeutic approaches. Neoantigens expressed by mutated cancer cells can generate optimal $\mathrm{CD} 4^{+}$and $\mathrm{CD} 8^{+} \mathrm{T}$ cell responses [325]. A recent study reported the stimulatory effect of a peptide neoantigens vaccine on $\mathrm{CD} 4^{+}$rather than on $\mathrm{CD} 8^{+} \mathrm{T}$ cell responses [326,327]. Remarkably, a neoantigen-based vaccine that contains up to 20 neoantigen peptides that simultaneously targets multiple proteins showed promising results [328,329]. However, a study showed that the multipeptide vaccine failed to improve survival rates [330]. Similarly, a DNA vaccine that targets enolase-1 (ENO1) in genetically engineered mice with PDAC showed promising results but did not completely eradicate tumor growth [331]. Nevertheless, combination strategies have been shown to improve the efficacy of the ENO1 DNA vaccine in animal model. In addition, a multipeptide HCC vaccine IMA970A (HepaVac-101) with a CV8102 adjuvant is currently being tested in phase I/II clinical trials for very early and intermediate stage HCC positive with HLA haplotype (NCT03203005). The vaccine is composed of 16 peptide cocktails, with seven peptides restricted to HLA-A*02, five to HLA-A*24, and four to HLA class II. Of particular clinical relevance was a recent finding that the replication-deficient human type 5 recombinant adenovirus (Ad5) vaccine encoding guanylyl cyclase C (GUCY2C) fused to the PAn DR Epitope (PADRE) (Ad5-GUCY2C-PADRE) vaccine yielded positive results in the phase 1 clinical trial of early CRC patients [332]. The vaccine stimulated optimal CD8 ${ }^{+} \mathrm{T}$ cell responses, while $\mathrm{CD} 4^{+} \mathrm{T}$ cells were eliminated by self-tolerance, a condition known as "split tolerance" in the absence of neutralizing antibodies to the viral vector. Oncolytic viruses (OVs) are genetically engineered DNA viruses. OVs selectively infect highly replicative tumor cells by lytic cell destruction and dendritic cell activation through GM-CSF to stimulate T cell responses. OVs include adenoviruses, herpes simplex viruses, vaccinia virus, and vesicular stomatitis virus. OVs activate 
retinoic acid inducible gene-1/stimulator of interferon gene (RIG-1/STING) and TLR pathways [333,334]. Therefore, STING and TLR agonists are now being tested in clinical trials alone or in combination with immunotherapies. The oncolytic virus T-vec has been shown in all phases of clinical studies to be tolerable for patients with various types of cancer including GI cancer, and hence, its approval in melanoma [335-338]. Additionally, OV in combination with the CTLA4 blockade has been shown to be effective in melanoma [339]. By contrast, a combination approach with chemotherapy (gemcitabine) showed limited efficacy in oncolytic adenovirus-treated PC (NCT02045589) [340]. Furthermore, a recent study showed that OV Reo inhibits viral-induced oncogenic drive and tumor mutation burden in hepatitis C virus (HCV)-HCC [341]. A phase 1 study assessing the safety of an autologous cancer vaccine showed no significant side effects in 30 advanced solid tumors, including CRC. The study reported $23 \mathrm{SD}$ out of 27 and one progressive disease (PD) after first vaccination [342]. Finally, small anticancer molecules have also been used as a potent sensitizers of tumor cells for the improvement of oncolytic potential [343].

\subsection{Checkpoint Inhibitors}

Immune checkpoint inhibitors have been used successfully in treating a wide range of cancers with the exception of GI cancers [344,345]. Checkpoint molecules serve as "brakes" which inhibit the cytotoxic effect of $\mathrm{T}$ cells. The first approved checkpoint inhibitors are ipilimumab, an inhibitor of CTLA-4, and prembolizumab, which inhibits programmed cell death protein 1 (PD-1) [346,347]. Recently, several studies have focused on critical components and immune contexture by tumor stratification in predicting therapeutic outcomes across various cancers. For instance, tumors with a high mutation burden are better targets of immune checkpoints due to the highly expressed tumor antigen $[223,348]$. Despite the enhanced mutational burden, some patients remained unresponsive to immune checkpoint therapies [248]. Several mechanistic studies have identified the involvement of multiple immunosuppressive pathways [349,350]. Hence, the therapeutic blockade of TIGIT, VISTA, LAG-3, and TIM-3 are therefore now under investigation. Several strategies are currently piggy-backed on the success of checkpoint inhibitors [325]. Hence, the use of a combination therapy with checkpoint inhibitors (see Table 3).

Currently, ongoing studies are testing the safety and efficacy of immune checkpoint inhibitors and sorafenib in advanced HCC, whereas gemcitabine in combination with checkpoint blockade PDL-1 is being evaluated for the treatment of PC. Furthermore, combinations of radio frequency ablation, cyoablation, or TACE and CTLA-4 inhibitor in advanced HCC shows promising results [351], and phase 2 is currently ongoing. Notably, a combination of regorafenib and nivolumab (anti-PD-1) in patients with advanced CRC yielded a $29 \%$ response rate, a reduced FoxP3hiCD45RA-Tregs fraction, a manageable safety profile, and an anti-tumor effect [286]. By contrast, phase 3 studies on the combination of cobimetinib or atezolizumab plus regorafenib failed to improve overall survival rates, and three treatment-related deaths was reported [287]. 
Table 3. Clinical trials of other immunotherapies in GI cancer.

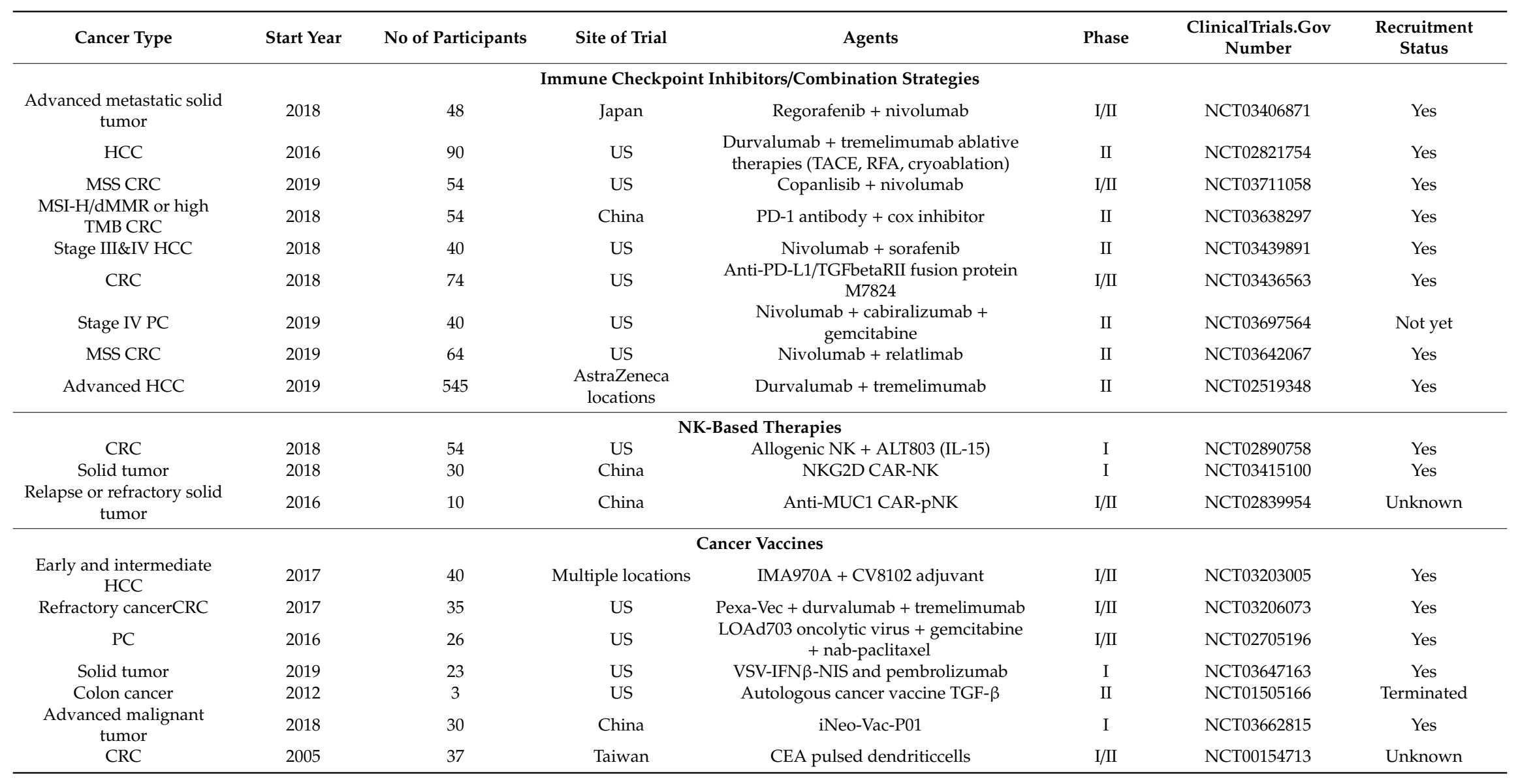


Table 3. Cont.

\begin{tabular}{|c|c|c|c|c|c|c|c|}
\hline Cancer Type & Start Year & No of Participants & Site of Trial & Agents & Phase & $\begin{array}{c}\text { ClinicalTrials.Gov } \\
\text { Number }\end{array}$ & $\begin{array}{c}\text { Recruitment } \\
\text { Status }\end{array}$ \\
\hline \multicolumn{8}{|c|}{ Stroma-Directed Therapies } \\
\hline MSS CRC & 2018 & 20 & Germany & CCR5 inhibitor + pembrolizumab & I & NCT03274804 & Active, NR \\
\hline Malignant solid tumor & 2019 & 30 & China & Nectin 4/FAP CAR-T & I & NCT03932565 & Yes \\
\hline PC & 2008 & 12 & US & $\begin{array}{l}\text { G-VAX vaccine + cyclophosphamide + } \\
\text { pembrolizumab, + anti-CSF-1R } \\
\text { monoclonal antibody IMC-CS4 }\end{array}$ & I & NCT03153410 & Yes \\
\hline Metastatic PC & 2017 & 566 & Multiple locations & Pegylated IL- $10+$ folfox & III & NCT02923921 & Yes \\
\hline Metastatic PC & 2017 & 9 & US & IL-12 gene therapy & I & NCT03281382 & Yes \\
\hline HCC & 2018 & 35 & China & Chiauranib & 1 & NCT03245190 & Yes \\
\hline Advance cancer & 2018 & 280 & Multiple locations & Anti-IL-8 + Nivolumab & I/IIa & NCT03400332 & Yes \\
\hline
\end{tabular}

Abbreviations: HCC, hepatocellular carcinoma; TACE, transarterial chemoembolization; RFA, radiofrequency ablation; MSS, microsatellite stable; MSI-H, microsatellite instability; dMMR,

mismatched repair deficiency; TMB, tumor mutation burden; PD-1, programmed cell death-1; COX, cyclo-oxygenase; CRC, colorectal cancer; PC, pancreatic cancer; NK, natural killer; CAR, chimeric antigen receptor; CAR-NK, chimeric antigen receptor -natural killer; MUC-1, mucin 1; CEA, Carcinoembryonic Antigen; FAP, fibroblast activation protein; CCR2, C-C chemokine receptor type 2; C-C chemokine receptor type 5; CSF-1R,colony stimulating factor-1 receptor; IL-interleukin; TGF- $\beta$, transforming growth factor; CAR-T; chimeric antigen receptor-T cell; VSV-IFN $\beta$-NIS, Oncolytic VSV engineered to express interferon-beta (IFN $\beta$ ) and the sodium iodide symporter (NIS); NKG2D, Natural killer group 2 member D. 


\subsection{NK Cell-Based Therapies}

NK cell express inhibitory molecules such as KIR (killer cell immunoglobulin-like receptor), NKG2A, and TIGIT. Similarly, a subset of NK cells has been reported to express checkpoint molecule (PD-1) [352]. Monoclonal antibodies targeting these molecules are currently being tested alone or in combination with other immunotherapeutic therapies $[353,354]$. Potent stimulators of the cytotoxic effect of NK cells includes IL-2 and IL-15. Allogeneic NK cell transfer is widely used in clinical trials due to its promising results [355]. For instance, a study reported that irreversible electroporation in combination with allogeneic NK cells improves the median overall survival in stage IV HCC patients [356]. Similarly, the combination of irreversible electroporation and allogeneic NK cell increases progression free survival and overall survival in stage III/IV PC [357]. Another study showed that combination of either 5-fluorouracil or oxaliplatin with adoptive NK cell increases five years' progression free survival and overall survival with no severe adverse effect in CRC [358]. A phase 1 study testing the combination of trastuzumab or cetuximab with adoptive NK cell therapy is well tolerated with four stable diseases; three of which show a decreased tumor size, and two out of the six treated patients had progressive diseases [359]. Furthermore, the use of CAR-NK in solid tumors is still in its infancy, as most studies are from preclinical studies and early clinical trials. Pre-clinical studies of CAR NK-92 targeting receptor tyrosine-protein kinase erbB-2 (ErbB2)/HER2 and EGFR showed promising results in glioblastoma and renal carcinoma lung metastases, respectively [360,361]. CAR-NK are currently being tested for their safety and efficacy, and the use of modified cytokines in combination with allogeneic NK is currently ongoing (NCT02890758).

\subsection{Stroma-Targeted Therapies}

The stroma is a critical component of a tumor that encompasses the extracellular matrix, recruited mesenchymal stromal cells, fibroblasts, osteoblasts, chondrocytes, macrophages, and myeloid cells, which contributes to cancer progression [362,363]. Anti-FAP antibodies conjugated to drugs induces a cytotoxic effect, which inhibits tumor progression in gastrointestinal cancer [364]. Less specific strategies involve the use of FAP to cleave and activate pro-drug promethelin, as well as the methelin released exerts cytotoxic effect [365]. In addition, the use of both single-agent CAR-T as well as combined agent anti-tumor CAR-T specific for antigen erythropoietin-producing HCC A2 (EphA2) on $\mathrm{FAP}^{+} \mathrm{CAF}$ were reported $[366,367]$. A study showed that the anti-FAP CAR-T and DNA vaccine inhibits tumor growth in a mouse model of GI cancer [368,369]. In addition, a FAP-specific vaccine induces cytotoxic $\mathrm{T}$ cells and also promotes chemotherapy sensitivity $[368,370]$. CAF-derived TGF- $\beta$ plays an inhibitory role on $\mathrm{CD}^{+}$and $\mathrm{CD} 8^{+} \mathrm{T}$ cells $[367,371]$. Therefore, the simultaneous blockade of TGF- $\beta$ and PD-L1 facilitates T cell infiltration into the tumor microenvironment [91]. However, TGF- $\beta$ inhibitors failed to improve the efficacy of anti-PD-1 in tumors [372]. The proliferation of CAF triggered by TGF- $\beta$ inhibition increases matrix metallopeptidase 9 (MMP-9) and reduced the expression of PD-L1. Therefore, a synergetic and sequential approach has been suggested that involves delaying TGF- $\beta$ inhibition until anti-PD 1 resistance is observed [373,374].

Cytokines and chemokines act in a paracrine and autocrine manner within the tumor microenvironment. For instance, IL-8 promotes immunosuppression and tumor escape. In addition, the serum level of IL-8 is associated with a poor prognosis in patients [375]. Furthermore, cytokines are known to have shorter half-lives, and their systemic use is limited due to toxicity $[376,377]$. Of a clinical benefit was the recent advances made towards modification of cytokines by the attachment of polyethylene glycol (PEG) to prolong their shelf lives. Modified cytokines include pegilodecakin (IL-10) (AM0010), biomimetic IL-2 pulmoleukin, IL-2 variant (IL-2v) linked to anti-FAP, and ALT-803; and others are still in development. For example, NKTR-214 (bempegaldesleukin) can target interleukin-2 (IL-2) receptor beta subunit with the potential of turning cold tumors to hot tumors. Most cytokine-based drugs are now given in combination with checkpoint inhibitors, chemotherapy, and CAR-T to enhance their efficacy [378]. Clinical trials testing the efficacy are currently ongoing (NCT03400332) (see Table 3). Similarly, a study showed that inhibition with anti-CXCR2 and anti-PD-1 synergistically inhibits tumor 
formation [379]. Other stroma-targeted strategies include CSF-1R, CXCR1, CXCR2, and CCR2/CCR5 blockades, which inhibit the trafficking and recruitment of myeloid cells such as macrophages into the tumor [380,381]. Surprisingly, CSF-1R inhibitors have failed to improve survival rates in early clinical trials. A recent phase 1 study of emactuzumab alone or in combination with paclitaxel in advanced tumors showed a 7\% ORR without a relevant anti-tumor effect [292]. By contrast, pre-clinical studies showed that CSF-1R inhibition enhances PD-1 in a melanoma mouse model with a BRAF mutation [382].

\section{Conclusions}

GI cancer is a pervasive disease with pathogenic contributions. The tumor immune-microenvironment play a role in the pathogenesis. Mounting evidence that has accumulated from preclinical studies over the years has identified immune therapeutic targets. However, the overall survival advantage of patients treated with immunotherapies in solid tumors including GI cancer is suboptimal. Recent advances in predictive/prognostic biomarkers and combination treatment approaches have been made towards improving patients' responses to immunotherapy. The understanding of the tumor-immune microenvironment and identification of potential predictive biomarkers could hold the answers to future immunotherapy targeting the GI cancers, in particular for the development of precision-based medicine.

Author Contributions: B.A.A. and Y.-H.H. formulated the theme and outline of the review. B.A.A. and R.B.I searched and reviewed literature, drafted and revised the manuscript, and generated the figures and tables. Y.-H.H. reviewed the manuscript, provided revisions, and finalized the manuscript.

Funding: This work was financially supported by research grants from the Ministry of Science and Technology, Taiwan (Grant numbers: MOST 105-2628-B-038-008-MY3, MOST 106-3114-B-038-001, MOST 107-2321-B-038-002, MOST 107-2314-B-038-057, MOST 107-2314-B-038-061, MOST 108-2320-B-038-033-MY3, MOST 108-2321-B-038-003, and MOST 108-2314-B-038-006); Health and Welfare Surcharge of Tobacco Products (Grant numbers: MOHW103-TD-B-111-01, MOHW104-TDU-B-212-124-001, MOHW105-TDU-B-212-134001, MOHW106-TDU-B-212-144001, MOHW107-TDU-B-212-114014, and MOHW108-TDU-B-212-124014); Ministry of Education, Taiwan (Grant numbers: DP2-107-21121-01-T-02 and DP2-108-21121-01-T-02-02);Taipei Medical University (Grant numbers: TMU-T104-06, TMU-T105-06, TMU-T106-03, and 105TMU-CIT-01-3); Taipei Medical University Hospital (Grant numbers: 104TMU-TMUH-04 and 105TMU-TMUH-10); and "TMU Research Center of Cancer Translational Medicine" from The Featured Areas Research Center Program within the framework of the Higher Education Sprout Project by the Ministry of Education (MOE) in Taiwan.

Conflicts of Interest: The authors declare no conflict of interest.

\section{References}

1. Vesely, M.D.; Schreiber, R.D. Cancer Immunoediting: Antigens, Mechanisms, and Implications to Cancer Immunotherapy. Ann. N. Y. Acad. Sci. 2013, 1284, 1-5. [CrossRef] [PubMed]

2. Zumwalt, T.J.; Goel, A. Immunotherapy of Metastatic Colorectal Cancer: Prevailing Challenges and New Perspectives. Curr. Colorectal Cancer Rep. 2015, 11, 125-140. [CrossRef] [PubMed]

3. Han, E.Q.; Li, X.L.; Wang, C.R.; Li, T.F.; Han, S.Y. Chimeric Antigen Receptor-Engineered T Cells for Cancer Immunotherapy: Progress and Challenges. J. Hematol. Oncol. 2013, 6, 47. [CrossRef] [PubMed]

4. Shi, L.; Chen, S.; Yang, L.; Li, Y. The Role of PD-1 and PD-L1 in T-Cell Immune Suppression in Patients with Hematological Malignancies. J. Hematol. Oncol. 2013, 6, 74. [CrossRef] [PubMed]

5. Hazama, S.; Tamada, K.; Yamaguchi, Y.; Kawakami, Y.; Nagano, H. Current Status of Immunotherapy against Gastrointestinal Cancers and Its Biomarkers: Perspective for Precision Immunotherapy. Ann. Gastroenterol. Surg. 2018, 2, 289-303. [CrossRef] [PubMed]

6. Qin, J.; Li, R.; Raes, J.; Arumugam, M.; Burgdorf, K.S.; Manichanh, C.; Nielsen, T.; Pons, N.; Levenez, F.; Yamada, T.; et al. A Human Gut Microbial Gene Catalogue Established by Metagenomic Sequencing. Nature 2010, 464, 59-65. [CrossRef] [PubMed]

7. Tremaroli, V.; Backhed, F. Functional Interactions between the Gut Microbiota and Host Metabolism. Nature 2012, 489, 242-249. [CrossRef] [PubMed] 
8. Pennisi, E. Biomedicine. Cancer Therapies Use a Little Help from Microbial Friends. Science 2013, $342,921$. [CrossRef] [PubMed]

9. Bouskra, D.; Brezillon, C.; Berard, M.; Werts, C.; Varona, R.; Boneca, I.G.; Eberl, G. Lymphoid Tissue Genesis Induced by Commensals through NOD1 Regulates Intestinal Homeostasis. Nature 2008, 456, 507-510. [CrossRef] [PubMed]

10. Diaz Heijtz, R.; Wang, S.; Anuar, F.; Qian, Y.; Bjorkholm, B.; Samuelsson, A.; Hibberd, M.L.; Forssberg, H.; Pettersson, S. Normal Gut Microbiota Modulates Brain Development and Behavior. Proc. Natl. Acad. Sci. USA 2011, 108, 3047-3052. [CrossRef] [PubMed]

11. Smith, C.L.; Dickinson, P.; Forster, T.; Craigon, M.; Ross, A.; Khondoker, M.R.; France, R.; Ivens, A.; Lynn, D.J.; Orme, J.; et al. Identification of a Human Neonatal Immune-Metabolic Network Associated with Bacterial Infection. Nat. Commun. 2014, 5, 4649. [CrossRef] [PubMed]

12. Dominguez-Bello, M.G.; Godoy-Vitorino, F.; Knight, R.; Blaser, M.J. Role of the Microbiome in Human Development. Gut 2019, 68, 1108-1114. [CrossRef] [PubMed]

13. Saus, E.; Iraola-Guzman, S.; Willis, J.R.; Brunet-Vega, A.; Gabaldon, T. Microbiome and Colorectal Cancer: Roles in Carcinogenesis and Clinical Potential. Mol. Aspects Med. 2019. [CrossRef] [PubMed]

14. Weng, M.T.; Chiu, Y.T.; Wei, P.Y.; Chiang, C.W.; Fang, H.L.; Wei, S.C. Microbiota and Gastrointestinal Cancer. J. Formos. Med. Assoc. 2019, 118, S32-S41. [CrossRef] [PubMed]

15. Dickson, I. Microbiome Promotes Pancreatic Cancer. Nat. Rev. Gastroenterol. Hepatol. 2018, 15, 328. [CrossRef] [PubMed]

16. Pushalkar, S.; Hundeyin, M.; Daley, D.; Zambirinis, C.P.; Kurz, E.; Mishra, A.; Mohan, N.; Aykut, B.; Usyk, M.; Torres, L.E.; et al. The Pancreatic Cancer Microbiome Promotes Oncogenesis by Induction of Innate and Adaptive Immune Suppression. Cancer Discov. 2018, 8, 403-416. [CrossRef] [PubMed]

17. Zambirinis, C.P.; Pushalkar, S.; Saxena, D.; Miller, G. Pancreatic Cancer, Inflammation, and Microbiome. Cancer J. 2014, 20, 195-202. [CrossRef]

18. Sun, J.; Furio, L.; Mecheri, R.; van der Does, A.M.; Lundeberg, E.; Saveanu, L.; Chen, Y.; van Endert, P.; Agerberth, B.; Diana, J. Pancreatic Beta-Cells Limit Autoimmune Diabetes via an Immunoregulatory Antimicrobial Peptide Expressed under the Influence of the Gut Microbiota. Immunity 2015, 43, 304-317. [CrossRef]

19. Jenne, C.N.; Kubes, P. Immune Surveillance by the Liver. Nat. Immunol. 2013, 14, 996-1006. [CrossRef]

20. Liu, Y.; Seto, N.L.; Carmona-Rivera, C.; Kaplan, M.J. Accelerated Model of Lupus Autoimmunity and Vasculopathy Driven by Toll-Like Receptor 7/9 Imbalance. Lupus Sci. Med. 2018, 5, e000259. [CrossRef]

21. Huang, L.R.; Wohlleber, D.; Reisinger, F.; Jenne, C.N.; Cheng, R.L.; Abdullah, Z.; Schildberg, F.A.; Odenthal, M.; Dienes, H.P.; van Rooijen, N.; et al. Intrahepatic Myeloid-Cell Aggregates Enable Local Proliferation of CD8(+) T Cells and Successful Immunotherapy against Chronic Viral Liver Infection. Nat. Immunol. 2013, 14, 574-583. [CrossRef] [PubMed]

22. Wu, J.; Meng, Z.; Jiang, M.; Zhang, E.; Trippler, M.; Broering, R.; Bucchi, A.; Krux, F.; Dittmer, U.; Yang, D.; et al. Toll-Like Receptor-Induced Innate Immune Responses in Non-Parenchymal Liver Cells Are Cell Type-Specific. Immunology 2010, 129, 363-374. [CrossRef] [PubMed]

23. Bronte, V.; Wang, M.; Overwijk, W.W.; Surman, D.R.; Pericle, F.; Rosenberg, S.A.; Restifo, N.P. Apoptotic Death of CD8+ T Lymphocytes after Immunization: Induction of a Suppressive Population of Mac-1+/Gr-1+ Cells. J. Immunol. 1998, 161, 5313-5320. [PubMed]

24. Mazzoni, A.; Bronte, V.; Visintin, A.; Spitzer, J.H.; Apolloni, E.; Serafini, P.; Zanovello, P.; Segal, D.M. Myeloid Suppressor Lines Inhibit T Cell Responses by an No-Dependent Mechanism. J. Immunol. 2002, 168, 689-695. [CrossRef] [PubMed]

25. Notas, G.; Kisseleva, T.; Brenner, D. Nk and NKT Cells in Liver Injury and Fibrosis. Clin. Immunol. 2009, 130, 16-26. [CrossRef] [PubMed]

26. Robinson, M.W.; Harmon, C.; O'Farrelly, C. Liver Immunology and Its Role in Inflammation and Homeostasis. Cell Mol. Immunol. 2016, 13, 267-276. [CrossRef] [PubMed]

27. Signoretti, M.; Roggiolani, R.; Stornello, C.; Delle Fave, G.; Capurso, G. Gut Microbiota and Pancreatic Diseases. Minerva Gastroenterol Dietol. 2017, 63, 399-410.

28. Dejea, C.M.; Fathi, P.; Craig, J.M.; Boleij, A.; Taddese, R.; Geis, A.L.; Wu, X.; DeStefano Shields, C.E.; Hechenbleikner, E.M.; Huso, D.L.; et al. Patients with Familial Adenomatous Polyposis Harbor Colonic Biofilms Containing Tumorigenic Bacteria. Science 2018, 359, 592-597. [CrossRef] 
29. Fan, X.; Alekseyenko, A.V.; Wu, J.; Peters, B.A.; Jacobs, E.J.; Gapstur, S.M.; Purdue, M.P.; Abnet, C.C.; Stolzenberg-Solomon, R.; Miller, G.; et al. Human Oral Microbiome and Prospective Risk for Pancreatic Cancer: A Population-Based Nested Case-Control Study. Gut 2018, 67, 120-127. [CrossRef]

30. Olsen, I.; Yamazaki, K. Can Oral Bacteria Affect the Microbiome of the Gut? J. Oral. Microbiol. 2019, 11, 1586422. [CrossRef]

31. Shaik-Dasthagirisaheb, Y.B.; Huang, N.; Weinberg, E.O.; Shen, S.S.; Genco, C.A.; Gibson, F.C., 3rd. Aging and Contribution of MYD88 and TRIF to Expression of TLR Pathway-Associated Genes Following Stimulation with Porphyromonas Gingivalis. J. Periodontal Res. 2015, 50, 89-102. [CrossRef] [PubMed]

32. Dong, H.; Strome, S.E.; Salomao, D.R.; Tamura, H.; Hirano, F.; Flies, D.B.; Roche, P.C.; Lu, J.; Zhu, G.; Tamada, K.; et al. Tumor-Associated B7-H1 Promotes T-Cell Apoptosis: A Potential Mechanism of Immune Evasion. Nat. Med. 2002, 8, 793-800. [CrossRef]

33. Nielsen, S.R.; Quaranta, V.; Linford, A.; Emeagi, P.; Rainer, C.; Santos, A.; Ireland, L.; Sakai, T.; Sakai, K.; Kim, Y.S.; et al. Macrophage-Secreted Granulin Supports Pancreatic Cancer Metastasis by Inducing Liver Fibrosis. Nat. Cell Biol. 2016, 18, 549-560. [CrossRef]

34. Wang, L.; Zhu, R.; Huang, Z.; Li, H.; Zhu, H. Lipopolysaccharide-Induced Toll-Like Receptor 4 Signaling in Cancer Cells Promotes Cell Survival and Proliferation in Hepatocellular Carcinoma. Dig. Dis. Sci. 2013, 58, 2223-2236. [CrossRef] [PubMed]

35. Akira, S.; Takeda, K. Toll-Like Receptor Signalling. Nat. Rev. Immunol. 2004, 4, 499-511. [CrossRef]

36. Naugler, W.E.; Sakurai, T.; Kim, S.; Maeda, S.; Kim, K.; Elsharkawy, A.M.; Karin, M. Gender Disparity in Liver Cancer Due to Sex Differences in MYD88-Dependent IL-6 Production. Science 2007, 317, 121-124. [CrossRef]

37. Gagniere, J.; Raisch, J.; Veziant, J.; Barnich, N.; Bonnet, R.; Buc, E.; Bringer, M.A.; Pezet, D.; Bonnet, M. Gut Microbiota Imbalance and Colorectal Cancer. World J. Gastroenterol 2016, 22, 501-518. [CrossRef] [PubMed]

38. Baxter, N.T.; Zackular, J.P.; Chen, G.Y.; Schloss, P.D. Structure of the Gut Microbiome Following Colonization with Human Feces Determines Colonic Tumor Burden. Microbiome 2014, 2, 20. [CrossRef]

39. Kostic, A.D.; Chun, E.; Robertson, L.; Glickman, J.N.; Gallini, C.A.; Michaud, M.; Clancy, T.E.; Chung, D.C.; Lochhead, P.; Hold, G.L.; et al. Fusobacterium Nucleatum Potentiates Intestinal Tumorigenesis and Modulates the Tumor-Immune Microenvironment. Cell Host Microbe 2013, 14, 207-215. [CrossRef]

40. Ryz, N.R.; Patterson, S.J.; Zhang, Y.; Ma, C.; Huang, T.; Bhinder, G.; Wu, X.; Chan, J.; Glesby, A.; Sham, H.P.; et al. Active Vitamin D (1,25-Dihydroxyvitamin D3) Increases Host Susceptibility to Citrobacter Rodentium by Suppressing Mucosal Th17 Responses. Am. J. Physiol. Gastrointest Liver Physiol. 2012, 303, G1299-G1311. [CrossRef]

41. Loddo, I.; Romano, C. Inflammatory Bowel Disease: Genetics, Epigenetics, and Pathogenesis. Front. Immunol. 2015, 6, 551. [CrossRef] [PubMed]

42. Wu, S.; Rhee, K.J.; Albesiano, E.; Rabizadeh, S.; Wu, X.; Yen, H.R.; Huso, D.L.; Brancati, F.L.; Wick, E.; McAllister, F.; et al. A Human Colonic Commensal Promotes Colon Tumorigenesis Via Activation of T Helper Type 17 T Cell Responses. Nat. Med. 2009, 15, 1016-1022. [CrossRef] [PubMed]

43. Lee, S.H.; Hu, L.L.; Gonzalez-Navajas, J.; Seo, G.S.; Shen, C.; Brick, J.; Herdman, S.; Varki, N.; Corr, M.; Lee, J.; et al. ERK Activation Drives Intestinal Tumorigenesis in APC(Min/+) Mice. Nat. Med. 2010, 16, 665-670. [CrossRef] [PubMed]

44. Dejea, C.M.; Wick, E.C.; Hechenbleikner, E.M.; White, J.R.; Mark Welch, J.L.; Rossetti, B.J.; Peterson, S.N.; Snesrud, E.C.; Borisy, G.G.; Lazarev, M.; et al. Microbiota Organization Is a Distinct Feature of Proximal Colorectal Cancers. Proc. Natl. Acad. Sci. USA 2014, 111, 18321-18326. [CrossRef] [PubMed]

45. Hold, G.L.; Allen-Vercoe, E. Gut Microbial Biofilm Composition and Organisation Holds the Key to CRC. Nat. Rev. Gastroenterol Hepatol. 2019, 16, 329-330. [CrossRef] [PubMed]

46. Tomkovich, S.; Dejea, C.M.; Winglee, K.; Drewes, J.L.; Chung, L.; Housseau, F.; Pope, J.L.; Gauthier, J.; Sun, X.; Muhlbauer, M.; et al. Human Colon Mucosal Biofilms from Healthy or Colon Cancer Hosts Are Carcinogenic. J. Clin. Invest. 2019, 130, 1699-1712. [CrossRef]

47. Liao, R.; Sun, J.; Wu, H.; Yi, Y.; Wang, J.X.; He, H.W.; Cai, X.Y.; Zhou, J.; Cheng, Y.F.; Fan, J.; et al. High Expression of IL-17 and IL-17RE Associate with Poor Prognosis of Hepatocellular Carcinoma. J. Exp. Clin. Cancer Res. 2013, 32, 3. [CrossRef]

48. Oh, J.K.; Weiderpass, E. Infection and Cancer: Global Distribution and Burden of Diseases. Ann. Glob Health 2014, 80, 384-392. [CrossRef] 
49. Liu, C.J.; Chu, Y.T.; Shau, W.Y.; Kuo, R.N.; Chen, P.J.; Lai, M.S. Treatment of Patients with Dual Hepatitis C and B by Peginterferon Alpha and Ribavirin Reduced Risk of Hepatocellular Carcinoma and Mortality. Gut 2014, 63, 506-514. [CrossRef]

50. Fiorino, S.; Lorenzini, S.; Masetti, M.; Deleonardi, G.; Grondona, A.G.; Silvestri, T.; Chili, E.; Del Prete, P.; Bacchi-Reggiani, L.; Cuppini, A.; et al. Hepatitis B and C Virus Infections as Possible Risk Factor for Pancreatic Adenocarcinoma. Med. Hypotheses 2012, 79, 678-697. [CrossRef]

51. Tomasiewicz, K.; Modrzewska, R.; Lyczak, A.; Krawczuk, G. TT Virus Infection and Pancreatic Cancer: Relationship or Accidental Coexistence. World J. Gastroenterol 2005, 11, 2847-2849. [CrossRef] [PubMed]

52. Pelizzer, T.; Dias, C.P.; Poeta, J.; Torriani, T.; Roncada, C. Colorectal Cancer Prevalence Linked to Human Papillomavirus: A Systematic Review with Meta-Analysis. Rev. Bras. Epidemiol. 2016, 19, 791-802. [CrossRef] [PubMed]

53. Jarzynski, A.; Zajac, P.; Zebrowski, R.; Boguszewska, A.; Polz-Dacewicz, M. Occurrence of Bk Virus and Human Papilloma Virus in Colorectal Cancer. Ann. Agric. Environ. Med. 2017, 24, 440-445. [CrossRef] [PubMed]

54. Mjelle, R.; Sjursen, W.; Thommesen, L.; Saetrom, P.; Hofsli, E. Small Rna Expression from Viruses, Bacteria and Human Mirnas in Colon Cancer Tissue and Its Association with Microsatellite Instability and Tumor Location. BMC Cancer 2019, 19, 161. [CrossRef] [PubMed]

55. Mantovani, A.; Allavena, P.; Sica, A.; Balkwill, F. Cancer-Related Inflammation. Nature 2008, 454, $436-444$. [CrossRef] [PubMed]

56. Zur Hausen, H. The Search for Infectious Causes of Human Cancers: Where and Why. Virology 2009, 392, 1-10. [CrossRef] [PubMed]

57. Szabo, G.; Petrasek, J. Inflammasome Activation and Function in Liver Disease. Nat. Rev. Gastroenterol Hepatol. 2015, 12, 387-400. [CrossRef] [PubMed]

58. Fan, Y.; Mao, R.; Yang, J. NF-Kappab and Stat3 Signaling Pathways Collaboratively Link Inflammation to Cancer. Protein Cell 2013, 4, 176-185. [CrossRef]

59. Naugler, W.E.; Karin, M. NF-Kappab and Cancer-Identifying Targets and Mechanisms. Curr. Opin. Genet. Dev. 2008, 18, 19-26. [CrossRef]

60. Wu, W.K.; Sung, J.J.; Lee, C.W.; Yu, J.; Cho, C.H. Cyclooxygenase-2 in Tumorigenesis of Gastrointestinal Cancers: An Update on the Molecular Mechanisms. Cancer Lett. 2010, 295, 7-16. [CrossRef]

61. He, G.; Yu, G.Y.; Temkin, V.; Ogata, H.; Kuntzen, C.; Sakurai, T.; Sieghart, W.; Peck-Radosavljevic, M.; Leffert, H.L.; Karin, M. Hepatocyte Ikkbeta/NF-Kappab Inhibits Tumor Promotion and Progression by Preventing Oxidative Stress-Driven Stat3 Activation. Cancer Cell 2010, 17, 286-297. [CrossRef] [PubMed]

62. Greten, F.R.; Weber, C.K.; Greten, T.F.; Schneider, G.; Wagner, M.; Adler, G.; Schmid, R.M. Stat3 and Nf-Kappab Activation Prevents Apoptosis in Pancreatic Carcinogenesis. Gastroenterology 2002, 123, 2052-2063. [CrossRef] [PubMed]

63. Chung, S.S.; Wu, Y.; Okobi, Q.; Adekoya, D.; Atefi, M.; Clarke, O.; Dutta, P.; Vadgama, J.V. Proinflammatory Cytokines IL-6 and TNF-Alpha Increased Telomerase Activity through NF-Kappa-b/STAT1/STAT3 Activation, and Withaferin a Inhibited the Signaling in Colorectal Cancer Cells. Mediators Inflamm. 2017, 2017, 5958429. [CrossRef] [PubMed]

64. Sunami, Y.; Ringelhan, M.; Kokai, E.; Lu, M.; O'Connor, T.; Lorentzen, A.; Weber, A.; Rodewald, A.K.; Mullhaupt, B.; Terracciano, L.; et al. Canonical NF-Kappa-b Signaling in Hepatocytes Acts as a Tumor-Suppressor in Hepatitis B Virus Surface Antigen-Driven Hepatocellular Carcinoma by Controlling the Unfolded Protein Response. Hepatology 2016, 63, 1592-1607. [CrossRef] [PubMed]

65. Knolle, P.A.; Thimme, R. Hepatic Immune Regulation and Its Involvement in Viral Hepatitis Infection. Gastroenterology 2014, 146, 1193-1207. [CrossRef]

66. Larrubia, J.R.; Lokhande, M.U.; Garcia-Garzon, S.; Miquel, J.; Gonzalez-Praetorius, A.; Parra-Cid, T.; Sanz-de-Villalobos, E. Persistent Hepatitis C Virus (Hcv) Infection Impairs HCV-Specific Cytotoxic T Cell Reactivity through Mcl-1/Bim Imbalance Due to CD127 Down-Regulation. J. Viral Hepat. 2013, 20, 85-94. [CrossRef] [PubMed]

67. Wieland, D.; Kemming, J.; Schuch, A.; Emmerich, F.; Knolle, P.; Neumann-Haefelin, C.; Held, W.; Zehn, D.; Hofmann, M.; Thimme, R. Tcf1(+) Hepatitis C Virus-Specific CD8(+) T Cells Are Maintained after Cessation of Chronic Antigen Stimulation. Nat. Commun. 2017, 8, 15050. [CrossRef] [PubMed] 
68. Barber, D.L.; Wherry, E.J.; Masopust, D.; Zhu, B.; Allison, J.P.; Sharpe, A.H.; Freeman, G.J.; Ahmed, R. Restoring Function in Exhausted CD8 T Cells During Chronic Viral Infection. Nature 2006, 439, 682-687. [CrossRef]

69. Khan, O.; Giles, J.R.; McDonald, S.; Manne, S.; Ngiow, S.F.; Patel, K.P.; Werner, M.T.; Huang, A.C.; Alexander, K.A.; Wu, J.E.; et al. Tox Transcriptionally and Epigenetically Programs CD8(+) T Cell Exhaustion. Nature 2019, 571, 211-218. [CrossRef]

70. Schietinger, A.; Philip, M.; Krisnawan, V.E.; Chiu, E.Y.; Delrow, J.J.; Basom, R.S.; Lauer, P.; Brockstedt, D.G.; Knoblaugh, S.E.; Hammerling, G.J.; et al. Tumor-Specific T Cell Dysfunction Is a Dynamic Antigen-Driven Differentiation Program Initiated Early During Tumorigenesis. Immunity 2016, 45, 389-401. [CrossRef]

71. Miller, B.C.; Sen, D.R.; Al Abosy, R.; Bi, K.; Virkud, Y.V.; LaFleur, M.W.; Yates, K.B.; Lako, A.; Felt, K.; Naik, G.S.; et al. Subsets of Exhausted CD8(+) T Cells Differentially Mediate Tumor Control and Respond to Checkpoint Blockade. Nat. Immunol. 2019, 20, 326-336. [CrossRef] [PubMed]

72. Wang, Y.G.; Zheng, D.H.; Shi, M.; Xu, X.M. T Cell Dysfunction in Chronic Hepatitis B Infection and Liver Cancer: Evidence from Transcriptome Analysis. J. Med. Genet. 2019, 56, 22-28. [CrossRef] [PubMed]

73. Paley, M.A.; Kroy, D.C.; Odorizzi, P.M.; Johnnidis, J.B.; Dolfi, D.V.; Barnett, B.E.; Bikoff, E.K.; Robertson, E.J.; Lauer, G.M.; Reiner, S.L.; et al. Progenitor and Terminal Subsets of CD8+ T Cells Cooperate to Contain Chronic Viral Infection. Science 2012, 338, 1220-1225. [CrossRef] [PubMed]

74. Horton, B.L.; Williams, J.B.; Cabanov, A.; Spranger, S.; Gajewski, T.F. Intratumoral CD8(+) T-Cell Apoptosis Is a Major Component of T-Cell Dysfunction and Impedes Antitumor Immunity. Cancer Immunol. Res. 2018, 6, 14-24. [CrossRef] [PubMed]

75. Kalluri, R. The Biology and Function of Fibroblasts in Cancer. Nat. Rev. Cancer 2016, 16, 582-598. [CrossRef]

76. Orimo, A.; Gupta, P.B.; Sgroi, D.C.; Arenzana-Seisdedos, F.; Delaunay, T.; Naeem, R.; Carey, V.J.; Richardson, A.L.; Weinberg, R.A. Stromal Fibroblasts Present in Invasive Human Breast Carcinomas Promote Tumor Growth and Angiogenesis through Elevated SDF-1/CXCL12 Secretion. Cell 2005, 121, 335-348. [CrossRef] [PubMed]

77. Quante, M.; Tu, S.P.; Tomita, H.; Gonda, T.; Wang, S.S.; Takashi, S.; Baik, G.H.; Shibata, W.; Diprete, B.; Betz, K.S.; et al. Bone Marrow-Derived Myofibroblasts Contribute to the Mesenchymal Stem Cell Niche and Promote Tumor Growth. Cancer Cell 2011, 19, 257-272. [CrossRef]

78. Li, Y.; Wang, J.; Asahina, K. Mesothelial Cells Give Rise to Hepatic Stellate Cells and Myofibroblasts via Mesothelial-Mesenchymal Transition in Liver Injury. Proc. Natl. Acad. Sci. USA 2013, 110, 2324-2329. [CrossRef]

79. Su, S.; Chen, J.; Yao, H.; Liu, J.; Yu, S.; Lao, L.; Wang, M.; Luo, M.; Xing, Y.; Chen, F.; et al. CD10(+)GPR77(+) Cancer-Associated Fibroblasts Promote Cancer Formation and Chemoresistance by Sustaining Cancer Stemness. Cell 2018, 172, 841-856. [CrossRef]

80. Ozdemir, B.C.; Pentcheva-Hoang, T.; Carstens, J.L.; Zheng, X.; Wu, C.C.; Simpson, T.R.; Laklai, H.; Sugimoto, H.; Kahlert, C.; Novitskiy, S.V.; et al. Depletion of Carcinoma-Associated Fibroblasts and Fibrosis Induces Immunosuppression and Accelerates Pancreas Cancer with Reduced Survival. Cancer Cell 2014, 25, 719-734. [CrossRef]

81. Lo, A.; Li, C.P.; Buza, E.L.; Blomberg, R.; Govindaraju, P.; Avery, D.; Monslow, J.; Hsiao, M.; Pure, E. Fibroblast Activation Protein Augments Progression and Metastasis of Pancreatic Ductal Adenocarcinoma. JCI Insight 2017, 2. [CrossRef] [PubMed]

82. Santos, A.M.; Jung, J.; Aziz, N.; Kissil, J.L.; Pure, E. Targeting Fibroblast Activation Protein Inhibits Tumor Stromagenesis and Growth in Mice. J. Clin. Invest. 2009, 119, 3613-3625. [CrossRef] [PubMed]

83. Calon, A.; Lonardo, E.; Berenguer-Llergo, A.; Espinet, E.; Hernando-Momblona, X.; Iglesias, M.; Sevillano, M.; Palomo-Ponce, S.; Tauriello, D.V.; Byrom, D.; et al. Stromal Gene Expression Defines Poor-Prognosis Subtypes in Colorectal Cancer. Nat. Genet. 2015, 47, 320-329. [CrossRef] [PubMed]

84. Catenacci, D.V.; Junttila, M.R.; Karrison, T.; Bahary, N.; Horiba, M.N.; Nattam, S.R.; Marsh, R.; Wallace, J.; Kozloff, M.; Rajdev, L.; et al. Randomized Phase Ib/II Study of Gemcitabine Plus Placebo or Vismodegib, a Hedgehog Pathway Inhibitor, in Patients with Metastatic Pancreatic Cancer. J. Clin. Oncol. 2015, 33, 4284-4292. [CrossRef] [PubMed]

85. Lee, J.J.; Perera, R.M.; Wang, H.; Wu, D.C.; Liu, X.S.; Han, S.; Fitamant, J.; Jones, P.D.; Ghanta, K.S.; Kawano, S.; et al. Stromal Response to Hedgehog Signaling Restrains Pancreatic Cancer Progression. Proc. Natl. Acad. Sci. USA 2014, 111, E3091-E3100. [CrossRef] [PubMed] 
86. Yang, X.; Lin, Y.; Shi, Y.; Li, B.; Liu, W.; Yin, W.; Dang, Y.; Chu, Y.; Fan, J.; He, R. FAP Promotes Immunosuppression by Cancer-Associated Fibroblasts in the Tumor Microenvironment Via STAT3-CCL2 Signaling. Cancer Res. 2016, 76, 4124-4135. [CrossRef]

87. Feig, C.; Jones, J.O.; Kraman, M.; Wells, R.J.; Deonarine, A.; Chan, D.S.; Connell, C.M.; Roberts, E.W.; Zhao, Q.; Caballero, O.L.; et al. Targeting CXCL12 from Fap-Expressing Carcinoma-Associated Fibroblasts Synergizes with Anti-PD-L1 Immunotherapy in Pancreatic Cancer. Proc. Natl. Acad. Sci. USA 2013, 110, 20212-20217. [CrossRef]

88. Jiang, L.; Li, X.; Zhang, Y.; Zhang, M.; Tang, Z.; Lv, K. Microarray and Bioinformatics Analyses of Gene Expression Profiles in Balb/C Murine Macrophage Polarization. Mol. Med. Rep. 2017, 16, 7382-7390. [CrossRef]

89. Kumar, V.; Donthireddy, L.; Marvel, D.; Condamine, T.; Wang, F.; Lavilla-Alonso, S.; Hashimoto, A.; Vonteddu, P.; Behera, R.; Goins, M.A.; et al. Cancer-Associated Fibroblasts Neutralize the Anti-Tumor Effect of CSF1 Receptor Blockade by Inducing PMN-MDSC Infiltration of Tumors. Cancer Cell 2017, 32, 654-668. [CrossRef]

90. De Monte, L.; Reni, M.; Tassi, E.; Clavenna, D.; Papa, I.; Recalde, H.; Braga, M.; Di Carlo, V.; Doglioni, C.; Protti, M.P. Intratumor T Helper Type 2 Cell Infiltrate Correlates with Cancer-Associated Fibroblast Thymic Stromal Lymphopoietin Production and Reduced Survival in Pancreatic Cancer. J. Exp. Med. 2011, 208, 469-478. [CrossRef]

91. Tauriello, D.V.F.; Palomo-Ponce, S.; Stork, D.; Berenguer-Llergo, A.; Badia-Ramentol, J.; Iglesias, M.; Sevillano, M.; Ibiza, S.; Canellas, A.; Hernando-Momblona, X.; et al. TGF-beta Drives Immune Evasion in Genetically Reconstituted Colon Cancer Metastasis. Nature 2018, 554, 538-543. [CrossRef] [PubMed]

92. Li, Y.; Wang, R.; Xiong, S.; Wang, X.; Zhao, Z.; Bai, S.; Wang, Y.; Zhao, Y.; Cheng, B. Cancer-Associated Fibroblasts Promote the Stemness of CD24(+) Liver Cells via Paracrine Signaling. J. Mol. Med. (Berl) 2019, 97, 243-255. [CrossRef] [PubMed]

93. Cannarile, M.A.; Weisser, M.; Jacob, W.; Jegg, A.M.; Ries, C.H.; Ruttinger, D. Colony-Stimulating Factor 1 Receptor (CSF1R) Inhibitors in Cancer Therapy. J. Immunother. Cancer 2017, 5, 53. [CrossRef] [PubMed]

94. Beswick, E.J.; Grim, C.; Singh, A.; Aguirre, J.E.; Tafoya, M.; Qiu, S.; Rogler, G.; McKee, R.; Samedi, V.; Ma, T.Y.; et al. Expression of Programmed Death-Ligand 1 by Human Colonic CD90(+) Stromal Cells Differs between Ulcerative Colitis and Crohn's Disease and Determines Their Capacity to Suppress Th1 Cells. Front. Immunol. 2018, 9. [CrossRef] [PubMed]

95. Turley, S.J.; Cremasco, V.; Astarita, J.L. Immunological Hallmarks of Stromal Cells in the Tumour Microenvironment. Nat. Rev. Immunol. 2015, 15, 669-682. [CrossRef] [PubMed]

96. Cheng, Y.; Li, H.; Deng, Y.; Tai, Y.; Zeng, K.; Zhang, Y.; Liu, W.; Zhang, Q.; Yang, Y. Cancer-Associated Fibroblasts Induce Pdl1 + Neutrophils through the IL6-STAT3 Pathway That Foster Immune Suppression in Hepatocellular Carcinoma. Cell Death Dis. 2018, 9, 422. [CrossRef] [PubMed]

97. Menard, C.; Blay, J.Y.; Borg, C.; Michiels, S.; Ghiringhelli, F.; Robert, C.; Nonn, C.; Chaput, N.; Taieb, J.; Delahaye, N.F.; et al. Natural Killer Cell IFN-Gamma Levels Predict Long-Term Survival with Imatinib Mesylate Therapy in Gastrointestinal Stromal Tumor-Bearing Patients. Cancer Res. 2009, 69, 3563-3569. [CrossRef] [PubMed]

98. Angka, L.; Martel, A.B.; Kilgour, M.; Jeong, A.; Sadiq, M.; de Souza, C.T.; Baker, L.; Kennedy, M.A.; Kekre, N.; Auer, R.C. Natural Killer Cell IFN-gamma Secretion Is Profoundly Suppressed Following Colorectal Cancer Surgery. Ann. Surg. Oncol. 2018, 25, 3747-3754. [CrossRef]

99. Cooper, M.A.; Fehniger, T.A.; Turner, S.C.; Chen, K.S.; Ghaheri, B.A.; Ghayur, T.; Carson, W.E.; Caligiuri, M.A. Human Natural Killer Cells: A Unique Innate Immunoregulatory Role for the CD56(Bright) Subset. Blood 2001, 97, 3146-3151. [CrossRef]

100. Wang, W.; Erbe, A.K.; Hank, J.A.; Morris, Z.S.; Sondel, P.M. NK Cell-Mediated Antibody-Dependent Cellular Cytotoxicity in Cancer Immunotherapy. Front. Immunol. 2015, 6, 368. [CrossRef]

101. Easom, N.J.W.; Stegmann, K.A.; Swadling, L.; Pallett, L.J.; Burton, A.R.; Odera, D.; Schmidt, N.; Huang, W.C.; Fusai, G.; Davidson, B.; et al. IL-15 Overcomes Hepatocellular Carcinoma-Induced NK Cell Dysfunction. Front. Immunol. 2018, 9, 1009. [CrossRef] [PubMed]

102. Sun, C.; Xu, J.; Huang, Q.; Huang, M.; Wen, H.; Zhang, C.; Wang, J.; Song, J.; Zheng, M.; Sun, H.; et al. High NKG2A Expression Contributes to NK Cell Exhaustion and Predicts a Poor Prognosis of Patients with Liver Cancer. Oncoimmunology 2017, 6, e1264562. [CrossRef] [PubMed] 
103. Cai, L.; Zhang, Z.; Zhou, L.; Wang, H.; Fu, J.; Zhang, S.; Shi, M.; Zhang, H.; Yang, Y.; Wu, H.; et al. Functional Impairment in Circulating and Intrahepatic NK Cells and Relative Mechanism in Hepatocellular Carcinoma Patients. Clin. Immunol. 2008, 129, 428-437. [CrossRef] [PubMed]

104. Sui, Q.; Zhang, J.; Sun, X.; Zhang, C.; Han, Q.; Tian, Z. Nk Cells Are the Crucial Antitumor Mediators When STAT3-Mediated Immunosuppression Is Blocked in Hepatocellular Carcinoma. J. Immunol. 2014, 193, 2016-2023. [CrossRef] [PubMed]

105. Bang, S.; Kim, H.S.; Choo, Y.S.; Park, S.W.; Chung, J.B.; Song, S.Y. Differences in Immune Cells Engaged in Cell-Mediated Immunity after Chemotherapy for Far Advanced Pancreatic Cancer. Pancreas 2006, 32, $29-36$. [CrossRef]

106. Jobin, G.; Rodriguez-Suarez, R.; Betito, K. Association between Natural Killer Cell Activity and Colorectal Cancer in High-Risk Subjects Undergoing Colonoscopy. Gastroenterology 2017, 153, 980-987. [CrossRef] [PubMed]

107. Wirsdorfer, F.; Bangen, J.M.; Pastille, E.; Hansen, W.; Flohe, S.B. Breaking the Co-Operation between Bystander T-Cells and Natural Killer Cells Prevents the Development of Immunosuppression after Traumatic Skeletal Muscle Injury in Mice. Clin. Sci. (Lond.) 2015, 128, 825-838. [CrossRef]

108. Duan, X.; Deng, L.; Chen, X.; Lu, Y.; Zhang, Q.; Zhang, K.; Hu, Y.; Zeng, J.; Sun, W. Clinical Significance of the Immunostimulatory MHC Class I Chain-Related Molecule a and NKG2D Receptor on NK Cells in Pancreatic Cancer. Med. Oncol. 2011, 28, 466-474. [CrossRef]

109. Jun, E.; Song, A.Y.; Choi, J.W.; Lee, H.H.; Kim, M.Y.; Ko, D.H.; Kang, H.J.; Kim, S.W.; Bryceson, Y.; Kim, S.C.; et al. Progressive Impairment of Nk Cell Cytotoxic Degranulation Is Associated with TGF-Beta1 Deregulation and Disease Progression in Pancreatic Cancer. Front. Immunol. 2019, 10, 1354. [CrossRef]

110. Wang, S.; Hong, S.; Wezeman, M.; Qian, J.; Yang, J.; Yi, Q. Dendritic Cell Vaccine but Not Idiotype-KLH Protein Vaccine Primes Therapeutic Tumor-Specific Immunity against Multiple Myeloma. Front. Biosci. 2007, 12, 3566-3575. [CrossRef]

111. Liu, N.; Jiang, Y.; Chen, J.; Nan, H.; Zhao, Y.; Chu, X.; Wang, A.; Wang, D.; Qin, T.; Gao, S.; et al. IL-33 Drives the Antitumor Effects of Dendritic Cells Via the Induction of Tc9 Cells. Cell Mol. Immunol. 2019, 16, 644-651. [CrossRef] [PubMed]

112. Ouyang, F.Z.; Wu, R.Q.; Wei, Y.; Liu, R.X.; Yang, D.; Xiao, X.; Zheng, L.; Li, B.; Lao, X.M.; Kuang, D.M. Dendritic Cell-Elicited B-Cell Activation Fosters Immune Privilege via IL-10 Signals in Hepatocellular Carcinoma. Nat. Commun. 2016, 7, 13453. [CrossRef] [PubMed]

113. Yuan, A.; Steigen, S.E.; Goll, R.; Vonen, B.; Husbekk, A.; Cui, G.; Florholmen, J. Dendritic Cell Infiltration Pattern Along the Colorectal Adenoma-Carcinoma Sequence. APMIS 2008, 116, 445-456. [CrossRef]

114. Pryczynicz, A.; Cepowicz, D.; Zareba, K.; Gryko, M.; Holody-Zareba, J.; Kedra, B.; Kemona, A.; Guzinska-Ustymowicz, K. Dysfunctions in the Mature Dendritic Cells Are Associated with the Presence of Metastases of Colorectal Cancer in the Surrounding Lymph Nodes. Gastroenterol Res. Pract. 2016, 2016, 2405437. [CrossRef] [PubMed]

115. Sung, G.H.; Chang, H.; Lee, J.Y.; Song, S.Y.; Kim, H.S. Pancreatic-Cancer-Cell-Derived Trefoil Factor 2 Impairs Maturation and Migration of Human Monocyte-Derived Dendritic Cells in Vitro. Anim. Cells Syst. (Seoul) 2018, 22, 368-381. [CrossRef] [PubMed]

116. Barilla, R.M.; Diskin, B.; Caso, R.C.; Lee, K.B.; Mohan, N.; Buttar, C.; Adam, S.; Sekendiz, Z.; Wang, J.; Salas, R.D.; et al. Specialized Dendritic Cells Induce Tumor-Promoting IL-10(+)IL-17(+) Foxp3(Neg) Regulatory CD4(+) T Cells in Pancreatic Carcinoma. Nat. Commun. 2019, 10, 1424. [CrossRef] [PubMed]

117. Chihara, N.; Madi, A.; Karwacz, K.; Awasthi, A.; Kuchroo, V.K. Differentiation and Characterization of Tr1 Cells. Curr. Protoc. Immunol. 2016, 113, 3-27.

118. Yao, Y.; Vent-Schmidt, J.; McGeough, M.D.; Wong, M.; Hoffman, H.M.; Steiner, T.S.; Levings, M.K. Tr1 Cells, but Not Foxp3+ Regulatory T Cells, Suppress NLRP3 Inflammasome Activation via an IL-10-Dependent Mechanism. J. Immunol. 2015, 195, 488-497. [CrossRef]

119. Hu, Z.; Ma, Y.; Shang, Z.; Hu, S.; Liang, K.; Liang, W.; Xing, X.; Wang, Y.; Du, X. Improving Immunotherapy for Colorectal Cancer Using Dendritic Cells Combined with Anti-Programmed Death-Ligand in Vitro. Oncol. Lett. 2018, 15, 5345-5351. [CrossRef]

120. Yang, L.; Zhang, Y. Tumor-Associated Macrophages, Potential Targets for Cancer Treatment. Biomark Res. 2017, 5, 25. [CrossRef] 
121. Mantovani, A.; Sica, A. Macrophages, Innate Immunity and Cancer: Balance, Tolerance, and Diversity. Curr. Opin. Immunol. 2010, 22, 231-237. [CrossRef] [PubMed]

122. Fu, X.T.; Song, K.; Zhou, J.; Shi, Y.H.; Liu, W.R.; Shi, G.M.; Gao, Q.; Wang, X.Y.; Ding, Z.B.; Fan, J. Tumor-Associated Macrophages Modulate Resistance to Oxaliplatin Via Inducing Autophagy in Hepatocellular Carcinoma. Cancer Cell Int. 2019, 19, 71. [CrossRef] [PubMed]

123. Waniczek, D.; Lorenc, Z.; Snietura, M.; Wesecki, M.; Kopec, A.; Muc-Wierzgon, M. Tumor-Associated Macrophages and Regulatory T Cells Infiltration and the Clinical Outcome in Colorectal Cancer. Arch. Immunol. Ther. Exp. (Warsz) 2017, 65, 445-454. [CrossRef] [PubMed]

124. Cui, Y.L.; Li, H.K.; Zhou, H.Y.; Zhang, T.; Li, Q. Correlations of Tumor-Associated Macrophage Subtypes with Liver Metastases of Colorectal Cancer. Asian Pac. J. Cancer Prev. 2013, 14, 1003-1007. [CrossRef] [PubMed]

125. Yoshikawa, K.; Mitsunaga, S.; Kinoshita, T.; Konishi, M.; Takahashi, S.; Gotohda, N.; Kato, Y.; Aizawa, M.; Ochiai, A. Impact of Tumor-Associated Macrophages on Invasive Ductal Carcinoma of the Pancreas Head. Cancer Sci. 2012, 103, 2012-2020. [CrossRef] [PubMed]

126. Zhang, Q.B.; Jia, Q.A.; Wang, H.; Hu, C.X.; Sun, D.; Jiang, R.D.; Zhang, Z.L. High-Mobility Group Protein Box1 Expression Correlates with Peritumoral Macrophage Infiltration and Unfavorable Prognosis in Patients with Hepatocellular Carcinoma and Cirrhosis. BMC Cancer 2016, 16, 880. [CrossRef] [PubMed]

127. Movahedi, K.; Van Ginderachter, J.A. The Ontogeny and Microenvironmental Regulation of Tumor-Associated Macrophages. Antioxid. Redox Signal. 2016, 25, 775-791. [CrossRef]

128. Sanford, D.E.; Belt, B.A.; Panni, R.Z.; Mayer, A.; Deshpande, A.D.; Carpenter, D.; Mitchem, J.B.; Plambeck-Suess, S.M.; Worley, L.A.; Goetz, B.D.; et al. Inflammatory Monocyte Mobilization Decreases Patient Survival in Pancreatic Cancer: A Role for Targeting the CCL2/CCR2 Axis. Clin. Cancer Res. 2013, 19, 3404-3415. [CrossRef]

129. Bartneck, M.; Schrammen, P.L.; Mockel, D.; Govaere, O.; Liepelt, A.; Krenkel, O.; Ergen, C.; McCain, M.V.; Eulberg, D.; Luedde, T.; et al. The CCR2(+) Macrophage Subset Promotes Pathogenic Angiogenesis for Tumor Vascularization in Fibrotic Livers. Cell Mol. Gastroenterol Hepatol. 2019, 7, 371-390. [CrossRef]

130. Wei, S.; Nandi, S.; Chitu, V.; Yeung, Y.G.; Yu, W.; Huang, M.; Williams, L.T.; Lin, H.; Stanley, E.R. Functional Overlap but Differential Expression of CSF-1 and IL-34 in Their CSF-1 Receptor-Mediated Regulation of Myeloid Cells. J. Leukoc. Biol. 2010, 88, 495-505. [CrossRef]

131. Wang, Y.; Colonna, M. Interkeukin-34, a Cytokine Crucial for the Differentiation and Maintenance of Tissue Resident Macrophages and Langerhans Cells. Eur. J. Immunol. 2014, 44, 1575-1581. [CrossRef] [PubMed]

132. Habtezion, A.; Edderkaoui, M.; Pandol, S.J. Macrophages and Pancreatic Ductal Adenocarcinoma. Cancer Lett. 2016, 381, 211-216. [CrossRef] [PubMed]

133. Huang, C.; Li, Z.; Li, N.; Li, Y.; Chang, A.; Zhao, T.; Wang, X.; Wang, H.; Gao, S.; Yang, S.; et al. Interleukin 35 Expression Correlates with Microvessel Density in Pancreatic Ductal Adenocarcinoma, Recruits Monocytes, and Promotes Growth and Angiogenesis of Xenograft Tumors in Mice. Gastroenterology 2018, 154, 675-688. [CrossRef] [PubMed]

134. Zhu, Y.; Knolhoff, B.L.; Meyer, M.A.; Nywening, T.M.; West, B.L.; Luo, J.; Wang-Gillam, A.; Goedegebuure, S.P.; Linehan, D.C.; DeNardo, D.G. CSF1/CSF1R Blockade Reprograms Tumor-Infiltrating Macrophages and Improves Response to T-Cell Checkpoint Immunotherapy in Pancreatic Cancer Models. Cancer Res. 2014, 74, 5057-5069. [CrossRef] [PubMed]

135. Petty, A.J.; Yang, Y. Tumor-Associated Macrophages: Implications in Cancer Immunotherapy. Immunotherapy 2017, 9, 289-302. [CrossRef] [PubMed]

136. Beatty, G.L.; Winograd, R.; Evans, R.A.; Long, K.B.; Luque, S.L.; Lee, J.W.; Clendenin, C.; Gladney, W.L.; Knoblock, D.M.; Guirnalda, P.D.; et al. Exclusion of T Cells from Pancreatic Carcinomas in Mice Is Regulated by Ly6c(Low) F4/80(+) Extratumoral Macrophages. Gastroenterology 2015, 149, 201-210. [CrossRef] [PubMed]

137. Wu, J.; Li, J.; Salcedo, R.; Mivechi, N.F.; Trinchieri, G.; Horuzsko, A. The Proinflammatory Myeloid Cell Receptor Trem-1 Controls Kupffer Cell Activation and Development of Hepatocellular Carcinoma. Cancer Res 2012, 72, 3977-3986. [CrossRef] [PubMed]

138. Greten, F.R.; Arkan, M.C.; Bollrath, J.; Hsu, L.C.; Goode, J.; Miething, C.; Goktuna, S.I.; Neuenhahn, M.; Fierer, J.; Paxian, S.; et al. NF-Kappa-b Is a Negative Regulator of IL-1beta Secretion as Revealed by Genetic and Pharmacological Inhibition of Ikkbeta. Cell 2007, 130, 918-931. [CrossRef] [PubMed]

139. Zhong, X.; Chen, B.; Yang, Z. The Role of Tumor-Associated Macrophages in Colorectal Carcinoma Progression. Cell Physiol. Biochem. 2018, 45, 356-365. [CrossRef] 
140. Khorana, A.A.; Ryan, C.K.; Cox, C.; Eberly, S.; Sahasrabudhe, D.M. Vascular Endothelial Growth Factor, CD68, and Epidermal Growth Factor Receptor Expression and Survival in Patients with Stage II and Stage III Colon Carcinoma: A Role for the Host Response in Prognosis. Cancer 2003, 97, 960-968. [CrossRef]

141. Esposito, I.; Menicagli, M.; Funel, N.; Bergmann, F.; Boggi, U.; Mosca, F.; Bevilacqua, G.; Campani, D. Inflammatory Cells Contribute to the Generation of an Angiogenic Phenotype in Pancreatic Ductal Adenocarcinoma. J. Clin. Pathol. 2004, 57, 630-636. [CrossRef] [PubMed]

142. Dalton, H.J.; Pradeep, S.; McGuire, M.; Hailemichael, Y.; Ma, S.; Lyons, Y.; Armaiz-Pena, G.N.; Previs, R.A.; Hansen, J.M.; Rupaimoole, R.; et al. Macrophages Facilitate Resistance to Anti-VEGF Therapy by Altered VEGFExpression. Clin. Cancer Res. 2017, 23, 7034-7046. [CrossRef] [PubMed]

143. Bayne, L.J.; Beatty, G.L.; Jhala, N.; Clark, C.E.; Rhim, A.D.; Stanger, B.Z.; Vonderheide, R.H. Tumor-Derived Granulocyte-Macrophage Colony-Stimulating Factor Regulates Myeloid Inflammation and T Cell Immunity in Pancreatic Cancer. Cancer Cell 2012, 21, 822-835. [CrossRef] [PubMed]

144. Qu, P.; Wang, L.Z.; Lin, P.C. Expansion and Functions of Myeloid-Derived Suppressor Cells in the Tumor Microenvironment. Cancer Lett. 2016, 380, 253-256. [CrossRef] [PubMed]

145. Kamran, N.; Li, Y.; Sierra, M.; Alghamri, M.S.; Kadiyala, P.; Appelman, H.D.; Edwards, M.; Lowenstein, P.R.; Castro, M.G. Melanoma Induced Immunosuppression Is Mediated by Hematopoietic Dysregulation. Oncoimmunology 2018, 7, e1408750. [CrossRef] [PubMed]

146. Chang, J.H.; Jiang, Y.; Pillarisetty, V.G. Role of Immune Cells in Pancreatic Cancer from Bench to Clinical Application: An Updated Review. Medicine (Baltimore) 2016, 95, e5541. [CrossRef]

147. Felix, K.; Gaida, M.M. Neutrophil-Derived Proteases in the Microenvironment of Pancreatic Cancer -Active Players in Tumor Progression. Int. J. Biol. Sci. 2016, 12, 302-313. [CrossRef]

148. Movahedi, K.; Guilliams, M.; Van den Bossche, J.; Van den Bergh, R.; Gysemans, C.; Beschin, A.; De Baetselier, P.; Van Ginderachter, J.A. Identification of Discrete Tumor-Induced Myeloid-Derived Suppressor Cell Subpopulations with Distinct T Cell-Suppressive Activity. Blood 2008, 111, 4233-4244. [CrossRef]

149. Bronte, V.; Brandau, S.; Chen, S.H.; Colombo, M.P.; Frey, A.B.; Greten, T.F.; Mandruzzato, S.; Murray, P.J.; Ochoa, A.; Ostrand-Rosenberg, S.; et al. Recommendations for Myeloid-Derived Suppressor Cell Nomenclature and Characterization Standards. Nat. Commun. 2016, 7, 12150. [CrossRef]

150. Karakasheva, T.A.; Dominguez, G.A.; Hashimoto, A.; Lin, E.W.; Chiu, C.; Sasser, K.; Lee, J.W.; Beatty, G.L.; Gabrilovich, D.I.; Rustgi, A.K. CD38+ M-MDSC Expansion Characterizes a Subset of Advanced Colorectal Cancer Patients. JCI Insight 2018, 3. [CrossRef]

151. Porembka, M.R.; Mitchem, J.B.; Belt, B.A.; Hsieh, C.S.; Lee, H.M.; Herndon, J.; Gillanders, W.E.; Linehan, D.C.; Goedegebuure, P. Pancreatic Adenocarcinoma Induces Bone Marrow Mobilization of Myeloid-Derived Suppressor Cells Which Promote Primary Tumor Growth. Cancer Immunol. Immunother. 2012, 61, 1373-1385. [CrossRef] [PubMed]

152. Kapanadze, T.; Gamrekelashvili, J.; Ma, C.; Chan, C.; Zhao, F.; Hewitt, S.; Zender, L.; Kapoor, V.; Felsher, D.W.; Manns, M.P.; et al. Regulation of Accumulation and Function of Myeloid Derived Suppressor Cells in Different Murine Models of Hepatocellular Carcinoma. J. Hepatol. 2013, 59, 1007-1013. [CrossRef] [PubMed]

153. Hoechst, B.; Ormandy, L.A.; Ballmaier, M.; Lehner, F.; Kruger, C.; Manns, M.P.; Greten, T.F.; Korangy, F. A New Population of Myeloid-Derived Suppressor Cells in Hepatocellular Carcinoma Patients Induces CD4(+)CD25(+)Foxp3(+) T Cells. Gastroenterology 2008, 135, 234-243. [CrossRef] [PubMed]

154. Hoechst, B.; Voigtlaender, T.; Ormandy, L.; Gamrekelashvili, J.; Zhao, F.; Wedemeyer, H.; Lehner, F.; Manns, M.P.; Greten, T.F.; Korangy, F. Myeloid Derived Suppressor Cells Inhibit Natural Killer Cells in Patients with Hepatocellular Carcinoma Via the Nkp30 Receptor. Hepatology 2009, 50, 799-807. [CrossRef] [PubMed]

155. Ibrahim, M.L.; Klement, J.D.; Lu, C.; Redd, P.S.; Xiao, W.; Yang, D.; Browning, D.D.; Savage, N.M.; Buckhaults, P.J.; Morse, H.C., 3rd; et al. Myeloid-Derived Suppressor Cells Produce IL-10 to Elicit DNMT3b-Dependent IRF8 Silencing to Promote Colitis-Associated Colon Tumorigenesis. Cell Rep. 2018, 25, 3036-3046. [CrossRef] [PubMed]

156. Guidotti, L.G.; Inverso, D.; Sironi, L.; Di Lucia, P.; Fioravanti, J.; Ganzer, L.; Fiocchi, A.; Vacca, M.; Aiolfi, R.; Sammicheli, S.; et al. Immunosurveillance of the Liver by Intravascular Effector CD8(+) T Cells. Cell 2015, 161, 486-500. [CrossRef] [PubMed]

157. Garrido, F.; Cabrera, T.; Aptsiauri, N. "Hard" and "Soft" Lesions Underlying the HLA Class I Alterations in Cancer Cells: Implications for Immunotherapy. Int. J. Cancer 2010, 127, 249-256. [CrossRef] 
158. Fridman, W.H.; Pages, F.; Sautes-Fridman, C.; Galon, J. The Immune Contexture in Human Tumours: Impact on Clinical Outcome. Nat. Rev. Cancer 2012, 12, 298-306. [CrossRef]

159. Miksch, R.C.; Schoenberg, M.B.; Weniger, M.; Bosch, F.; Ormanns, S.; Mayer, B.; Werner, J.; Bazhin, A.V.; D'Haese, J.G. Prognostic Impact of Tumor-Infiltrating Lymphocytes and Neutrophils on Survival of Patients with Upfront Resection of Pancreatic Cancer. Cancers (Basel) 2019, 11, 39. [CrossRef]

160. Hagland, H.R.; Lea, D.; Watson, M.M.; Soreide, K. Correlation of Blood T-Cells to Intratumoural Density and Location of CD3(+) and CD8(+) T-Cells in Colorectal Cancer. Anticancer. Res. 2017, 37, 675-683. [CrossRef]

161. Xu, X.; Tan, Y.; Qian, Y.; Xue, W.; Wang, Y.; Du, J.; Jin, L.; Ding, W. Clinicopathologic and Prognostic Significance of Tumor-Infiltrating CD8+ T Cells in Patients with Hepatocellular Carcinoma: A Meta-Analysis. Medicine (Baltimore) 2019, 98, e13923. [CrossRef] [PubMed]

162. Ino, Y.; Yamazaki-Itoh, R.; Shimada, K.; Iwasaki, M.; Kosuge, T.; Kanai, Y.; Hiraoka, N. Immune Cell Infiltration as an Indicator of the Immune Microenvironment of Pancreatic Cancer. Br. J. Cancer 2013, 108, 914-923. [CrossRef] [PubMed]

163. Peranzoni, E.; Lemoine, J.; Vimeux, L.; Feuillet, V.; Barrin, S.; Kantari-Mimoun, C.; Bercovici, N.; Guerin, M.; Biton, J.; Ouakrim, H.; et al. Macrophages Impede CD8 T Cells from Reaching Tumor Cells and Limit the Efficacy of Anti-PD-1 Treatment. Proc. Natl. Acad. Sci. USA 2018, 115, E4041-E4050. [CrossRef] [PubMed]

164. Zhang, S.; Zhong, M.; Wang, C.; Xu, Y.; Gao, W.Q.; Zhang, Y. CCL5-Deficiency Enhances Intratumoral Infiltration of CD8(+) T Cells in Colorectal Cancer. Cell Death Dis. 2018, 9, 766. [CrossRef] [PubMed]

165. Katlinski, K.V.; Gui, J.; Katlinskaya, Y.V.; Ortiz, A.; Chakraborty, R.; Bhattacharya, S.; Carbone, C.J.; Beiting, D.P.; Girondo, M.A.; Peck, A.R.; et al. Inactivation of Interferon Receptor Promotes the Establishment of Immune Privileged Tumor Microenvironment. Cancer Cell 2017, 31, 194-207. [CrossRef] [PubMed]

166. Schumacher, T.N.; Schreiber, R.D. Neoantigens in Cancer Immunotherapy. Science 2015, 348, 69-74. [CrossRef] [PubMed]

167. Wang, Y.; Cardell, S.L. The Yin and Yang of Invariant Natural Killer T Cells in Tumor Immunity-Suppression of Tumor Immunity in the Intestine. Front. Immunol. 2017, 8, 1945. [CrossRef]

168. Endig, J.; Buitrago-Molina, L.E.; Marhenke, S.; Reisinger, F.; Saborowski, A.; Schutt, J.; Limbourg, F.; Konecke, C.; Schreder, A.; Michael, A.; et al. Dual Role of the Adaptive Immune System in Liver Injury and Hepatocellular Carcinoma Development. Cancer Cell 2016, 30, 308-323. [CrossRef]

169. Chiang, E.Y.; Kolumam, G.A.; Yu, X.; Francesco, M.; Ivelja, S.; Peng, I.; Gribling, P.; Shu, J.; Lee, W.P.; Refino, C.J.; et al. Targeted Depletion of Lymphotoxin-Alpha-Expressing Th1 and Th17 Cells Inhibits Autoimmune Disease. Nat. Med. 2009, 15, 766-773. [CrossRef]

170. Finkin, S.; Yuan, D.; Stein, I.; Taniguchi, K.; Weber, A.; Unger, K.; Browning, J.L.; Goossens, N.; Nakagawa, S.; Gunasekaran, G.; et al. Ectopic Lymphoid Structures Function as Microniches for Tumor Progenitor Cells in Hepatocellular Carcinoma. Nat. Immunol. 2015, 16, 1235-1244. [CrossRef]

171. Sautes-Fridman, C.; Lawand, M.; Giraldo, N.A.; Kaplon, H.; Germain, C.; Fridman, W.H.; Dieu-Nosjean, M.C. Tertiary Lymphoid Structures in Cancers: Prognostic Value, Regulation, and Manipulation for Therapeutic Intervention. Front. Immunol. 2016, 7, 407. [CrossRef] [PubMed]

172. Protti, M.P.; De Monte, L. Cross-Talk within the Tumor Microenvironment Mediates Th2-Type Inflammation in Pancreatic Cancer. Oncoimmunology 2012, 1, 89-91. [CrossRef] [PubMed]

173. Ling, A.; Lundberg, I.V.; Eklof, V.; Wikberg, M.L.; Oberg, A.; Edin, S.; Palmqvist, R. The Infiltration, and Prognostic Importance, of Th1 Lymphocytes Vary in Molecular Subgroups of Colorectal Cancer. J. Pathol. Clin. Res. 2016, 2, 21-31. [CrossRef] [PubMed]

174. Liu, V.C.; Wong, L.Y.; Jang, T.; Shah, A.H.; Park, I.; Yang, X.; Zhang, Q.; Lonning, S.; Teicher, B.A.; Lee, C. Tumor Evasion of the Immune System by Converting CD4+CD25- T Cells into CD4+CD25+ T Regulatory Cells: Role of Tumor-Derived TGF-Beta. J. Immunol. 2007, 178, 2883-2892. [CrossRef] [PubMed]

175. Hindley, J.P.; Ferreira, C.; Jones, E.; Lauder, S.N.; Ladell, K.; Wynn, K.K.; Betts, G.J.; Singh, Y.; Price, D.A.; Godkin, A.J.; et al. Analysis of the T-Cell Receptor Repertoires of Tumor-Infiltrating Conventional and Regulatory T Cells Reveals No Evidence for Conversion in Carcinogen-Induced Tumors. Cancer Res. 2011, 71, 736-746. [CrossRef]

176. Jarnicki, A.G.; Lysaght, J.; Todryk, S.; Mills, K.H. Suppression of Antitumor Immunity by IL-10 and TGF-Beta-Producing T Cells Infiltrating the Growing Tumor: Influence of Tumor Environment on the Induction of CD4+ and Cd8+ Regulatory T Cells. J. Immunol. 2006, 177, 896-904. [CrossRef] 
177. Correale, P.; Rotundo, M.S.; Del Vecchio, M.T.; Remondo, C.; Migali, C.; Ginanneschi, C.; Tsang, K.Y.; Licchetta, A.; Mannucci, S.; Loiacono, L.; et al. Regulatory (Foxp3+) T-Cell Tumor Infiltration Is a Favorable Prognostic Factor in Advanced Colon Cancer Patients Undergoing Chemo or Chemoimmunotherapy. J. Immunother. 2010, 33, 435-441. [CrossRef]

178. Gao, Q.; Qiu, S.J.; Fan, J.; Zhou, J.; Wang, X.Y.; Xiao, Y.S.; Xu, Y.; Li, Y.W.; Tang, Z.Y. Intratumoral Balance of Regulatory and Cytotoxic T Cells Is Associated with Prognosis of Hepatocellular Carcinoma after Resection. J. Clin. Oncol. 2007, 25, 2586-2593. [CrossRef]

179. Zhang, Y.; Zoltan, M.; Riquelme, E.; Xu, H.; Sahin, I.; Castro-Pando, S.; Montiel, M.F.; Chang, K.; Jiang, Z.; Ling, J.; et al. Immune Cell Production of Interleukin 17 Induces Stem Cell Features of Pancreatic Intraepithelial Neoplasia Cells. Gastroenterology 2018, 155, 210-223. [CrossRef]

180. Razi, S.; Baradaran Noveiry, B.; Keshavarz-Fathi, M.; Rezaei, N. IL-17 and Colorectal Cancer: From Carcinogenesis to Treatment. Cytokine 2019, 116, 7-12. [CrossRef]

181. Gomes, A.L.; Teijeiro, A.; Buren, S.; Tummala, K.S.; Yilmaz, M.; Waisman, A.; Theurillat, J.P.; Perna, C.; Djouder, N. Metabolic Inflammation-Associated IL-17a Causes Non-Alcoholic Steatohepatitis and Hepatocellular Carcinoma. Cancer Cell 2016, 30, 161-175. [CrossRef] [PubMed]

182. Amicarella, F.; Muraro, M.G.; Hirt, C.; Cremonesi, E.; Padovan, E.; Mele, V.; Governa, V.; Han, J.; Huber, X.; Droeser, R.A.; et al. Dual Role of Tumour-Infiltrating T Helper 17 Cells in Human Colorectal Cancer. Gut 2017, 66, 692-704. [CrossRef] [PubMed]

183. Lu, P.H.; Negrin, R.S. A Novel Population of Expanded Human CD3+CD56+ Cells Derived from T Cells with Potent in Vivo Antitumor Activity in Mice with Severe Combined Immunodeficiency. J. Immunol. 1994, 153, 1687-1696. [PubMed]

184. Introna, M.; Franceschetti, M.; Ciocca, A.; Borleri, G.; Conti, E.; Golay, J.; Rambaldi, A. Rapid and Massive Expansion of Cord Blood-Derived Cytokine-Induced Killer Cells: An Innovative Proposal for the Treatment of Leukemia Relapse after Cord Blood Transplantation. Bone Marrow Transplant. 2006, 38, 621-627. [CrossRef] [PubMed]

185. Linn, Y.C.; Lau, L.C.; Hui, K.M. Generation of Cytokine-Induced Killer Cells from Leukaemic Samples with in Vitro Cytotoxicity against Autologous and Allogeneic Leukaemic Blasts. Br. J. Haematol. 2002, 116, 78-86. [CrossRef] [PubMed]

186. Lee, H.K.; Kim, Y.G.; Kim, J.S.; Park, E.J.; Kim, B.; Park, K.H.; Kang, J.S.; Hong, J.T.; Kim, Y.; Han, S.B. Cytokine-Induced Killer Cells Interact with Tumor Lysate-Pulsed Dendritic Cells via CCR5 Signaling. Cancer Lett. 2016, 378, 142-149. [CrossRef] [PubMed]

187. Verneris, M.R.; Karimi, M.; Baker, J.; Jayaswal, A.; Negrin, R.S. Role of NKG2D Signaling in the Cytotoxicity of Activated and Expanded CD8+ T Cells. Blood 2004, 103, 3065-3072. [CrossRef]

188. Schmidt, T.L.; Negrin, R.S.; Contag, C.H. A Killer Choice for Cancer Immunotherapy. Immunol. Res. 2014, 58, 300-306. [CrossRef]

189. Hoffman, W.; Lakkis, F.G.; Chalasani, G. B Cells, Antibodies, and More. Clin. J. Am. Soc. Nephrol. 2016, 11, 137-154. [CrossRef]

190. Lund, F.E.; Hollifield, M.; Schuer, K.; Lines, J.L.; Randall, T.D.; Garvy, B.A. B Cells Are Required for Generation of Protective Effector and Memory CD4 Cells in Response to Pneumocystis Lung Infection. J. Immunol. 2006, 176, 6147-6154. [CrossRef]

191. O’Neill, S.K.; Cao, Y.; Hamel, K.M.; Doodes, P.D.; Hutas, G.; Finnegan, A. Expression of CD80/86 on B Cells is Essential for Autoreactive T Cell Activation and the Development of Arthritis. J. Immunol. 2007, 179, 5109-5116. [CrossRef] [PubMed]

192. Barr, T.A.; Brown, S.; Mastroeni, P.; Gray, D. TLR and B Cell Receptor Signals to B Cells Differentially Program Primary and Memory Th1 Responses to Salmonella Enterica. J. Immunol. 2010, 185, 2783-2789. [CrossRef] [PubMed]

193. Shah, S.; Divekar, A.A.; Hilchey, S.P.; Cho, H.M.; Newman, C.L.; Shin, S.U.; Nechustan, H.; Challita-Eid, P.M.; Segal, B.M.; Yi, K.H.; et al. Increased Rejection of Primary Tumors in Mice Lacking B Cells: Inhibition of Anti-Tumor CTL and Th1 Cytokine Responses by B Cells. Int. J. Cancer 2005, 117, 574-586. [CrossRef] [PubMed]

194. Thorn, M.; Point, G.R.; Burga, R.A.; Nguyen, C.T.; Joseph Espat, N.; Katz, S.C. Liver Metastases Induce Reversible Hepatic B Cell Dysfunction Mediated by Gr-1+CD11b+ Myeloid Cells. J. Leukoc. Biol. 2014, 96, 883-894. [CrossRef] [PubMed] 
195. Xue, H.; Lin, F.; Tan, H.; Zhu, Z.Q.; Zhang, Z.Y.; Zhao, L. Overrepresentation of IL-10-Expressing B Cells Suppresses Cytotoxic CD4+ T Cell Activity in Hbv-Induced Hepatocellular Carcinoma. PLoS ONE 2016, 11, e0154815. [CrossRef] [PubMed]

196. Wejksza, K.; Lee-Chang, C.; Bodogai, M.; Bonzo, J.; Gonzalez, F.J.; Lehrmann, E.; Becker, K.; Biragyn, A. Cancer-Produced Metabolites of 5-Lipoxygenase Induce Tumor-Evoked Regulatory B Cells Via Peroxisome Proliferator-Activated Receptor Alpha. J. Immunol. 2013, 190, 2575-2584. [CrossRef] [PubMed]

197. Khlaiphuengsin, A.; Chuaypen, N.; Pinjaroen, N.; Sirichindakul, B.; Hirankarn, N.; Tangkijvanich, P. Plasma B-Cell Activating Factor Levels and Polymorphisms in Hepatitis B-Related Hepatocellular Carcinoma: Clinical Correlation and Prognosis. Asian Pac. J. Allergy Immunol. 2019.

198. Pylayeva-Gupta, Y.; Das, S.; Handler, J.S.; Hajdu, C.H.; Coffre, M.; Koralov, S.B.; Bar-Sagi, D. IL35-Producing B Cells Promote the Development of Pancreatic Neoplasia. Cancer Discov. 2016, 6, 247-255. [CrossRef]

199. Gunderson, A.J.; Kaneda, M.M.; Tsujikawa, T.; Nguyen, A.V.; Affara, N.I.; Ruffell, B.; Gorjestani, S.; Liudahl, S.M.; Truitt, M.; Olson, P.; et al. Bruton Tyrosine Kinase-Dependent Immune Cell Cross-Talk Drives Pancreas Cancer. Cancer Discov. 2016, 6, 270-285. [CrossRef]

200. Garnelo, M.; Tan, A.; Her, Z.; Yeong, J.; Lim, C.J.; Chen, J.; Lim, K.H.; Weber, A.; Chow, P.; Chung, A.; et al. Interaction between Tumour-Infiltrating B Cells and T Cells Controls the Progression of Hepatocellular Carcinoma. Gut 2017, 66, 342-351. [CrossRef]

201. Schneider, C.; Teufel, A.; Yevsa, T.; Staib, F.; Hohmeyer, A.; Walenda, G.; Zimmermann, H.W.; Vucur, M.; Huss, S.; Gassler, N.; et al. Adaptive Immunity Suppresses Formation and Progression of Diethylnitrosamine-Induced Liver Cancer. Gut 2012, 61, 1733-1743. [CrossRef] [PubMed]

202. Berntsson, J.; Nodin, B.; Eberhard, J.; Micke, P.; Jirstrom, K. Prognostic Impact of Tumour-Infiltrating B Cells and Plasma Cells in Colorectal Cancer. Int. J. Cancer 2016, 139, 1129-1139. [CrossRef] [PubMed]

203. Bassiri, H.; Das, R.; Nichols, K.E. Invariant Nkt Cells: Killers and Conspirators against Cancer. Oncoimmunology 2013, 2, e27440. [CrossRef] [PubMed]

204. Bricard, G.; Cesson, V.; Devevre, E.; Bouzourene, H.; Barbey, C.; Rufer, N.; Im, J.S.; Alves, P.M.; Martinet, O.; Halkic, N.; et al. Enrichment of Human Cd4+ V(Alpha)24/Vbeta11 Invariant Nkt Cells in Intrahepatic Malignant Tumors. J. Immunol. 2009, 182, 5140-5151. [CrossRef] [PubMed]

205. Wolf, M.J.; Adili, A.; Piotrowitz, K.; Abdullah, Z.; Boege, Y.; Stemmer, K.; Ringelhan, M.; Simonavicius, N.; Egger, M.; Wohlleber, D.; et al. Metabolic Activation of Intrahepatic CD8+ T Cells and NKT Cells Causes Nonalcoholic Steatohepatitis and Liver Cancer via Cross-Talk with Hepatocytes. Cancer Cell 2014, 26, 549-564. [CrossRef] [PubMed]

206. Ma, C.; Han, M.; Heinrich, B.; Fu, Q.; Zhang, Q.; Sandhu, M.; Agdashian, D.; Terabe, M.; Berzofsky, J.A.; Fako, V.; et al. Gut Microbiome-Mediated Bile Acid Metabolism Regulates Liver Cancer Via Nkt Cells. Science 2018, 360. [CrossRef] [PubMed]

207. Janakiram, N.B.; Mohammed, A.; Bryant, T.; Ritchie, R.; Stratton, N.; Jackson, L.; Lightfoot, S.; Benbrook, D.M.; Asch, A.S.; Lang, M.L.; et al. Loss of Natural Killer T Cells Promotes Pancreatic Cancer in LSL-Kras(G12d/+) Mice. Immunology 2017, 152, 36-51. [CrossRef] [PubMed]

208. Tachibana, T.; Onodera, H.; Tsuruyama, T.; Mori, A.; Nagayama, S.; Hiai, H.; Imamura, M. Increased Intratumor Valpha24-Positive Natural Killer T Cells: A Prognostic Factor for Primary Colorectal Carcinomas. Clin. Cancer Res. 2005, 11, 7322-7327. [CrossRef]

209. Wang, Y.; Sedimbi, S.; Lofbom, L.; Singh, A.K.; Porcelli, S.A.; Cardell, S.L. Unique Invariant Natural Killer T Cells Promote Intestinal Polyps by Suppressing Th1 Immunity and Promoting Regulatory T Cells. Mucosal Immunol. 2018, 11, 131-143. [CrossRef]

210. Heller, F.; Fuss, I.J.; Nieuwenhuis, E.E.; Blumberg, R.S.; Strober, W. Oxazolone Colitis, a Th2 Colitis Model Resembling Ulcerative Colitis, Is Mediated by IL-13-Producing NK-T Cells. Immunity 2002, 17, 629-638. [CrossRef]

211. Whiteside, T.L. The Role of Regulatory T Cells in Cancer Immunology. Immunotargets Ther. 2015, 4, $159-171$. [CrossRef] [PubMed]

212. Fu, J.; Zhang, Z.; Zhou, L.; Qi, Z.; Xing, S.; Lv, J.; Shi, J.; Fu, B.; Liu, Z.; Zhang, J.Y.; et al. Impairment of CD4+ Cytotoxic T Cells Predicts Poor Survival and High Recurrence Rates in Patients with Hepatocellular Carcinoma. Hepatology 2013, 58, 139-149. [CrossRef] [PubMed] 
213. Hwang, H.K.; Kim, H.I.; Kim, S.H.; Choi, J.; Kang, C.M.; Kim, K.S.; Lee, W.J. Prognostic Impact of the Tumor-Infiltrating Regulatory T-Cell (Foxp3(+))/Activated Cytotoxic T Lymphocyte (Granzyme B(+)) Ratio on Resected Left-Sided Pancreatic Cancer. Oncol. Lett. 2016, 12, 4477-4484. [CrossRef] [PubMed]

214. Carreras, J.; Lopez-Guillermo, A.; Fox, B.C.; Colomo, L.; Martinez, A.; Roncador, G.; Montserrat, E.; Campo, E.; Banham, A.H. High Numbers of Tumor-Infiltrating Foxp3-Positive Regulatory T Cells Are Associated with Improved Overall Survival in Follicular Lymphoma. Blood 2006, 108, 2957-2964. [CrossRef]

215. Frey, D.M.; Droeser, R.A.; Viehl, C.T.; Zlobec, I.; Lugli, A.; Zingg, U.; Oertli, D.; Kettelhack, C.; Terracciano, L.; Tornillo, L. High Frequency of Tumor-Infiltrating Foxp3(+) Regulatory T Cells Predicts Improved Survival in Mismatch Repair-Proficient Colorectal Cancer Patients. Int. J. Cancer 2010, 126, 2635-2643. [CrossRef] [PubMed]

216. Wilke, C.M.; Wu, K.; Zhao, E.; Wang, G.; Zou, W. Prognostic Significance of Regulatory T Cells in Tumor. Int. J. Cancer 2010, 127, 748-758. [CrossRef]

217. Akeus, P.; Langenes, V.; Kristensen, J.; von Mentzer, A.; Sparwasser, T.; Raghavan, S.; Quiding-Jarbrink, M. Treg-Cell Depletion Promotes Chemokine Production and Accumulation of CXCR3(+) Conventional T Cells in Intestinal Tumors. Eur. J. Immunol. 2015, 45, 1654-1666. [CrossRef] [PubMed]

218. Blatner, N.R.; Mulcahy, M.F.; Dennis, K.L.; Scholtens, D.; Bentrem, D.J.; Phillips, J.D.; Ham, S.; Sandall, B.P.; Khan, M.W.; Mahvi, D.M.; et al. Expression of Rorgammat Marks a Pathogenic Regulatory T Cell Subset in Human Colon Cancer. Sci. Transl. Med. 2012, 4, 159. [CrossRef] [PubMed]

219. Sefik, E.; Geva-Zatorsky, N.; Oh, S.; Konnikova, L.; Zemmour, D.; McGuire, A.M.; Burzyn, D.; Ortiz-Lopez, A.; Lobera, M.; Yang, J.; et al. Mucosal Immunology. Individual Intestinal Symbionts Induce a Distinct Population of ROR-gamma(+) Regulatory T Cells. Science 2015, 349, 993-997. [CrossRef]

220. Kim, B.S.; Lu, H.; Ichiyama, K.; Chen, X.; Zhang, Y.B.; Mistry, N.A.; Tanaka, K.; Lee, Y.H.; Nurieva, R.; Zhang, L.; et al. Generation of Rorgammat(+) Antigen-Specific T Regulatory 17 Cells from Foxp3(+) Precursors in Autoimmunity. Cell Rep. 2017, 21, 195-207. [CrossRef]

221. Becht, E.; de Reynies, A.; Giraldo, N.A.; Pilati, C.; Buttard, B.; Lacroix, L.; Selves, J.; Sautes-Fridman, C.; Laurent-Puig, P.; Fridman, W.H. Immune and Stromal Classification of Colorectal Cancer Is Associated with Molecular Subtypes and Relevant for Precision Immunotherapy. Clin. Cancer Res. 2016, 22, 4057-4066. [CrossRef] [PubMed]

222. Parker, J.S.; Mullins, M.; Cheang, M.C.; Leung, S.; Voduc, D.; Vickery, T.; Davies, S.; Fauron, C.; He, X.; $\mathrm{Hu}, \mathrm{Z}$; et al. Supervised Risk Predictor of Breast Cancer Based on Intrinsic Subtypes. J. Clin. Oncol. 2009, 27, 1160-1167. [CrossRef] [PubMed]

223. Guinney, J.; Dienstmann, R.; Wang, X.; de Reynies, A.; Schlicker, A.; Soneson, C.; Marisa, L.; Roepman, P.; Nyamundanda, G.; Angelino, P.; et al. The Consensus Molecular Subtypes of Colorectal Cancer. Nat. Med. 2015, 21, 1350-1356. [CrossRef] [PubMed]

224. Kather, J.N.; Suarez-Carmona, M.; Charoentong, P.; Weis, C.A.; Hirsch, D.; Bankhead, P.; Horning, M.; Ferber, D.; Kel, I.; Herpel, E.; et al. Topography of Cancer-Associated Immune Cells in Human Solid Tumors. eLife 2018, 7. [CrossRef]

225. Lanitis, E.; Dangaj, D.; Irving, M.; Coukos, G. Mechanisms Regulating T-Cell Infiltration and Activity in Solid Tumors. Ann. Oncol. 2017, 28, xii18-xii32. [CrossRef] [PubMed]

226. Apolo, A.B.; Infante, J.R.; Balmanoukian, A.; Patel, M.R.; Wang, D.; Kelly, K.; Mega, A.E.; Britten, C.D.; Ravaud, A.; Mita, A.C.; et al. Avelumab, an Anti-Programmed Death-Ligand 1 Antibody, in Patients with Refractory Metastatic Urothelial Carcinoma: Results from a Multicenter, Phase Ib Study. J. Clin. Oncol. 2017, 35, 2117-2124. [CrossRef]

227. Herbst, R.S.; Baas, P.; Kim, D.W.; Felip, E.; Perez-Gracia, J.L.; Han, J.Y.; Molina, J.; Kim, J.H.; Arvis, C.D.; Ahn, M.J.; et al. Pembrolizumab Versus Docetaxel for Previously Treated, PD-L1-Positive, Advanced Non-Small-Cell Lung Cancer (Keynote-010): A Randomised Controlled Trial. Lancet 2016, 387, 1540-1550. [CrossRef]

228. Remon, J.; Besse, B.; Soria, J.C. Successes and Failures: What Did We Learn from Recent First-Line Treatment Immunotherapy Trials in Non-Small Cell Lung Cancer? BMC Med. 2017, 15, 55.

229. Carbone, D.P.; Reck, M.; Paz-Ares, L.; Creelan, B.; Horn, L.; Steins, M.; Felip, E.; van den Heuvel, M.M.; Ciuleanu, T.E.; Badin, F.; et al. First-Line Nivolumab in Stage IV or Recurrent Non-Small-Cell Lung Cancer. N. Engl. J. Med. 2017, 376, 2415-2426. [CrossRef] 
230. Garon, E.B.; Rizvi, N.A.; Hui, R.; Leighl, N.; Balmanoukian, A.S.; Eder, J.P.; Patnaik, A.; Aggarwal, C.; Gubens, M.; Horn, L.; et al. Pembrolizumab for the Treatment of Non-Small-Cell Lung Cancer. N. Engl. J. Med. 2015, 372, 2018-2028. [CrossRef]

231. Gettinger, S.; Rizvi, N.A.; Chow, L.Q.; Borghaei, H.; Brahmer, J.; Ready, N.; Gerber, D.E.; Shepherd, F.A.; Antonia, S.; Goldman, J.W.; et al. Nivolumab Monotherapy for First-Line Treatment of Advanced Non-Small-Cell Lung Cancer. J. Clin. Oncol. 2016, 34, 2980-2987. [CrossRef] [PubMed]

232. Topalian, S.L.; Hodi, F.S.; Brahmer, J.R.; Gettinger, S.N.; Smith, D.C.; McDermott, D.F.; Powderly, J.D.; Carvajal, R.D.; Sosman, J.A.; Atkins, M.B.; et al. Safety, Activity, and Immune Correlates of Anti-PD-1 Antibody in Cancer. N. Engl. J. Med. 2012, 366, 2443-2454. [CrossRef] [PubMed]

233. Hanna, G.J.; Lizotte, P.; Cavanaugh, M.; Kuo, F.C.; Shivdasani, P.; Frieden, A.; Chau, N.G.; Schoenfeld, J.D.; Lorch, J.H.; Uppaluri, R.; et al. Frameshift Events Predict Anti-PD-1/L1 Response in Head and Neck Cancer. JCI Insight 2018, 3. [CrossRef] [PubMed]

234. Sunshine, J.; Taube, J.M. PD-1/PD-L1 Inhibitors. Curr. Opin. Pharmacol. 2015, 23, 32-38. [CrossRef] [PubMed]

235. Weinberg, B.A.; Hameed, R.; Marshall, J.L. Biomarkers for Immune Therapy in Gastrointestinal Cancers. Clin. Adv. Hematol. Oncol. 2019, 17, 109-119.

236. Havel, J.J.; Chowell, D.; Chan, T.A. The Evolving Landscape of Biomarkers for Checkpoint Inhibitor Immunotherapy. Nat. Rev. Cancer 2019, 19, 133-150. [CrossRef] [PubMed]

237. Tang, H.; Liang, Y.; Anders, R.A.; Taube, J.M.; Qiu, X.; Mulgaonkar, A.; Liu, X.; Harrington, S.M.; Guo, J.; Xin, Y.; et al. Pd-L1 on Host Cells Is Essential for PD-L1 Blockade-Mediated Tumor Regression. J. Clin. Invest. 2018, 128, 580-588. [CrossRef] [PubMed]

238. Chen, D.S.; Mellman, I. Elements of Cancer Immunity and the Cancer-Immune Set Point. Nature 2017, 541, 321-330. [CrossRef] [PubMed]

239. Taylor, N.A.; Vick, S.C.; Iglesia, M.D.; Brickey, W.J.; Midkiff, B.R.; McKinnon, K.P.; Reisdorf, S.; Anders, C.K.; Carey, L.A.; Parker, J.S.; et al. Treg Depletion Potentiates Checkpoint Inhibition in Claudin-Low Breast Cancer. J. Clin. Invest. 2017, 127, 3472-3483. [CrossRef] [PubMed]

240. Salem, M.E.; Xiu, J.; Weinberg, B.A.; El-Deiry, W.S.; Weiner, L.M.; Gatalica, Z.; Liu, Z.; Ghazaly, H.E.; Xiao, N.; Hwang, J.J.; et al. Characterization of Tumor Mutation Burden (TMB) in Gastrointestinal (Gi) Cancers. J. Clin. Oncol. 2017, 35, 530. [CrossRef]

241. Chang, H.; Jung, W.; Kim, A.; Kim, H.K.; Kim, W.B.; Kim, J.H.; Kim, B.H. Expression and Prognostic Significance of Programmed Death Protein 1 and Programmed Death Ligand-1, and Cytotoxic T Lymphocyte-Associated Molecule-4 in Hepatocellular Carcinoma. APMIS 2017, 125, 690-698. [CrossRef] [PubMed]

242. Liu, G.M.; Li, X.G.; Zhang, Y.M. Prognostic Role of PD-L1 for HCC Patients after Potentially Curative Resection: A Meta-Analysis. Cancer Cell Int. 2019, 19, 22. [CrossRef] [PubMed]

243. Blando, J.; Sharma, A.; Higa, M.G.; Zhao, H.; Vence, L.; Yadav, S.S.; Kim, J.; Sepulveda, A.M.; Sharp, M.; Maitra, A.; et al. Comparison of Immune Infiltrates in Melanoma and Pancreatic Cancer Highlights Vista as a Potential Target in Pancreatic Cancer. Proc. Natl. Acad. Sci. USA 2019, 116, 1692-1697. [CrossRef] [PubMed]

244. Salem, M.E.; Puccini, A.; Grothey, A.; Raghavan, D.; Goldberg, R.M.; Xiu, J.; Korn, W.M.; Weinberg, B.A.; Hwang, J.J.; Shields, A.F.; et al. Landscape of Tumor Mutation Load, Mismatch Repair Deficiency, and PD-L1 Expression in a Large Patient Cohort of Gastrointestinal Cancers. Mol. Cancer Res. 2018, 16, 805-812. [CrossRef] [PubMed]

245. Buchhalter, I.; Rempel, E.; Endris, V.; Allgauer, M.; Neumann, O.; Volckmar, A.L.; Kirchner, M.; Leichsenring, J.; Lier, A.; von Winterfeld, M.; et al. Size Matters: Dissecting Key Parameters for Panel-Based Tumor Mutational Burden Analysis. Int. J. Cancer 2019, 144, 848-858. [CrossRef] [PubMed]

246. Fabrizio, D.A.; George, T.J., Jr.; Dunne, R.F.; Frampton, G.; Sun, J.; Gowen, K.; Kennedy, M.; Greenbowe, J.; Schrock, A.B.; Hezel, A.F.; et al. Beyond Microsatellite Testing: Assessment of Tumor Mutational Burden Identifies Subsets of Colorectal Cancer Who May Respond to Immune Checkpoint Inhibition. J. Gastrointest Oncol. 2018, 9, 610-617. [CrossRef] [PubMed]

247. Legrand, F.A.; Gandara, D.R.; Mariathasan, S.; Powles, T.; He, X.; Zhang, W.; Jhunjhunwala, S.; Nickles, D.; Bourgon, R.; Schleifman, E.; et al. Association of High Tissue TMB and Atezolizumab Efficacy across Multiple Tumor Types. J. Clin. Oncol. 2018, 36, 12000. [CrossRef]

248. Balli, D.; Rech, A.J.; Stanger, B.Z.; Vonderheide, R.H. Immune Cytolytic Activity Stratifies Molecular Subsets of Human Pancreatic Cancer. Clin. Cancer Res. 2017, 23, 3129-3138. [CrossRef] [PubMed] 
249. Rizvi, N.A.; Hellmann, M.D.; Snyder, A.; Kvistborg, P.; Makarov, V.; Havel, J.J.; Lee, W.; Yuan, J.; Wong, P.; Ho, T.S.; et al. Cancer Immunology. Mutational Landscape Determines Sensitivity to PD-1 Blockade in Non-Small Cell Lung Cancer. Science 2015, 348, 124-128. [CrossRef]

250. Finotello, F.; Mayer, C.; Plattner, C.; Laschober, G.; Rieder, D.; Hackl, H.; Krogsdam, A.; Loncova, Z.; Posch, W.; Wilflingseder, D.; et al. Molecular and Pharmacological Modulators of the Tumor Immune Contexture Revealed by Deconvolution of RNA-Seq Data. Genome Med. 2019, 11, 34. [CrossRef]

251. McGranahan, N.; Furness, A.J.; Rosenthal, R.; Ramskov, S.; Lyngaa, R.; Saini, S.K.; Jamal-Hanjani, M.; Wilson, G.A.; Birkbak, N.J.; Hiley, C.T.; et al. Clonal Neoantigens Elicit T Cell Immunoreactivity and Sensitivity to Immune Checkpoint Blockade. Science 2016, 351, 1463-1469. [CrossRef] [PubMed]

252. Le, D.T.; Durham, J.N.; Smith, K.N.; Wang, H.; Bartlett, B.R.; Aulakh, L.K.; Lu, S.; Kemberling, H.; Wilt, C.; Luber, B.S.; et al. Mismatch Repair Deficiency Predicts Response of Solid Tumors to PD-1 Blockade. Science 2017, 357, 409-413. [CrossRef] [PubMed]

253. Alexandrov, L.B.; Nik-Zainal, S.; Wedge, D.C.; Aparicio, S.A.; Behjati, S.; Biankin, A.V.; Bignell, G.R.; Bolli, N.; Borg, A.; Borresen-Dale, A.L.; et al. Signatures of Mutational Processes in Human Cancer. Nature 2013, 500, 415-421. [CrossRef] [PubMed]

254. Long, J.; Wang, A.; Bai, Y.; Lin, J.; Yang, X.; Wang, D.; Yang, X.; Jiang, Y.; Zhao, H. Development and Validation of a TP53-Associated Immune Prognostic Model for Hepatocellular Carcinoma. EBioMedicine 2019, 42, 363-374. [CrossRef] [PubMed]

255. Wormann, S.M.; Song, L.; Ai, J.; Diakopoulos, K.N.; Kurkowski, M.U.; Gorgulu, K.; Ruess, D.; Campbell, A.; Doglioni, C.; Jodrell, D.; et al. Loss of P53 Function Activates JAK2-STAT3 Signaling to Promote Pancreatic Tumor Growth, Stroma Modification, and Gemcitabine Resistance in Mice and Is Associated with Patient Survival. Gastroenterology 2016, 151, 180-193. [CrossRef] [PubMed]

256. Cooks, T.; Pateras, I.S.; Jenkins, L.M.; Patel, K.M.; Robles, A.I.; Morris, J.; Forshew, T.; Appella, E.; Gorgoulis, V.G.; Harris, C.C. Mutant P53 Cancers Reprogram Macrophages to Tumor Supporting Macrophages Via Exosomal mir-1246. Nat. Commun. 2018, 9, 771. [CrossRef] [PubMed]

257. Dong, Z.Y.; Zhong, W.Z.; Zhang, X.C.; Su, J.; Xie, Z.; Liu, S.Y.; Tu, H.Y.; Chen, H.J.; Sun, Y.L.; Zhou, Q.; et al. Potential Predictive Value of TP53 and KRAS Mutation Status for Response to PD-1 Blockade Immunotherapy in Lung Adenocarcinoma. Clin. Cancer Res. 2017, 23, 3012-3024. [CrossRef] [PubMed]

258. Agersborg, S.; Jiang, S.; Chen, W.; Ma, W.; Albitar, M. PD-L1 Expression Correlation with TP53 Gene Mutation Status in Lung Cancer but Not in Colorectal Cancer. J. Clin. Oncol. 2016, 34, 11557. [CrossRef]

259. Varchetta, V.; Montagnese, F.; Sibio, S.; Sica, G.; Muscaritoli, M.; Soda, G.; Giordano, G.; Brandi, R.; Tarsi, S.; Mancuso, G.; et al. PD-1/PD-L1 Expression and Regorafenib Clinical Efficacy on Refractory Pancreatic Cancer Patient. J. Clin. Oncol. 2016, 34, e15684. [CrossRef]

260. Liao, W.; Overman, M.J.; Boutin, A.T.; Shang, X.; Zhao, D.; Dey, P.; Li, J.; Wang, G.; Lan, Z.; Li, J.; et al. KRAS-IRF2 Axis Drives Immune Suppression and Immune Therapy Resistance in Colorectal Cancer. Cancer Cell 2019, 35, 559-572. [CrossRef]

261. Atkins, D.; Breuckmann, A.; Schmahl, G.E.; Binner, P.; Ferrone, S.; Krummenauer, F.; Storkel, S.; Seliger, B. MHC Class I Antigen Processing Pathway Defects, RAS Mutations and Disease Stage in Colorectal Carcinoma. Int. J. Cancer 2004, 109, 265-273. [CrossRef] [PubMed]

262. Borghaei, H.; Paz-Ares, L.; Horn, L.; Spigel, D.R.; Steins, M.; Ready, N.E.; Chow, L.Q.; Vokes, E.E.; Felip, E.; Holgado, E.; et al. Nivolumab Versus Docetaxel in Advanced Nonsquamous Non-Small-Cell Lung Cancer. N. Engl. J. Med. 2015, 373, 1627-1639. [CrossRef] [PubMed]

263. Overman, M.J.; McDermott, R.; Leach, J.L.; Lonardi, S.; Lenz, H.J.; Morse, M.A.; Desai, J.; Hill, A.; Axelson, M.; Moss, R.A.; et al. Nivolumab in Patients with Metastatic DNA Mismatch Repair-Deficient or Microsatellite Instability-High Colorectal Cancer (Checkmate 142): An Open-Label, Multicentre, Phase 2 Study. Lancet Oncol. 2017, 18, 1182-1191. [CrossRef]

264. Sivan, A.; Corrales, L.; Hubert, N.; Williams, J.B.; Aquino-Michaels, K.; Earley, Z.M.; Benyamin, F.W.; Lei, Y.M.; Jabri, B.; Alegre, M.L.; et al. Commensal Bifidobacterium Promotes Antitumor Immunity and Facilitates Anti-PD-L1 Efficacy. Science 2015, 350, 1084-1089. [CrossRef] [PubMed]

265. Gopalakrishnan, V.; Spencer, C.N.; Nezi, L.; Reuben, A.; Andrews, M.C.; Karpinets, T.V.; Prieto, P.A.; Vicente, D.; Hoffman, K.; Wei, S.C.; et al. Gut Microbiome Modulates Response to Anti-PD-1 Immunotherapy in Melanoma Patients. Science 2018, 359, 97-103. [CrossRef] 
266. Routy, B.; Le Chatelier, E.; Derosa, L.; Duong, C.P.M.; Alou, M.T.; Daillere, R.; Fluckiger, A.; Messaoudene, M.; Rauber, C.; Roberti, M.P.; et al. Gut Microbiome Influences Efficacy of PD-1-Based Immunotherapy against Epithelial Tumors. Science 2018, 359, 91-97. [CrossRef] [PubMed]

267. Vetizou, M.; Pitt, J.M.; Daillere, R.; Lepage, P.; Waldschmitt, N.; Flament, C.; Rusakiewicz, S.; Routy, B.; Roberti, M.P.; Duong, C.P.; et al. Anticancer Immunotherapy by CTLA-4 Blockade Relies on the Gut Microbiota. Science 2015, 350, 1079-1084. [CrossRef] [PubMed]

268. Hammarstrom, S. The Carcinoembryonic Antigen (Cea) Family: Structures, Suggested Functions and Expression in Normal and Malignant Tissues. Semin Cancer Biol. 1999, 9, 67-81. [CrossRef]

269. Teng, D.; Wu, K.; Sun, Y.; Zhang, M.; Wang, D.; Wu, J.; Yin, T.; Gong, W.; Ding, Y.; Xiao, W.; et al. Significant Increased CA199 Levels in Acute Pancreatitis Patients Predicts the Presence of Pancreatic Cancer. Oncotarget 2018, 9, 12745-12753. [CrossRef]

270. Maude, S.L.; Frey, N.; Shaw, P.A.; Aplenc, R.; Barrett, D.M.; Bunin, N.J.; Chew, A.; Gonzalez, V.E.; Zheng, Z.; Lacey, S.F.; et al. Chimeric Antigen Receptor T Cells for Sustained Remissions in Leukemia. N. Engl. J. Med. 2014, 371, 1507-1517. [CrossRef]

271. Maude, S.L.; Laetsch, T.W.; Buechner, J.; Rives, S.; Boyer, M.; Bittencourt, H.; Bader, P.; Verneris, M.R.; Stefanski, H.E.; Myers, G.D.; et al. Tisagenlecleucel in Children and Young Adults with B-Cell Lymphoblastic Leukemia. N. Engl. J. Med. 2018, 378, 439-448. [CrossRef] [PubMed]

272. Park, J.H.; Riviere, I.; Gonen, M.; Wang, X.; Senechal, B.; Curran, K.J.; Sauter, C.; Wang, Y.; Santomasso, B.; Mead, E.; et al. Long-Term Follow-up of CD19 CAR Therapy in Acute Lymphoblastic Leukemia. N. Engl. J. Med. 2018, 378, 449-459. [CrossRef] [PubMed]

273. Neelapu, S.S.; Locke, F.L.; Bartlett, N.L.; Lekakis, L.J.; Miklos, D.B.; Jacobson, C.A.; Braunschweig, I.; Oluwole, O.O.; Siddiqi, T.; Lin, Y.; et al. Axicabtagene Ciloleucel Car T-Cell Therapy in Refractory Large B-Cell Lymphoma. N. Engl. J. Med. 2017, 377, 2531-2544. [CrossRef] [PubMed]

274. Moon, E.K.; Wang, L.C.; Dolfi, D.V.; Wilson, C.B.; Ranganathan, R.; Sun, J.; Kapoor, V.; Scholler, J.; Pure, E.; Milone, M.C.; et al. Multifactorial T-Cell Hypofunction That Is Reversible Can Limit the Efficacy of Chimeric Antigen Receptor-Transduced Human T Cells in Solid Tumors. Clin. Cancer Res. 2014, 20, 4262-4273. [CrossRef] [PubMed]

275. Parente-Pereira, A.C.; Burnet, J.; Ellison, D.; Foster, J.; Davies, D.M.; van der Stegen, S.; Burbridge, S.; Chiapero-Stanke, L.; Wilkie, S.; Mather, S.; et al. Trafficking of CAR-Engineered Human T Cells Following Regional or Systemic Adoptive Transfer in Scid Beige Mice. J. Clin. Immunol. 2011, 31, 710-718. [CrossRef] [PubMed]

276. Kakarla, S.; Gottschalk, S. CAR T Cells for Solid Tumors: Armed and Ready to Go? Cancer J. 2014, 20, 151-155. [CrossRef] [PubMed]

277. Park, J.R.; Digiusto, D.L.; Slovak, M.; Wright, C.; Naranjo, A.; Wagner, J.; Meechoovet, H.B.; Bautista, C.; Chang, W.C.; Ostberg, J.R.; et al. Adoptive Transfer of Chimeric Antigen Receptor Re-Directed Cytolytic T Lymphocyte Clones in Patients with Neuroblastoma. Mol. Ther. 2007, 15, 825-833. [CrossRef]

278. Lamers, C.H.; Sleijfer, S.; van Steenbergen, S.; van Elzakker, P.; van Krimpen, B.; Groot, C.; Vulto, A.; den Bakker, M.; Oosterwijk, E.; Debets, R.; et al. Treatment of Metastatic Renal Cell Carcinoma with Caix CAR-Engineered T Cells: Clinical Evaluation and Management of on-Target Toxicity. Mol. Ther. 2013, 21, 904-912. [CrossRef]

279. Tokarew, N.; Ogonek, J.; Endres, S.; von Bergwelt-Baildon, M.; Kobold, S. Teaching an Old Dog New Tricks: Next-Generation Car T Cells. Br. J. Cancer 2019, 120, 26-37. [CrossRef]

280. Tahmasebi, S.; Elahi, R.; Esmaeilzadeh, A. Solid Tumors Challenges and New Insights of CAR T Cell Engineering. Stem. Cell Rev. 2019. [CrossRef]

281. Martinez, M.; Moon, E.K. Car T Cells for Solid Tumors: New Strategies for Finding, Infiltrating, and Surviving in the Tumor Microenvironment. Front. Immunol. 2019, 10, 128. [CrossRef] [PubMed]

282. Zhai, B.; Shi, D.; Gao, H.; Qi, X.; Jiang, H.; Zhang, Y.; Chi, J.; Ruan, H.; Wang, H.; Ru, Q.C.; et al. A Phase I Study of Anti-GPC3 Chimeric Antigen Receptor Modified T Cells (GPC3 CAR-T) in Chinese Patients with Refractory or Relapsed GPC3+ Hepatocellular Carcinoma (R/R GPC3+ Hcc). J. Clin. Oncol. 2017, 35, 3049. [CrossRef]

283. Zhang, C.; Wang, Z.; Yang, Z.; Wang, M.; Li, S.; Li, Y.; Zhang, R.; Xiong, Z.; Wei, Z.; Shen, J.; et al. Phase I Escalating-Dose Trial of Car-T Therapy Targeting CEA(+) Metastatic Colorectal Cancers. Mol. Ther. 2017, 25, 1248-1258. [CrossRef] [PubMed] 
284. Feng, K.; Liu, Y.; Guo, Y.; Qiu, J.; Wu, Z.; Dai, H.; Yang, Q.; Wang, Y.; Han, W. Phase I Study of Chimeric Antigen Receptor Modified T Cells in Treating Her2-Positive Advanced Biliary Tract Cancers and Pancreatic Cancers. Protein Cell 2018, 9, 838-847. [CrossRef] [PubMed]

285. Wang, Y.; Chen, M.; Wu, Z.; Tong, C.; Dai, H.; Guo, Y.; Liu, Y.; Huang, J.; Lv, H.; Luo, C.; et al. CD133-Directed Car T Cells for Advanced Metastasis Malignancies: A Phase I Trial. Oncoimmunology 2018, 7, e1440169. [CrossRef] [PubMed]

286. Fukuoka, S.; Hara, H.; Takahashi, N.; Kojima, T.; Kawazoe, A.; Asayama, M.; Yoshii, T.; Kotani, D.; Tamura, H.; Mikamoto, Y.; et al. Regorafenib Plus Nivolumab in Patients with Advanced Gastric (Gc) or Colorectal Cancer (Crc): An Open-Label, Dose-Finding, and Dose-Expansion Phase 1b Trial (Regonivo, Epoc1603). J. Clin. Oncol. 2019, 37, 2522. [CrossRef]

287. Eng, C.; Kim, T.W.; Bendell, J.; Argiles, G.; Tebbutt, N.C.; Di Bartolomeo, M.; Falcone, A.; Fakih, M.; Kozloff, M.; Segal, N.H.; et al. Atezolizumab with or without Cobimetinib Versus Regorafenib in Previously Treated Metastatic Colorectal Cancer (Imblaze370): A Multicentre, Open-Label, Phase 3, Randomised, Controlled Trial. Lancet Oncol. 2019, 20, 849-861. [CrossRef]

288. Adotevi, O.; Godet, Y.; Galaine, J.; Lakkis, Z.; Idirene, I.; Certoux, J.M.; Jary, M.; Loyon, R.; Laheurte, C.; Kim, S.; et al. In Situ Delivery of Allogeneic Natural Killer Cell (NK) Combined with Cetuximab in Liver Metastases of Gastrointestinal Carcinoma: A Phase I Clinical Trial. Oncoimmunology 2018, 7, e1424673. [CrossRef]

289. Le, D.T.; Ko, A.H.; Wainberg, Z.A.; Picozzi, V.J.; Kindler, H.L.; Wang-Gillam, A.; Oberstein, P.E.; Morse, M.; Zeh, H.; Weekes, C.D.; et al. Results from a Phase 2b, Randomized, Multicenter Study of Gvax Pancreas and CRS-207 Compared to Chemotherapy in Adults with Previously-Treated Metastatic Pancreatic Adenocarcinoma (Eclipse Study). J. Clin. Oncol. 2017, 35, 345. [CrossRef]

290. Kebenko, M.; Goebeler, M.E.; Wolf, M.; Hasenburg, A.; Seggewiss-Bernhardt, R.; Ritter, B.; Rautenberg, B.; Atanackovic, D.; Kratzer, A.; Rottman, J.B.; et al. A Multicenter Phase 1 Study of Solitomab (MT110, AMG 110), a Bispecific EPCAM/CD3 T-Cell Engager (Bite(R)) Antibody Construct, in Patients with Refractory Solid Tumors. Oncoimmunology 2018, 7, e1450710. [CrossRef]

291. Bentebibel, S.E.; Hurwitz, M.E.; Bernatchez, C.; Haymaker, C.; Hudgens, C.W.; Kluger, H.M.; Tetzlaff, M.T.; Tagliaferri, M.A.; Zalevsky, J.; Hoch, U.; et al. A First-in-Human Study and Biomarker Analysis of NKTR-214, a Novel Il2rbetagamma-Biased Cytokine, in Patients with Advanced or Metastatic Solid Tumors. Cancer Discov. 2019, 9, 711-721. [CrossRef] [PubMed]

292. Gomez-Roca, C.A.; Italiano, A.; Le Tourneau, C.; Cassier, P.A.; Toulmonde, M.; D'Angelo, S.P.; Campone, M.; Weber, K.L.; Loirat, D.; Cannarile, M.A.; et al. Phase I Study of Emactuzumab Single Agent or in Combination with Paclitaxel in Patients with Advanced/Metastatic Solid Tumors Reveals Depletion of Immunosuppressive M2-Like Macrophages. Ann. Oncol. 2019, 30, 1381-1392. [CrossRef]

293. Liu, H.; Xu, Y.; Xiang, J.; Long, L.; Green, S.; Yang, Z.; Zimdahl, B.; Lu, J.; Cheng, N.; Horan, L.H.; et al. Targeting Alpha-Fetoprotein (AFP)-Mhc Complex with Car T-Cell Therapy for Liver Cancer. Clin. Cancer Res. 2017, 23, 478-488. [CrossRef] [PubMed]

294. Rosenberg, S.A.; Yannelli, J.R.; Yang, J.C.; Topalian, S.L.; Schwartzentruber, D.J.; Weber, J.S.; Parkinson, D.R.; Seipp, C.A.; Einhorn, J.H.; White, D.E. Treatment of Patients with Metastatic Melanoma with Autologous Tumor-Infiltrating Lymphocytes and Interleukin 2. J. Natl. Cancer Inst. 1994, 86, 1159-1166. [CrossRef] [PubMed]

295. Hinrichs, C.S.; Rosenberg, S.A. Exploiting the Curative Potential of Adoptive T-Cell Therapy for Cancer. Immunol. Rev. 2014, 257, 56-71. [CrossRef] [PubMed]

296. Verdegaal, E.M. Adoptive Cell Therapy: A Highly Successful Individualized Therapy for Melanoma with Great Potential for Other Malignancies. Curr. Opin. Immunol. 2016, 39, 90-95. [CrossRef] [PubMed]

297. Dudley, M.E.; Gross, C.A.; Langhan, M.M.; Garcia, M.R.; Sherry, R.M.; Yang, J.C.; Phan, G.Q.; Kammula, U.S.; Hughes, M.S.; Citrin, D.E.; et al. Cd8+ Enriched "Young" Tumor Infiltrating Lymphocytes Can Mediate Regression of Metastatic Melanoma. Clin. Cancer Res. 2010, 16, 6122-6131. [CrossRef] [PubMed]

298. Yossef, R.; Tran, E.; Deniger, D.C.; Gros, A.; Pasetto, A.; Parkhurst, M.R.; Gartner, J.J.; Prickett, T.D.; Cafri, G.; Robbins, P.F.; et al. Enhanced Detection of Neoantigen-Reactive T Cells Targeting Unique and Shared Oncogenes for Personalized Cancer Immunotherapy. JCI Insight 2018, 3. [CrossRef] [PubMed] 
299. Deschoolmeester, V.; Baay, M.; Van Marck, E.; Weyler, J.; Vermeulen, P.; Lardon, F.; Vermorken, J.B. Tumor Infiltrating Lymphocytes: An Intriguing Player in the Survival of Colorectal Cancer Patients. BMC Immunol. 2010, 11, 19. [CrossRef] [PubMed]

300. Geukes Foppen, M.H.; Donia, M.; Svane, I.M.; Haanen, J.B. Tumor-Infiltrating Lymphocytes for the Treatment of Metastatic Cancer. Mol. Oncol. 2015, 9, 1918-1935. [CrossRef] [PubMed]

301. Tran, E.; Ahmadzadeh, M.; Lu, Y.C.; Gros, A.; Turcotte, S.; Robbins, P.F.; Gartner, J.J.; Zheng, Z.; Li, Y.F.; Ray, S.; et al. Immunogenicity of Somatic Mutations in Human Gastrointestinal Cancers. Science 2015, 350, 1387-1390. [CrossRef]

302. Chen, T.H.; Zhang, Y.C.; Tan, Y.T.; An, X.; Xue, C.; Deng, Y.F.; Yang, W.; Yuan, X.; Shi, Y.X. Tumor-Infiltrating Lymphocytes Predict Prognosis of Breast Cancer Patients Treated with Anti-Her-2 Therapy. Oncotarget 2017, 8, 5219-5232. [CrossRef]

303. Pruneri, G.; Gray, K.P.; Vingiani, A.; Viale, G.; Curigliano, G.; Criscitiello, C.; Lang, I.; Ruhstaller, T.; Gianni, L.; Goldhirsch, A.; et al. Tumor-Infiltrating Lymphocytes (TILS) Are a Powerful Prognostic Marker in Patients with Triple-Negative Breast Cancer Enrolled in the Ibcsg Phase III Randomized Clinical Trial 22-00. Breast Cancer Res. Treat. 2016, 158, 323-331. [CrossRef] [PubMed]

304. Tran, E.; Turcotte, S.; Gros, A.; Robbins, P.F.; Lu, Y.C.; Dudley, M.E.; Wunderlich, J.R.; Somerville, R.P.; Hogan, K.; Hinrichs, C.S.; et al. Cancer Immunotherapy Based on Mutation-Specific CD4+ T Cells in a Patient with Epithelial Cancer. Science 2014, 344, 641-645. [CrossRef] [PubMed]

305. Tran, E.; Robbins, P.F.; Lu, Y.C.; Prickett, T.D.; Gartner, J.J.; Jia, L.; Pasetto, A.; Zheng, Z.; Ray, S.; Groh, E.M.; et al. T-Cell Transfer Therapy Targeting Mutant KRAS in Cancer. N. Engl. J. Med. 2016, 375, 2255-2262. [CrossRef]

306. Cafri, G.; Yossef, R.; Pasetto, A.; Deniger, D.C.; Lu, Y.C.; Parkhurst, M.; Gartner, J.J.; Jia, L.; Ray, S.; Ngo, L.T.; et al. Memory T Cells Targeting Oncogenic Mutations Detected in Peripheral Blood of Epithelial Cancer Patients. Nat. Commun. 2019, 10, 449. [CrossRef] [PubMed]

307. Malekzadeh, P.; Pasetto, A.; Robbins, P.F.; Parkhurst, M.R.; Paria, B.C.; Jia, L.; Gartner, J.J.; Hill, V.; Yu, Z.; Restifo, N.P.; et al. Neoantigen Screening Identifies Broad TP53 Mutant Immunogenicity in Patients with Epithelial Cancers. J. Clin. Invest. 2019, 129, 1109-1114. [CrossRef]

308. Ahmadzadeh, M.; Johnson, L.A.; Heemskerk, B.; Wunderlich, J.R.; Dudley, M.E.; White, D.E.; Rosenberg, S.A. Tumor Antigen-Specific CD8 T Cells Infiltrating the Tumor Express High Levels of PD-1 and Are Functionally Impaired. Blood 2009, 114, 1537-1544. [CrossRef] [PubMed]

309. Baitsch, L.; Baumgaertner, P.; Devevre, E.; Raghav, S.K.; Legat, A.; Barba, L.; Wieckowski, S.; Bouzourene, H.; Deplancke, B.; Romero, P.; et al. Exhaustion of Tumor-Specific CD8(+) T Cells in Metastases from Melanoma Patients. J. Clin. Invest. 2011, 121, 2350-2360. [CrossRef] [PubMed]

310. Saito, H.; Okita, K.; Fusaki, N.; Sabel, M.S.; Chang, A.E.; Ito, F. Reprogramming of Melanoma Tumor-Infiltrating Lymphocytes to Induced Pluripotent Stem Cells. Stem Cells Int. 2016, 2016, 8394960. [CrossRef]

311. Rosenberg, S.A.; Tran, E.; Robbins, P.F. T-Cell Transfer Therapy Targeting Mutant KRAS. N. Engl. J. Med. 2017, 376, e11. [PubMed]

312. Li, Q.Y.; Shi, Y.; Huang, D.H.; Yang, T.; Wang, J.H.; Yan, G.H.; Wang, H.Y.; Tang, X.J.; Xiao, C.Y.; Zhang, W.J.; et al. Cytokine-Induced Killer Cells Combined with Dendritic Cells Inhibited Liver Cancer Cells. Int. J. Clin. Exp. Med. 2015, 8, 5601-5610. [PubMed]

313. He, W.; Huang, Z.; Zhou, S.; Huang, L.; Wang, B.; Zhu, L.; Ding, Y.; Yu, Y.L.; Zhang, S. The Effect of DC+CIK Combined Therapy on Rat Liver Cancer Model and Its Modulatory Effect on Immune Functions. Eur Rev. Med. Pharmacol. Sci. 2018, 22, 778-785.

314. Zhang, J.; Li, H.; Gao, D.; Zhang, B.; Zheng, M.; Lun, M.; Wei, M.; Duan, R.; Guo, M.; Hua, J.; et al. A Prognosis and Impact Factor Analysis of DC-CIK Cell Therapy for Patients with Hepatocellular Carcinoma Undergoing Postoperative Tace. Cancer Biol. Ther. 2018, 19, 475-483. [CrossRef] [PubMed]

315. Zhou, Z.; Qin, H.; Weng, L.; Ni, Y. Clinical Efficacy of DC-CIK Combined with Sorafenib in the Treatment of Advanced Hepatocellular Carcinoma. J. BUON 2019, 24, 615-621. [PubMed]

316. Zhu, H.; Yang, X.; Li, J.; Ren, Y.; Zhang, T.; Zhang, C.; Zhang, J.; Li, J.; Pang, Y. Immune Response, Safety, and Survival and Quality of Life Outcomes for Advanced Colorectal Cancer Patients Treated with Dendritic Cell Vaccine and Cytokine-Induced Killer Cell Therapy. Biomed. Res. Int. 2014, 2014, 603871. [CrossRef] [PubMed] 
317. Gao, D.; Li, C.; Xie, X.; Zhao, P.; Wei, X.; Sun, W.; Liu, H.C.; Alexandrou, A.T.; Jones, J.; Zhao, R.; et al. Autologous Tumor Lysate-Pulsed Dendritic Cell Immunotherapy with Cytokine-Induced Killer Cells Improves Survival in Gastric and Colorectal Cancer Patients. PLoS ONE 2014, 9, e93886. [CrossRef] [PubMed]

318. Kim, J.S.; Kim, Y.G.; Park, E.J.; Kim, B.; Lee, H.K.; Hong, J.T.; Kim, Y.; Han, S.B. Cell-Based Immunotherapy for Colorectal Cancer with Cytokine-Induced Killer Cells. Immune. Netw. 2016, 16, 99-108. [CrossRef]

319. Zhang, Y.; Zhang, X.; Zhang, A.; Li, K.; Qu, K. Clinical Applications of Dendritic Cells-Cytokine-Induced Killer Cells Mediated Immunotherapy for Pancreatic Cancer: An up-to-Date Meta-Analysis. Onco. Targets Ther. 2017, 10, 4173-4192. [CrossRef]

320. Wang, Z.; Liu, Y.; Li, R.; Shang, Y.; Zhang, Y.; Zhao, L.; Li, W.; Yang, Y.; Zhang, X.; Yang, T.; et al. Autologous Cytokine-Induced Killer Cell Transfusion Increases Overall Survival in Advanced Pancreatic Cancer. J. Hematol. Oncol. 2016, 9, 6. [CrossRef]

321. Lee, J.H.; Lee, J.H.; Lim, Y.S.; Yeon, J.E.; Song, T.J.; Yu, S.J.; Gwak, G.Y.; Kim, K.M.; Kim, Y.J.; Lee, J.W.; et al. Adjuvant Immunotherapy with Autologous Cytokine-Induced Killer Cells for Hepatocellular Carcinoma. Gastroenterology 2015, 148, 1383-1391. [CrossRef] [PubMed]

322. Kellner, C.; Peipp, M.; Valerius, T. Effector Cell Recruitment by Bispecific Antibodies. In Bispecific Antibodies; Kontermann, R.E., Ed.; Springer: Berlin/Heidelberg, Germany, 2011; pp. 217-241.

323. Kantarjian, H.; Stein, A.; Gokbuget, N.; Fielding, A.K.; Schuh, A.C.; Ribera, J.M.; Wei, A.; Dombret, H.; Foa, R.; Bassan, R.; et al. Blinatumomab Versus Chemotherapy for Advanced Acute Lymphoblastic Leukemia. $N$. Engl. J. Med. 2017, 376, 836-847. [CrossRef] [PubMed]

324. Moek, K.L.; Fiedler, W.M.; von Einem, J.C.; Verheul, H.M.; Seufferlein, T.; de Groot, D.J.; Heinemann, V.; Kebenko, M.; Menke-van der Houven van Oordt, C.W.; Ettrich, T.J.; et al. 427p phase I Study of Amg 211/Medi-565 Administered as Continuous Intravenous Infusion (CIV) for Relapsed/Refractory Gastrointestinal (Gi) Adenocarcinoma. Ann. Oncol. 2018, 29. [CrossRef]

325. Dougan, M.; Dranoff, G.; Dougan, S.K. Cancer Immunotherapy: Beyond Checkpoint Blockade. Annu. Rev. Cancer Biol. 2019, 3, 55-75. [CrossRef]

326. Kreiter, S.; Vormehr, M.; van de Roemer, N.; Diken, M.; Lower, M.; Diekmann, J.; Boegel, S.; Schrors, B.; Vascotto, F.; Castle, J.C.; et al. Mutant MHC Class II Epitopes Drive Therapeutic Immune Responses to Cancer. Nature 2015, 520, 692-696. [CrossRef]

327. Stevanovic, S.; Pasetto, A.; Helman, S.R.; Gartner, J.J.; Prickett, T.D.; Howie, B.; Robins, H.S.; Robbins, P.F.; Klebanoff, C.A.; Rosenberg, S.A.; et al. Landscape of Immunogenic Tumor Antigens in Successful Immunotherapy of Virally Induced Epithelial Cancer. Science 2017, 356, 200-205. [CrossRef]

328. Wong, K.K.; Li, W.A.; Mooney, D.J.; Dranoff, G. Advances in Therapeutic Cancer Vaccines. Adv. Immunol. 2016, 130, 191-249.

329. Ott, P.A.; Hu, Z.; Keskin, D.B.; Shukla, S.A.; Sun, J.; Bozym, D.J.; Zhang, W.; Luoma, A.; Giobbie-Hurder, A.; Peter, L.; et al. An Immunogenic Personal Neoantigen Vaccine for Patients with Melanoma. Nature 2017, 547, 217-221. [CrossRef]

330. Martin, S.D.; Brown, S.D.; Wick, D.A.; Nielsen, J.S.; Kroeger, D.R.; Twumasi-Boateng, K.; Holt, R.A.; Nelson, B.H. Low Mutation Burden in Ovarian Cancer May Limit the Utility of Neoantigen-Targeted Vaccines. PLoS ONE 2016, 11, e0155189. [CrossRef]

331. Cappello, P.; Curcio, C.; Mandili, G.; Roux, C.; Bulfamante, S.; Novelli, F. Next Generation Immunotherapy for Pancreatic Cancer: DNA Vaccination Is Seeking New Combo Partners. Cancers (Basel) 2018, 10, 51. [CrossRef]

332. Snook, A.E.; Baybutt, T.R.; Xiang, B.; Abraham, T.S.; Flickinger, J.C., Jr.; Hyslop, T.; Zhan, T.; Kraft, W.K.; Sato, T.; Waldman, S.A. Split Tolerance Permits Safe Ad5-Gucy2c-Padre Vaccine-Induced T-Cell Responses in Colon Cancer Patients. J. Immunother. Cancer 2019, 7, 104. [CrossRef] [PubMed]

333. Ablasser, A.; Goldeck, M.; Cavlar, T.; Deimling, T.; Witte, G.; Rohl, I.; Hopfner, K.P.; Ludwig, J.; Hornung, V. Cgas Produces a 2'-5'-Linked Cyclic Dinucleotide Second Messenger That Activates Sting. Nature 2013, 498, 380-384. [CrossRef] [PubMed]

334. Chan, Y.K.; Gack, M.U. Viral Evasion of Intracellular DNA and Rna Sensing. Nat. Rev. Microbiol. 2016, 14, 360-373. [CrossRef] [PubMed]

335. Hu, J.C.; Coffin, R.S.; Davis, C.J.; Graham, N.J.; Groves, N.; Guest, P.J.; Harrington, K.J.; James, N.D.; Love, C.A.; McNeish, I.; et al. A Phase I Study of Oncovex GM-CSF, a Second-Generation Oncolytic Herpes 
Simplex Virus Expressing Granulocyte Macrophage Colony-Stimulating Factor. Clin. Cancer Res. 2006, 12, 6737-6747. [CrossRef] [PubMed]

336. Senzer, N.N.; Kaufman, H.L.; Amatruda, T.; Nemunaitis, M.; Reid, T.; Daniels, G.; Gonzalez, R.; Glaspy, J.; Whitman, E.; Harrington, K.; et al. Phase II Clinical Trial of a Granulocyte-Macrophage Colony-Stimulating Factor-Encoding, Second-Generation Oncolytic Herpesvirus in Patients with Unresectable Metastatic Melanoma. J. Clin. Oncol. 2009, 27, 5763-5771. [CrossRef] [PubMed]

337. Harrington, K.J.; Andtbacka, R.H.; Collichio, F.; Downey, G.; Chen, L.; Szabo, Z.; Kaufman, H.L. Efficacy and Safety of Talimogene Laherparepvec Versus Granulocyte-Macrophage Colony-Stimulating Factor in Patients with Stage III b/C and IVM1a Melanoma: Subanalysis of the Phase Iii Optim Trial. Onco. Targets Ther. 2016, 9, 7081-7093. [CrossRef] [PubMed]

338. Andtbacka, R.H.I.; Collichio, F.; Harrington, K.J.; Middleton, M.R.; Downey, G.; hrling, K.; Kaufman, H.L. Final Analyses of Optim: A Randomized Phase III Trial of Talimogene Laherparepvec Versus Granulocyte-Macrophage Colony-Stimulating Factor in Unresectable Stage III-IV Melanoma. J. Immunother. Cancer 2019, 7, 145. [CrossRef]

339. Chesney, J.; Puzanov, I.; Collichio, F.; Singh, P.; Milhem, M.M.; Glaspy, J.; Hamid, O.; Ross, M.; Friedlander, P.; Garbe, C.; et al. Randomized, Open-Label Phase II Study Evaluating the Efficacy and Safety of Talimogene Laherparepvec in Combination with Ipilimumab Versus Ipilimumab Alone in Patients with Advanced, Unresectable Melanoma. J. Clin. Oncol. 2018, 36, 1658-1667. [CrossRef]

340. Hecht, J.R.; Bedford, R.; Abbruzzese, J.L.; Lahoti, S.; Reid, T.R.; Soetikno, R.M.; Kirn, D.H.; Freeman, S.M. A Phase I/II Trial of Intratumoral Endoscopic Ultrasound Injection of Onyx-015 with Intravenous Gemcitabine in Unresectable Pancreatic Carcinoma. Clin. Cancer Res. 2003, 9, 555-561.

341. Samson, A.; Bentham, M.J.; Scott, K.; Nuovo, G.; Bloy, A.; Appleton, E.; Adair, R.A.; Dave, R.; Peckham-Cooper, A.; Toogood, G.; et al. Oncolytic Reovirus as a Combined Antiviral and Anti-Tumour Agent for the Treatment of Liver Cancer. Gut 2018, 67, 562-573. [CrossRef]

342. Senzer, N.; Barve, M.; Kuhn, J.; Melnyk, A.; Beitsch, P.; Lazar, M.; Lifshitz, S.; Magee, M.; Oh, J.; Mill, S.W.; et al. Phase I Trial of "Bi-ShRNAi (Furin)/GMCSF DNA/Autologous Tumor Cell” Vaccine (FANG) in Advanced Cancer. Mol. Ther. 2012, 20, 679-686. [CrossRef]

343. Zhang, H.; Li, K.; Lin, Y.; Xing, F.; Xiao, X.; Cai, J.; Zhu, W.; Liang, J.; Tan, Y.; Fu, L.; et al. Targeting Vcp Enhances Anticancer Activity of Oncolytic Virus M1 in Hepatocellular Carcinoma. Sci. Transl. Med. 2017, 9. [CrossRef]

344. Royal, R.E.; Levy, C.; Turner, K.; Mathur, A.; Hughes, M.; Kammula, U.S.; Sherry, R.M.; Topalian, S.L.; Yang, J.C.; Lowy, I.; et al. Phase 2 Trial of Single Agent Ipilimumab (Anti-CTLA-4) for Locally Advanced or Metastatic Pancreatic Adenocarcinoma. J. Immunother. 2010, 33, 828-833. [CrossRef]

345. Sangro, B.; Gomez-Martin, C.; de la Mata, M.; Inarrairaegui, M.; Garralda, E.; Barrera, P.; Riezu-Boj, J.I.; Larrea, E.; Alfaro, C.; Sarobe, P.; et al. A Clinical Trial of CTLA-4 Blockade with Tremelimumab in Patients with Hepatocellular Carcinoma and Chronic Hepatitis, C. J. Hepatol. 2013, 59, 81-88. [CrossRef]

346. Topalian, S.L.; Drake, C.G.; Pardoll, D.M. Immune Checkpoint Blockade: A Common Denominator Approach to Cancer Therapy. Cancer Cell 2015, 27, 450-461. [CrossRef]

347. Postow, M.A.; Callahan, M.K.; Wolchok, J.D. Immune Checkpoint Blockade in Cancer Therapy. J. Clin. Oncol. 2015, 33, 1974-1982. [CrossRef]

348. Lupinacci, R.M.; Goloudina, A.; Buhard, O.; Bachet, J.B.; Marechal, R.; Demetter, P.; Cros, J.; Bardier-Dupas, A.; Collura, A.; Cervera, P.; et al. Prevalence of Microsatellite Instability in Intraductal Papillary Mucinous Neoplasms of the Pancreas. Gastroenterology 2018, 154, 1061-1065. [CrossRef]

349. Mellman, I.; Hubbard-Lucey, V.M.; Tontonoz, M.J.; Kalos, M.D.; Chen, D.S.; Allison, J.P.; Drake, C.G.; Levitsky, H.; Lonberg, N.; van der Burg, S.H.; et al. De-Risking Immunotherapy: Report of a Consensus Workshop of the Cancer Immunotherapy Consortium of the Cancer Research Institute. Cancer Immunol. Res. 2016, 4, 279-288. [CrossRef]

350. Baumeister, S.H.; Freeman, G.J.; Dranoff, G.; Sharpe, A.H. Coinhibitory Pathways in Immunotherapy for Cancer. Annu. Rev. Immunol. 2016, 34, 539-573. [CrossRef]

351. Duffy, A.G.; Ulahannan, S.V.; Makorova-Rusher, O.; Rahma, O.; Wedemeyer, H.; Pratt, D.; Davis, J.L.; Hughes, M.S.; Heller, T.; ElGindi, M.; et al. Tremelimumab in Combination with Ablation in Patients with Advanced Hepatocellular Carcinoma. J. Hepatol. 2017, 66, 545-551. [CrossRef] 
352. Della Chiesa, M.; Pesce, S.; Muccio, L.; Carlomagno, S.; Sivori, S.; Moretta, A.; Marcenaro, E. Features of Memory-Like and PD-1(+) Human NK Cell Subsets. Front. Immunol 2016, 7, 351. [CrossRef]

353. Benson, D.M., Jr.; Cohen, A.D.; Jagannath, S.; Munshi, N.C.; Spitzer, G.; Hofmeister, C.C.; Efebera, Y.A.; Andre, P.; Zerbib, R.; Caligiuri, M.A. A Phase I Trial of the Anti-KIR Antibody IPH2101 and Lenalidomide in Patients with Relapsed/Refractory Multiple Myeloma. Clin. Cancer Res. 2015, 21, 4055-4061. [CrossRef]

354. Zaghi, E.; Calvi, M.; Marcenaro, E.; Mavilio, D.; Di Vito, C. Targeting NKG2A to Elucidate Natural Killer Cell Ontogenesis and to Develop Novel Immune-Therapeutic Strategies in Cancer Therapy. J. Leukoc. Biol. 2019, 105, 1243-1251. [CrossRef]

355. Guillerey, C.; Huntington, N.D.; Smyth, M.J. Targeting Natural Killer Cells in Cancer Immunotherapy. Nat. Immunol. 2016, 17, 1025-1036. [CrossRef]

356. Alnaggar, M.; Lin, M.; Mesmar, A.; Liang, S.; Qaid, A.; Xu, K.; Chen, J.; Niu, L.; Yin, Z. Allogenic Natural Killer Cell Immunotherapy Combined with Irreversible Electroporation for Stage IV Hepatocellular Carcinoma: Survival Outcome. Cell Physiol. Biochem. 2018, 48, 1882-1893. [CrossRef]

357. Lin, M.; Alnaggar, M.; Liang, S.; Wang, X.; Liang, Y.; Zhang, M.; Chen, J.; Niu, L.; Xu, K. An Important Discovery on Combination of Irreversible Electroporation and Allogeneic Natural Killer Cell Immunotherapy for Unresectable Pancreatic Cancer. Oncotarget 2017, 8, 101795-101807. [CrossRef]

358. Li, L.; Li, W.; Wang, C.; Yan, X.; Wang, Y.; Niu, C.; Zhang, X.; Li, M.; Tian, H.; Yao, C.; et al. Adoptive Transfer of Natural Killer Cells in Combination with Chemotherapy Improves Outcomes of Patients with Locally Advanced Colon Carcinoma. Cytotherapy 2018, 20, 134-148. [CrossRef]

359. Ishikawa, T.; Okayama, T.; Sakamoto, N.; Ideno, M.; Oka, K.; Enoki, T.; Mineno, J.; Yoshida, N.; Katada, K.; Kamada, K.; et al. Phase I Clinical Trial of Adoptive Transfer of Expanded Natural Killer Cells in Combination with IGG1 Antibody in Patients with Gastric or Colorectal Cancer. Int. J. Cancer 2018, 142, 2599-2609. [CrossRef]

360. Schonfeld, K.; Sahm, C.; Zhang, C.; Naundorf, S.; Brendel, C.; Odendahl, M.; Nowakowska, P.; Bonig, H.; Kohl, U.; Kloess, S.; et al. Selective Inhibition of Tumor Growth by Clonal NK Cells Expressing an Erbb2/Her2-Specific Chimeric Antigen Receptor. Mol. Ther. 2015, 23, 330-338. [CrossRef]

361. Zhang, C.; Burger, M.C.; Jennewein, L.; Genssler, S.; Schonfeld, K.; Zeiner, P.; Hattingen, E.; Harter, P.N.; Mittelbronn, M.; Tonn, T.; et al. Erbb2/Her2-Specific NK Cells for Targeted Therapy of Glioblastoma. J. Natl. Cancer Inst. 2016, 108. [CrossRef]

362. Hanahan, D.; Weinberg, R.A. Hallmarks of Cancer: The Next Generation. Cell 2011, 144, 646-674. [CrossRef] [PubMed]

363. Valkenburg, K.C.; de Groot, A.E.; Pienta, K.J. Targeting the Tumour Stroma to Improve Cancer Therapy. Nat. Rev. Clin. Oncol. 2018, 15, 366-381. [CrossRef] [PubMed]

364. Ostermann, E.; Garin-Chesa, P.; Heider, K.H.; Kalat, M.; Lamche, H.; Puri, C.; Kerjaschki, D.; Rettig, W.J.; Adolf, G.R. Effective Immunoconjugate Therapy in Cancer Models Targeting a Serine Protease of Tumor Fibroblasts. Clin. Cancer Res. 2008, 14, 4584-4592. [CrossRef] [PubMed]

365. LeBeau, A.M.; Brennen, W.N.; Aggarwal, S.; Denmeade, S.R. Targeting the Cancer Stroma with a Fibroblast Activation Protein-Activated Promelittin Protoxin. Mol. Cancer Ther. 2009, 8, 1378-1386. [CrossRef] [PubMed]

366. Kakarla, S.; Chow, K.K.; Mata, M.; Shaffer, D.R.; Song, X.T.; Wu, M.F.; Liu, H.; Wang, L.L.; Rowley, D.R.; Pfizenmaier, K.; et al. Antitumor Effects of Chimeric Receptor Engineered Human T Cells Directed to Tumor Stroma. Mol. Ther. 2013, 21, 1611-1620. [CrossRef] [PubMed]

367. Wang, L.C.; Lo, A.; Scholler, J.; Sun, J.; Majumdar, R.S.; Kapoor, V.; Antzis, M.; Cotner, C.E.; Johnson, L.A.; Durham, A.C.; et al. Targeting Fibroblast Activation Protein in Tumor Stroma with Chimeric Antigen Receptor T Cells Can Inhibit Tumor Growth and Augment Host Immunity without Severe Toxicity. Cancer Immunol. Res. 2014, 2, 154-166. [CrossRef] [PubMed]

368. Loeffler, M.; Kruger, J.A.; Niethammer, A.G.; Reisfeld, R.A. Targeting Tumor-Associated Fibroblasts Improves Cancer Chemotherapy by Increasing Intratumoral Drug Uptake. J. Clin. Invest. 2006, 116, 1955-1962. [CrossRef] [PubMed]

369. Lo, A.; Wang, L.S.; Scholler, J.; Monslow, J.; Avery, D.; Newick, K.; O’Brien, S.; Evans, R.A.; Bajor, D.J.; Clendenin, C.; et al. Tumor-Promoting Desmoplasia Is Disrupted by Depleting FAP-Expressing Stromal Cells. Cancer Res. 2015, 75, 2800-2810. [CrossRef] 
370. Chen, M.; Xiang, R.; Wen, Y.; Xu, G.; Wang, C.; Luo, S.; Yin, T.; Wei, X.; Shao, B.; Liu, N.; et al. A Whole-Cell Tumor Vaccine Modified to Express Fibroblast Activation Protein Induces Antitumor Immunity against Both Tumor Cells and Cancer-Associated Fibroblasts. Sci. Rep. 2015, 5, 14421. [CrossRef]

371. Mariathasan, S.; Turley, S.J.; Nickles, D.; Castiglioni, A.; Yuen, K.; Wang, Y.; Kadel, E.E., III; Koeppen, H.; Astarita, J.L.; Cubas, R.; et al. TGFbeta Attenuates Tumour Response to PD-L1 Blockade by Contributing to Exclusion of T Cells. Nature 2018, 554, 544-548. [CrossRef]

372. Zhao, F.; Evans, K.; Xiao, C.; DeVito, N.; Theivanthiran, B.; Holtzhausen, A.; Siska, P.J.; Blobe, G.C.; Hanks, B.A. Stromal Fibroblasts Mediate Anti-PD-1 Resistance Via MMP-9 and Dictate TGF-beta Inhibitor Sequencing in Melanoma. Cancer Immunol. Res. 2018, 6, 1459-1471. [CrossRef] [PubMed]

373. Pure, E. Seeking Synergy of Checkpoint Blockade through TGF-beta Inhibition. Cancer Immunol. Res. 2018, 6, 1444. [CrossRef] [PubMed]

374. Ferrarelli, L.K. Combination Therapy Is a Game of Strategy. Sci. Signal. 2019, 12, eaaw5563. [CrossRef]

375. Sanmamed, M.F.; Carranza-Rua, O.; Alfaro, C.; Onate, C.; Martin-Algarra, S.; Perez, G.; Landazuri, S.F.; Gonzalez, A.; Gross, S.; Rodriguez, I.; et al. Serum Interleukin-8 Reflects Tumor Burden and Treatment Response across Malignancies of Multiple Tissue Origins. Clin. Cancer Res. 2014, 20, 5697-5707. [CrossRef] [PubMed]

376. Dranoff, G. Cytokines in Cancer Pathogenesis and Cancer Therapy. Nat. Rev. Cancer 2004, 4, 11-22. [CrossRef] [PubMed]

377. Del Vecchio, M.; Bajetta, E.; Canova, S.; Lotze, M.T.; Wesa, A.; Parmiani, G.; Anichini, A. Interleukin-12: Biological Properties and Clinical Application. Clin. Cancer Res. 2007, 13, 4677-4685. [CrossRef] [PubMed]

378. Charych, D.H.; Hoch, U.; Langowski, J.L.; Lee, S.R.; Addepalli, M.K.; Kirk, P.B.; Sheng, D.; Liu, X.; Sims, P.W.; VanderVeen, L.A.; et al. NKTR-214, an Engineered Cytokine with Biased IL2 Receptor Binding, Increased Tumor Exposure, and Marked Efficacy in Mouse Tumor Models. Clin. Cancer Res. 2016, 22, 680-690. [CrossRef]

379. Steele, C.W.; Karim, S.A.; Leach, J.D.G.; Bailey, P.; Upstill-Goddard, R.; Rishi, L.; Foth, M.; Bryson, S.; McDaid, K.; Wilson, Z.; et al. CXCR2 Inhibition Profoundly Suppresses Metastases and Augments Immunotherapy in Pancreatic Ductal Adenocarcinoma. Cancer Cell 2016, 29, 832-845. [CrossRef]

380. Ries, C.H.; Cannarile, M.A.; Hoves, S.; Benz, J.; Wartha, K.; Runza, V.; Rey-Giraud, F.; Pradel, L.P.; Feuerhake, F.; Klaman, I.; et al. Targeting Tumor-Associated Macrophages with Anti-CSF-1R Antibody Reveals a Strategy for Cancer Therapy. Cancer Cell 2014, 25, 846-859. [CrossRef]

381. Zhao, Q. Dual Targeting of CCR2 and CCR5: Therapeutic Potential for Immunologic and Cardiovascular Diseases. J. Leukoc. Biol. 2010, 88, 41-55. [CrossRef]

382. Neubert, N.J.; Schmittnaegel, M.; Bordry, N.; Nassiri, S.; Wald, N.; Martignier, C.; Tille, L.; Homicsko, K.; Damsky, W.; Maby-El Hajjami, H.; et al. T Cell-Induced CSF1 Promotes Melanoma Resistance to Pd1 Blockade. Sci. Transl. Med. 2018, 10, eaan3311. [CrossRef] [PubMed]

(C) 2019 by the authors. Licensee MDPI, Basel, Switzerland. This article is an open access article distributed under the terms and conditions of the Creative Commons Attribution (CC BY) license (http://creativecommons.org/licenses/by/4.0/). 